2008

\title{
Benefits from Private Antitrust Enforcement: Forty Individual Case Studies
}

Robert H. Lande

University of Baltimore School of Law, rlande@ubalt.edu

Joshua P. Davis

University of San Francisco, davisj@usfca.edu

Follow this and additional works at: http://scholarworks.law.ubalt.edu/all_fac

Part of the Antitrust and Trade Regulation Commons

\section{Recommended Citation}

Benefits from Private Antitrust Enforcement: Forty Individual Case Studies, Univ. of San Francisco Law Research Paper No. 2011-22

This Article is brought to you for free and open access by the Faculty Scholarship at ScholarWorks@University of Baltimore School of Law. It has been accepted for inclusion in All Faculty Scholarship by an authorized administrator of ScholarWorks@University of Baltimore School of Law. For more information, please contact snolan@ubalt.edu. 


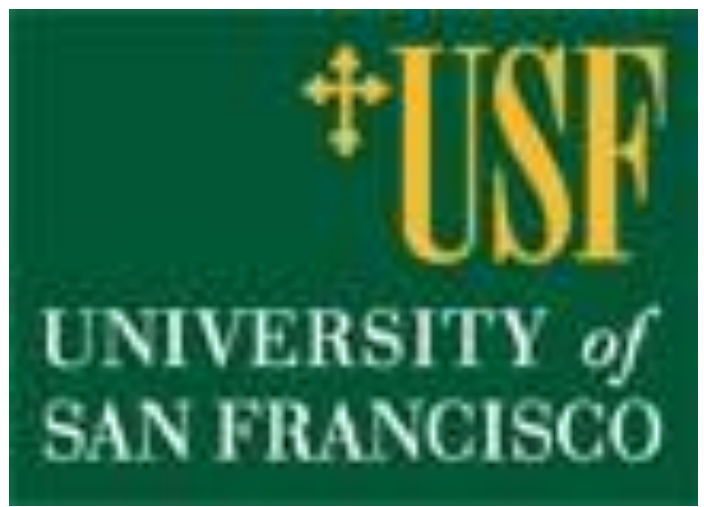

\section{University of San Francisco School of Law}

University of San Francisco Law Research Paper No. 2011-22

\section{BENEFITS FROM PRIVATE ANTITRUST ENFORCEMENT: FORTY INDIVIDUAL CASE STUDIES}

Robert H. Lande \& Joshua P. Davis 
Benefits from Antitrust Private Antitrust Enforcement: Forty Individual Case Studies

\author{
Robert Lande and Joshua Davis ${ }^{1}$
}

This Paper presents information about forty of the

largest recent successful private antitrust cases. To do

this, the paper gathers information about each case,

including, inter alia, (1) the amount of money each action

recovered for the victims of each alleged antitrust violation,

(2) what proportion of the money was recovered from foreign

entities, (3) whether government action preceded the private

litigation, (4) the attorney's fees awarded to plaintiffs'

counsel, (5) on whose behalf money was recovered (direct

purchasers, indirect purchasers, or a competitor), and (6) the

kind of claim the plaintiffs asserted (rule of reason, per se,

1 The authors are, respectively: Venable Professor of Law at the University of Baltimore School of Law and a Director of the American Antitrust Institute; and Professor of Law and Director, Center for Law and Ethics at the University of San Francisco School of Law and a member of the Advisory Board of the American Antitrust Institute. They are grateful to the American Antitrust Institute ("AAI") for assisting with and supporting this project in numerous ways. However, all conclusions in this study are solely those of the authors and are not necessarily those of the AAI.

The authors are also grateful to Morgan Anderson, Erin Bennett, Maarten Burggraaf, Stratis Camatsos, Jonathan Cuneo, Gene Crew, Erika Dahlstrom, Michael Einhorn, Mike Freed, Bobby Gordon, Norm Hawker, Gabrielle Hunter, Richard Kilsheimer, Ruthie Linzer, Phyra McCandless, Polina Melamed, Joey Pulver, Brian Ratner, Doug Richards, Tara Shoemaker, Andrew Smullian and Drew stevens for researching and writing drafts of the individual case studies. The authors also thank Richard Brunell, John Connor, Eric Cramer, Albert Foer, Jonathan Jacobson, Carl Lundgren, Dan small and members of the private bar too numerous to mention for information about individual cases and for comments on earlier versions of this study. The authors are grateful for excellent research assistance by Erika Dahlstrom and Joey Pulver. 
or a combination of the two). A separate study, forthcoming in the U.S.F. Law Review, aggregates and analyzes this

information. That study also compares the total monetary amounts paid in all forty cases, as well as from the subset of the forty cases that also resulted in criminal penalties, to the total criminal antitrust fines imposed during the same period by the United States Department of Justice ("DOJ"), and also to the deterrence effects of the prison sentences that resulted from DOJ prosecutions during this period. The overall goal of the project is to take a first step toward providing an empirical basis for assessing whether private enforcement of the antitrust laws serves its intended purposes and is in the public interest.

The results of the study show that private antitrust enforcement helps the economy in many ways. It very significantly compensates victims of illegal corporate behavior, and is almost always the only way they can receive redress. Private enforcement often prevents foreign corporations from keeping the many billions of dollars they illegally obtain from individual and corporate purchasers in the United States. The Study also shows that almost half of the underlying violations were first uncovered by private attorneys, not government enforcers, and that litigation in many other cases had a mixed public/private origin. The 
evidence also shows that private litigation probably does more to deter antitrust violations than all the fines and incarceration imposed as a result of criminal enforcement by the U.S. Department of Justice. This is one of the most surprising results from our study. We do not know of any past study that has documented that private enforcement has such a significant deterrence effect as compared to DOJ criminal enforcement. 
Cases Studied:

1. In Re Airline Ticket Commission Litigation, 1996 U.S. Dist. LEXIS 20361; 1996-2 Trade Cas. (CCH) P71, 552

2. In re Auction Houses Antitrust Litig., 164 F. Supp. 2d 345 (S.D.N.Y. 2001), aff'd, 2002 U.S. App. LEXIS 15327(2d Cir. 2002) and Kruman V. Christie's International PLC, 284 F.3d 384 (2d Cir. 2002).

3. Augmentin. Ryan-House et al v. GlaxoSmithKline plc, C.A. Doc. No. 2:02Cv442 (E.D.Va. 2004); SAJ Distributors, Inc. and Stephen L. LaFrance Holdings, Inc. V. SmithKline Beecham Corp, Doc. No. 2:04CV23

4. In re Automotive Refinishing Paint Antitrust Litigation, 177 F. Supp. 2d 1378 (E.D. Pa. Nov. 15, 2001).

5. In re: Buspirone Antitrust Litigation, 185 F. Supp. 2d 340 (S.D.N.Y. 2002) MDL Doc. No. 1413, and In re Buspirone Patent Litigation, 185 F. Supp.2d 363 (S.D.N.Y. 2002). Final

Settlement approval at ( 2003 U.S. Dist. Lexis 25638, April 17, 2003 ). (Buspar)

6. Caldera, Inc. V. Microsoft Corp., Case No. 2:96CV645B, 72 F.Supp.2d 1295 (D. Utah 1999).

7. In re: Cardizem CD Antitrust Litigation, MDL Docket No. 1278; 105 F. Supp 2d 682 (E. Dist. Mich. 2000); 332 F.3d 896 $\left(6^{\text {th }} \operatorname{Cir} .2003\right)$.

8. In re: Citric Acid Antitrust Litigation, MDL Docket No. 1092 ; 996 F. Supp. 951 (N. Dist. Cal. 1998).

9. In re Commercial Explosives Litigation, 945 F. Supp. 1489 (D. Utah 1996).

10. Conwood Co. V. United States Tobacco Co., 290 F.3d 768 (6 th $^{\text {th }}$ Cir. 2002).

11. In re Dynamic Random Access Memory (DRAM) Antitrust Litigation, Master File No. M-02-1486PJH, MDL No. 1486.

12. Natural Gas Antitrust Cases I, II, III \& IV. Sweetie's, V. El Paso Corporation, No. 319840 (S.F. Super. Ct.); Continental Forge Company $v$. Southern California Gas Co., No. BC237336 (L.A. Super. Ct.); Berg V. Southern California Gas 
Co., No. BC241951 (L.A. Super. Ct.); City of Long Beach V. Southern California Gas Co., No. BC247114 (L.A. Super. Ct.); City of L.A. V. Southern California Gas Col, No. BC265905 (L.A. Super. Ct.); Phillip V. El Paso Merchant Energy LP, No. GIC 759425 (San Diego Super. Ct.); and Phillip V. El Paso Merchant Energy LP, No. GIC 759426 (San Diego Super. Ct.). (El Paso)

13. In re Flat Glass Antitrust Litigation, MDL 1200, Master Docket Misc. 97-0550 (W.D. Pa.)

14. In Re: Fructose Antitrust Litigation, M.D.L. File 1087, Master File \# 94-1577 (Michael Mihm) (C.D.Ill. 1995)

15. IN RE: Graphite Electrodes Antitrust Litigation, 2003 WL 22358491 (E.D. Pa. 2003)

16. IBM V. Microsoft (complaint apparently not filed)

17. In Re: Insurance Antitrust Litigation, 723 F. Supp. 464 (N.D. CA 19989); reversed, 938 F. 2d 919 (9th Cir. 1991); affirmed sub nom Hartford Ins. Co. V. California, 509 U.S. 764 (1993).

18. In re Linerboard Antitrust Litig., MDL No. 1261, 2000 WL 1475559, at *1-3 (E.D.Pa. Oct.4, 2000) ("Linerboard I" ); In re Linerboard Antitrust Litig., 203 F.R.D. 197, 201-04

(E.D.Pa.2001) ("Linerboard II"); In re Linerboard Antitrust Litig., 305 F.3d 145, 147-49 (3d Cir.2002) ("Linerboard III"); In re Linerboard Antitrust Litig., 321 F.Supp 2d 619 (E.D. Pa. 2004 ).

19. In re Amino Acid Lysine Antitrust Litigation, MDL No. 1083, 918 F. Supp. 1190 .

20. In re: Microcrystalline Cellulose Antitrust Litigation, MDL No 1402

21. In Re: NASDAQ Market-Makers Antitrust Litigation, M.D.L. No, 1023, No. 94 Civ. 3996 (RWS) (S.D.N.Y. 1998).

22. Law V. National Collegiate Athletic Ass'n., 902 F.Supp. 1394 (D.Kan. 1995); affirmed, 134 F. 3d 1010 (10 th Cir. 1998); reversed, 938 F. 2d 919 (9th Cir. 1991). 
23. Netscape Comm. Corp. v. Microsoft Corp., Per Local Civil Rule 40.5, Related to Civil Action Nos. 98-1232 and 98-1233 (D.D.C. 2002) (a/k/a AOL v. Microsoft).

24. North Shore Hematology \& Oncology Associates V. BristolMyers Squibb Co., Civil Action No.:04 CV248(EGS) (2004) (Platinol)

25. In re Lease Oil Antitrust Litigation (No. II), 186 F.R.D. 403 (S .D. Tex. 1999), 142 Oil \& Gas Rep. 532 (1999)

26. Oncology \& Radiation Associates V. Bristol-Meyers Squibb Co., Case No. 1:04CV00248 (D.D.C.) (Taxol).

27. Stop $N$ Shop Supermarket Company, et. al.V. Smithkline Beecham Corp. Civil Action No. $03-C V-4578$ (E.D. Pa. 2005), and; Nichols V. SmithKline Beecham Corp., No. 00-CV-6222 (E.D. Pa.2005) (Paxil)

28. In Re: Polypropylene Carpet Antitrust Litigation, 93 F. Supp. 2d 1348 (N.D. Ga. 2000).

29. RealNetworks, Inc. v. Microsoft Corp., Civil Action No. JFM-04-968, MDL Docket No. 1332 (D. Md.) (2005 settlement)

30. Red Eagle Resources, et al. v. Baker Hughes Inc., et al., No. 4:91Cv00627 (Docket) (S.D.Tex. Mar. 11, 1991)(In re Drill Bits Antitrust Litigation)

31. In re Relafen Antitrust Litigation, Civil Action No. 0112239-WGY; 346 F. Supp. 2d 349 (D. Mass. 2004)；231 F.R.D. 52 (D. Mass. 2005 ).

32. In re: Remeron Antitrust Litigation, 2005 U.S. Dist. Lexis 27013 (D.N.J. 2005 ).

33. In Re Rubber Chemicals Antitrust Litigation, 350 F.Supp.2d 1366, 2005-1 Trade Cases P 74,804 (Jud.Pan.Mult.Lit. Dec. 21, 2004 ( (No. MDL 1648).

34. In re Sorbates Direct Purchaser Antitrust Litigation, Not Reported in F.Supp.2d, 2002 WL 31655191 (N.D. Cal.)

35. Sun Microsystems V. Microsoft, 333 F.3d 517 (4 ${ }^{\text {th }}$ Cir. $2003)$. 
36. In Re: Terazosin Hydrochloride Antitrust Litigation Case No. 99-MDL-1317-Seitz/Klein, a/k/a Louisiana Wholesale Drug Co., Inc. V. Abbot Laboratories, et al. S.D. Fla Case no. 983125 and Valley Drug Co. V. Abbot Laboratories, et al. S.D. Fla. Case No. 99-7143.

37. Transamerican Refining Corp. v. Dravo Corp., et al., No. 4:88CV00789 (Docket) (S.D.Tex. Mar. 10, 1988) (Specialty steel Piping Antitrust Litigation) (1992 settlement)

38. In re: Urethane Antitrust Litigation, MDL No. 1616, 232 F.R.D. 681 (D. Kan. 2005).

39. In Re: Visa Check/MasterMoney Antitrust Litigation, a/k/a Wal-Mart Stores, Inc. et. al V. Visa U.S.A. Inc. and MasterCard International Inc., 396 F. 3d 96, 114 (2d Cir. $2005)$.

40. In re Vitamins Antitrust Litigation (many related cases) 
1. In Re Airline Ticket Commission Litigation, 1996 U.S. Dist. LEXIS 20361; 1996-2 Trade Cas. (CCH) P71, 552

This case is notable because: 1: This parties settled this case for \$86.1 million; 2: The Court ordered the Defendants to pay 75\% of the Plaintiffs' discovery costs, related to the Defendants' "passing on" defense; 3: The Court awarded plaintiffs' counsel one-third of the settlement due to their skill and effort.

The American Society of Travel Agents (ASTA) sued seven major airlines, including TWA, Continental, USAir, American Airlines, Delta, Northwest, and United Airlines; for violations of Section I and II of the Sherman Act. ${ }^{2}$

According ASTA, the anticompetitive conduct occurred when the airlines imposed an industry-wide cap on the commissions they paid to travel agents. ${ }^{3}$ At the time of the suit, the defendants comprised about $85 \%$ of domestic flights in the United States. ${ }^{4}$

2 Price Fixing: Cy Pres Distribution Must Be More Closely Related to Airline Commission Cap Litigation Antitrust Trade \& Regulation Daily (October 22, 2001).

3 The airlines were charged with "conspiring to reduce commissions on ticket sales by travel agents from $10 \%$ to a maximum of $\$ 50$ for round-trip domestic flights and $\$ 25$ for a one-way ticket". Preliminary Okay Is Given to \$86 Million Settlement of Litigation By Travel Agents BNA Antitrust \& Trade Regulation Daily (September 24, 1996). 4 In Re Airline Ticket Commission Antitrust Litigation, 898 F.Supp. 685, 687 (D.Minn. 1995). 
Prior to the caps, airlines paid travel agents a commission based on the ticket price. ${ }^{5}$ Delta was first to announce a cap on the commissions. ${ }^{6}$ Following this announcement, the other six major airlines implemented caps in less than a week. ${ }^{7}$ The plaintiffs argued that it didn't make economic sense for the airlines to all impose commission caps. ${ }^{8}$ When the parties settled, the airlines agreed to pay ASTA for the anticompetitive conduct that occurred from February 1995 to September $1995 .^{9}$

This case first made news when Judge Rosenbaum ruled on the defendants' request to take discovery pertaining to the "passing on defense" that was denied in Hanover Shoe. ${ }^{10}$ The defendants sought discovery regarding damages, or the lack

5 The travel agents claimed that, since 1960, the airlines paid 10\% of the ticket price. In Re Travel Agency Commission Antitrust Litigation, 898 F.Supp. 685, 687 (D.Minn. 1995).

6 Id. at 687 .

7 Id. at 687 .

8 "(Plaintiffs) assert that, in an open and competitive environment, an airline which declined to cut commissions would benefit because travel agents would favor higher paying airlines". Id. at 688 .

9 Monetary Settlement of Airline Ticket Commission Gets Final Okay, BNA Antitrust \& Trade Regulation Daily (Feb. 10, 1997). 10 Airlines May Engage In Some Discovery To Support Impermissible Pass-On Defense, BNA Antitrust \& Trade Regulation Daily (April 3, 1996). 
thereof, suffered by the plaintiffs as a result of the caps. ${ }^{11}$ The defendants reasoned that travel agents were not harmed by the caps because they could still make money from booking nonflight travel, such as cruises. ${ }^{12}$ Although Judge Rosenbaum reluctantly granted the defendants' request, he noted that the defendants' contentions were "unusual" and "most conjectural". ${ }^{13}$ Due to the questionable nature of the discovery, the defendants were ordered to pay 75\% of the plaintiffs' costs in producing the discovery. ${ }^{14}$ Furthermore, the judge warned the defendants that "if the proffered discovery is rejected both at trial and appeal, the court may also consider assessing defendants with the remaining $25 \%$ of the plaintiffs' survey cost" ${ }^{15}$

11 Id.

12 In Re Airline Commission Antitrust Litigation, 918 F.Supp. 283, 287 (D. Minn. 1996).

13 Airlines May Engage In Some Discovery To Support Impermissible Pass-On Defense, BNA Antitrust \& Trade Regulation Daily (April 3, 1996).

14 Id.

15 Id. 
The settlement totaled $\$ 86.1$ million dollars. ${ }^{16}$ Only an approximate $0.5 \%$ of the class objected to the settlement. ${ }^{17}$ The Court awarded plaintiffs' counsel the full amount they asked for, one-third of the settlement. ${ }^{18}$ The Court noted that plaintiffs" counsel "reasonably assessed the value of the case"...in order to reach a settlement that is "cost-effective, simple, and fundamentally fair" to members of the class. ${ }^{19}$

Noting the absence of a "smoking gun", and the existence of an "oligoplistic market" where "rapid price coalescence is the norm", plaintiffs' counsel "personally financed the case, incurring expenses exceeding $\$ 3$ million with no guarantee of an ultimate recovery" ${ }^{20}$

In addition to the resources invested in the case, the Court also highlighted the fact that plaintiffs' counsel

16 TWA was the first defendant to settle. Continental settled for $\$ 4.25$ million, and USAir paid \$9.81 million. The remaining four airlines settled with the class on the day trial was to begin, in which American Airlines paid \$21.32 million, Delta paid $\$ 20.3$ million, Northwest paid $\$ 10.87$ million, and United Airlines paid \$19.51 million. Monetary Settlement of Airline Ticket Commission Litigation Gets Final Okay, BNA Antitrust \& Trade Regulation Daily (February 10, 1997).

17 Id.

18 Id.

19 Id.

20 Id. 
"underwent difficult and protracted settlement negotiations while simultaneously preparing for trial. This work required time, expense, and great skill, all to the class's benefit". ${ }^{21}$

After the settlement funds were distributed to travel agents, about $\$ 600,000.00$ remained unclaimed. ${ }^{22}$ The plaintiffs proposed that the funds should be distributed to travel agents in Puerto Rico and the Virgin Islands, because they were harmed by the same anticompetitive conduct. ${ }^{23}$ Instead, the Court awarded the funds to several law schools and charities in Minnesota, where the litigation was filed. ${ }^{24}$ After an appeal, the court awarded the funds to the travel agents, stating that these agents were "clearly the next best recipients of the funds". ${ }^{25}$

$21 \quad I d$.

22 Cy Pres Award of Settlement Must Be Tailored To Goals of Underlying Suit, United States Law Week (October 15, 2002). http: //pub.bna.com/lw/021639.pdf

23 Id.

$24 \quad I d$.

25 Id. 
In re Auction Houses Antitrust Litig., 164 F. Supp. 2d 345 (S.D.N.Y. 2001), aff'd, 2002 U.S. App. LEXIS 15327 (2d Cir. 2002 ) and Kruman V. Christie's International PLC, 284 F.3d 384 (2d Cir. 2002).

These cases are outstanding examples of the successful outcome of a private antitrust class action for many reasons: 1. The aggregate amount of the combined recoveries in the cases includes $\$ 412$ million in cash and $\$ 100$ million in discount certificates (in the class action involving domestic auctions), and $\$ 40$ million in cash (in the class action involving foreign auctions), for a total recovery of $\$ 552$ million. 2. The vast majority of the settlement was obtained by U.S. businesses and consumers from the foreign defendants. 3. The domestic portion of the settlement was found by the court to represent "perhaps 1.8 times to 4.0 times the damages" suffered by the domestic class. ${ }^{26} 4$. Counsel in the domestic case received legal fees that were approximately $80 \%$

26 The foreign portion of the settlement represented a much smaller proportion of potential damages, but was substantially discounted for risks stemming from legal weaknesses in the claims, including the basic legal weakness subsequently demonstrated by the supreme Court's decision two years later, in Empagran, S.A. V. F. Hoffman-LaRoche Ltd., 542 U.S. 155 (2004), under which the foreign class would have had no viable claims under United States law. 
cash and $20 \%$ discount coupons, the same ratio as the overall cash/coupon ratio in the settlement. 5. The legal fees represented only $5.2 \%$ of the total settlement. 6 . If the coupons are not used after 5 years, they can be redeemed for their face value in cash.

In the late 1990s, the Department of Justice ("DOJ") initiated an investigation into the possibility that parallel increases in the amounts of commissions charged by Christie's and Sotheby's to both buyers and sellers may have been the result of a conspiracy. That investigation seemed to stall until, in late 1999, counsel for Christie's came into the possession of handwritten notes made by CEO Christopher Davidge of Christie's, which clearly reflected conspiratorial communications between the defendants. In January 2000, Christie's sought and obtained amnesty from DOJ. In the ensuing weeks, many class actions were commenced on behalf of buyers and sellers at domestic auctions under United states antitrust law. Those class actions were consolidated in the Southern District of New York before Judge Lewis A. Kaplan. In view of the clear evidence of conspiracy and Christie's amnesty commitments, Judge Kaplan took the unusual step of holding an auction for the position of lead counsel. The winning bid in that auction was submitted by David Boies, who 
agreed to undertake representation of the class on the unusual and risky basis that his firm would receive 25 percent of any recovery in the case in excess of $\$ 405$ million. However, Boies elected not to include claims based on foreign auctions among the class claims, believing that such claims were not viable under United States law. In October 2000, after only approximately four months of further litigation, a settlement of the domestic class action for the amount of $\$ 412$ million in cash and $\$ 100$ million in discount certificates was first documented and proposed to the District Court. In the interim, the separate Kruman class action had been commenced by other class counsel on behalf of the purchasers and sellers at foreign auctions who had been excluded from the class in the action led by Boies. Initially, it was proposed to the court in the domestic class action that to the extent such foreign auction claims were held by persons who were also domestic class members, they would be released as part of the domestic settlement. The effect of such a release would have been significantly to undercut the separate class action on behalf of customers at foreign auctions, since many if not most auction customers buy or sell at auctions both inside and outside the United States. However, the District Court invalidated that aspect of the proposed releases in a series of rulings in early 2001, finding that in 
proposing to release the claims based on foreign auctions for no additional consideration, Boies had had a "structural conflict of interest." 27 Those rulings by the District Court invalidating the proposed release of foreign claims were later affirmed by the second Circuit in 2002. However, in response to the District Court's initial invalidation of the releases, the parties had modified their settlement to provide that in the event the second Circuit affirmed the invalidation of the releases, the settlement would continue to be final and effective. Thus, the invalidation of the initially proposed releases of claims arising from foreign auctions ultimately did not derail the domestic settlement.

Thereafter, in 2003, the class of buyers and sellers at foreign auctions also was able to negotiate its separate settlement in the amount of an additional \$40 million in cash, in the wake of their success, in Kruman v. Christie's International PLC, 284 F.3d 384 (2d Cir. 2002), in establishing the legal viability of the class claims arising from foreign auctions. By the time of that 2003 settlement, testimony and evidence emerging in the criminal trial of Alfred Taubman of Sotheby's during 2003 (the government's criminal case resulted in a \$45 million fine and jail for at

27 Error! Main Document Only. In re Auction House Antitrust Litigation, 42 Fed. Appx. 511, 516 (2002). 
least one defendant ${ }^{28}$ had cast substantial doubt on the existence of any conspiracy between the defendants with regard to buyer's premiums charged by the defendants, as distinguished from seller's commissions. In addition, looming over the case was the strong possibility that the Supreme Court might take certiorari and reverse the second Circuit's decision upholding rights of customers at foreign auctions to bring claims arising from the foreign auctions under United States antitrust law. Those two risks were the primary reason why less consideration was obtained for the class of foreign auction customers. Indeed, after the $\$ 40$ million foreign auction settlement had been reached and approved by the court, the Supreme Court did take certiorari and reverse a D.C. Circuit ruling that had followed the decision in Kruman, in Empagran. Thus, the $\$ 40$ million foreign auction settlement may be the only substantial settlement of its kind that ever will occur, based on United States antitrust law claims arising entirely from foreign transactions.

The coupons in the domestic case might have been the best coupons ever issued in an antitrust case. Valued at \$100 million by the Court, they had a face value of \$125 million

28 Scott D. Hammond, An Overview of Recent Developments In The Antitrust Division's Criminal Enforcement Program, Address Before the American Bar Association (Jan. 10, 2005), available at http://www.usdoj.gov/atr/public/speeches/207226.pdf, Pg. 11 . 
when issued. ${ }^{29}$ They were and are fully transferable, and they do trade. All unused coupons can be redeemed for face value after 5 years (in May 2007). Counsel took approximately 20\% of their fees in these coupons.

29 Id. at 520 . 
Augmentin. Ryan-House et al v. GlaxoSmithKline plc, C.A. Doc. No. 2:02CV442 (E.D.Va. 2004); SAJ Distributors, Inc. and Stephen L. LaFrance Holdings, Inc. V. SmithKline Beecham Corp, DoC. No. 2:04Cv23

This case is notable because (1) it produced substantial recoveries for both direct and indirect purchasers; of $\$ 62.5$ million and \$29 million respectively, all from a foreign corporation; (2) this case only involved section 2 of the Sherman Act; (3) Class counsel asked for and was awarded 20\% of the recovery in the direct action, and $25 \%$ in the indirect action; (4) there was no prior federal prosecution of the antitrust violations at issue; ${ }^{30}$ and (5) there were later state actions with participation from the US Department of Justice. GSK allegedly using invalid patents to prevent entry of generic products. As stated in GSK's 2004 Annual Report: ${ }^{31}$

In 2002, the US District Court for the Eastern District of Virginia found various patents covering Augmentin invalid. That holding was subsequently affirmed by the [Court of Appeals for the Federal Circuit]. Following the adverse trial court decision, purported anti-trust class actions were filed on behalf

30 SAJ Distributors, Inc. and Stephen L. LaFrance Holdings, Inc. v. SmithKline Beecham Corp, Doc. No. 2:04cv23, Memorandum in Support of Class Counsel's Motion for Award of Attorney Fees and Reimbursement of Expenses, page 4 (E.D. Va., 2004), [hereinafter "Fee Memo"]. ("There was no prior investigation from the Department of Justice or Federal Trade Commission complaint against GSK.")

31 GSK Form 20-F 03-2004, Annual report pursuant to section 13 or $15(d)$ of the Securities Exchange Act of 1934 For the fiscal year ended December 31, 2004; Commission file number 1-15170, page 121 [hereinafter "20-F, 2004"]. 
of classes of direct and indirect purchasers that were ultimately consolidated in the US District Court for the Eastern District of Virginia. Plaintiffs alleged that the Group knowingly obtained invalid patents and engaged in other anticompetitive conduct to prevent entry of generic products in violation of the monopolization section of the US anti-trust laws. The court has approved the Group's settlement of those class action claims.

Plaintiffs were a class of "All persons or entities in the United States that purchased Augmentin directly from GSK at any time from January 1, 2000 through April 30, 2004 (hereinafter the "Class Period"), except for governmental entities, GSK, its officers, directors, and subsidiaries, which are expressly excluded." ${ }^{32}$ The Class Counsel for the Direct Purchaser Plaintiffs ("Class Counsel") alleged a section 2 monopolization $\mathrm{claim}^{33}$ involving IP and patent law as well as the Hatch-Waxman Act. ${ }^{34}$

The Class Counsel were able to negotiate a settlement with the defendants during the discovery and pre-trial phase of the case. Many of the vital facts of this case were the subject of motions for summary judgment in related cases. ${ }^{35}$

\footnotetext{
32 Final order at 2 .

33 Fee Memo at 4 .

34 Id. at 22 .

35 See Geneva Pharmaceuticals, Inc. V. GlaxoSmithKline PLC, 349 F.3d 1373 (2003); Geneva Pharmaceuticals, Inc. V. GlaxoSmithKline PLC, 213 F. Supp.2d 597 (2002) Geneva
} 
Class counsel retained patent and economic experts to analyze liability and damages. ${ }^{36}$ This settlement was obtained despite the fact that, as the Court described, "GSK had significant defenses which the Class would need to overcome if the case went to trial." ${ }^{37}$

In September 2004 the Class Counsel filed a Motion for Award of Attorney Fees which described the risks they encountered in litigating this case, the difficulty of the case, and the extraordinary amount they were able to negotiate for. Class Counsel explained that this was a section 2 monopolization claim, which is more difficult to litigate than a per se violation of the Sherman Act. ${ }^{38}$ Next, Class Counsel explained that this was not a follow-on case; there was no prior federal antitrust action, no DOJ investigation, no FTC complaint. ${ }^{39}$ There were, however, other similar cases filed against GSK. ${ }^{40}$

Pharmaceuticals, Inc. V. GlaxoSmithKline PLC, 189 F.Supp.2d 377 (2002).

36 Final Order at 4.

37 Id.

38 Fee Memo at 3 .

39 Id. at 4.

40 See 20F, 2004. 
In the preceding cases finding certain Augmentin patents invalid, there was no court finding of fraud, which would require that Class Counsel prove fraud themselves as an element of their case. ${ }^{41}$ Class Counsel pointed out that damages would be difficult to prove because there could be factors other than anticompetitive behavior causing a delay in generic products reaching the market. ${ }^{42}$ Another risk was unfavorable law in the $11^{\text {th }}$ Circuit, where a similar class had been decertified. ${ }^{43}$ In light of these factors Class Counsel asked the Court to award a fee percentage of the settlement fund, rather than use the "lodestar" method of calculating fees.

The Direct Purchaser Class Plaintiffs, SAJ Distributors and Stephen L. LaFrance Holdings, Inc ("Plaintiffs") as well as approximately 70 class members ${ }^{44}$ reached a settlement Agreement with foreign company GlaxoSmithKline plc and SmithKline Beecham Corp ("GSK") and in July 2004, GSK deposited \$62.5 million into a Direct Purchaser settlement

\footnotetext{
41 Fee Memo at 4.

42 Id.

43 Id. at 4-5.

44 Fee Memo at 22.
} 
Fund Account. ${ }^{45}$ The Court found this amount "fair and reasonable and fully justified," ${ }^{46}$ saying that class counsel for the plaintiffs ("Class Counsel") vigorously and effectively pursued class members' claims. ${ }^{47}$ There was also an indirect purchaser class action on behalf of insurers and consumers. ${ }^{48}$ There, Counsel were awarded 25\% of a \$29 million recovery. ${ }^{49}$

45 SAJ Distributors, Inc. and Stephen L. LaFrance Holdings, Inc. v. SmithKline Beecham Corp, Doc. No. 2:04cv23, Final Settlement Approval Order, page 6, (E.D. Va., 2004), [hereinafter "Final Order"].

46 Id. at 10 .

47 Id. at 9 .

48 See In re Remeron End-Payor Antitrust Litigation, Not Reported in F.Supp.2d, 2005 WL 2230314 (D.N.J.), page 10 ("Mr. Meltzer was appointed Co-Lead Counsel in Ryan-House $v$. GlaxoSmithKline plc, C.A. 2:02cv442 (E.D.Va.), a pharmaceutical antitrust class action brought on behalf of end payors of the prescription medication Augmentin which recently settled for \$29 million");

also see e.g.

http://www.amc.gov/commission_hearings/pdf/Gustafson.pdf however, most citations point to www.augmentinlitigation.com, and that cite is no longer available.

49 See page 3 (HTML page 5) of AAI, The American, Antitrust Institute, AAI Working Paper No. 06-05, ABSTRACT: Indirect Purchaser Class Action Settlements, Author: Patrick E. Cafferty, Miller Faucher and Cafferty LLP. Though the pdf file cannot be found at the listed address, ( http://www.antitrustinstitute.org/recent2/510.pdf), it can be viewed in its HTML form:

http: / / www.google. com/search? q=cache : h6GrQtZnFRIJ : www . antitrus tinstitute.org/recent2/510.pdf+indirect+purchaser+augmentin+an titrust $\& h l=e n \& c t=c l n k \& c d=4 \& g l=u s$. 
Following the initiation of this private action, states took action with participation from the U.S. Department of Justice. In October of 2004, in West Virigina ex rel. McGraw v. GlaxoSmithKline, $P L C$ et al, Attorney General Darrell McGraw filed a lawsuit and consent order to settle the lawsuit against manufacturers GlaxoSmithKline, PLC, and SmithKline Beechham Corporation. The state alleged that the defendants had unlawfully attempted to extend their patent protection for the Paxil, Augmentin, and Relafen. After an investigation, with participation from the US Department of justice, ${ }^{50}$ and prior to filing the complaint, the state reached an agreement with the defendants to settle the manner. Under the terms of the settlement, the state received $\$ 500,000.00 .{ }^{51}$

Following that, states initiated the class action, In the Matter of GlaxoSmithKline, PLC (Augmentin) in 2005 with New York and Ohio as lead plaintiffs on behalf of states nationwide. ${ }^{52}$ An investigation was conducted and in 2006 a

50 http://www.naag.org/antitrust/search/viewCivil Litigation.php?trans_id=111

51 http: //www.wvs.state.wv.us/wvag/annualreports/2 004 annual report.pdf

52 http://www. naag.org/antitrust/search/viewCivilLitigation. php?trans_id=458. Also see Washington Medicaid to Receive Share of $\$ 3.5$ Million Settlement with Augmentin Manufacturer, US state News, Copyright 2006 US Fed News (HT Syndication), 
\$3.5 million multistate settlement was entered into by the participating states and GlaxosmithKline. ${ }^{53}$

April 12, 2006, 2006 WLNR 6392719; Attorney General Petro Secures Antitrust settlement Against Drug Maker, Us state News, Copyright 2006 US Fed News (HT Syndication), July 19, 2006,2006 WLNR 12481907;

53 Id. 
In re Automotive Refinishing Paint Antitrust Litigation, 177 F. Supp. 2d 1378 (E.D. Pa. Nov. 15, 2001).

These cases are noteworthy because: 1. they contain allegations of conspiring to fix, raise, maintain and stabilize prices, per se rule violations ${ }^{54}$; 2 . class counsel obtained a cash settlement of $\$ 105.75$ million $^{55} ; 3$. two of these defendants were foreign manufacturers ${ }^{56}$ who paid a total of $\$ 30.75$ million to American purchasers; ${ }^{57} 4$. these cases followed a government investigation, but that investigation was closed by the government without any indictments. ${ }^{58}$ Counsel requested and was awarded a 32\% attorneys' fee.

In March 2001, the auto body trade publication "Hammer and Dolly" published an article exposing a Department of Justice grand jury investigation of a price fixing conspiracy

54 In re Auto. Refinishing Paint Antitrust Litig., 2004 U.S. Dist. LEXIS 291612 (E.D. Pa. Sept. 27, 2004).

55 The court granted final approval of a partial settlement with three defendants - Azko, BASF and DuPont - in september 2003. See In re Auto. Refinishing Paint Antitrust Litig., 2004 U.S. Dist. LEXIS 29161. at 3. Plaintiffs obtained final approval of the proposed settlement with PPG and SherwinWilliams, the remaining two defendants, on December 28, 2007. See In re Auto. Refinishing Paint Antitrust Litig., 2007 U.S. Dist. LEXIS 95004 (E.D. Pa. DeC. 28, 2007).

56 In re Auto. Refinishing Paint Antitrust Litig., 358 F.3d 291 (E.D. Pa. Feb. 13, 2004).

57 \$18.75 million was settled by Azko and \$12 million was settled by BASF. See In re Auto. Refinishing Paint Antitrust Litig., 2004 U.S. Dist. LEXIS 291613.

58 In re Auto. Refinishing Paint Antitrust Litig., 2004 U.S. Dist. LEXIS 29161 at 23, 24 . 
among several paint manufacturers. ${ }^{59}$ This article seems to have spurred the private suits that followed. By November 2001, dozens of cases filed in five states by direct purchasers of Automotive Refinishing Paint were consolidated into one class action suit. ${ }^{60}$ Plaintiffs alleged "that defendants combined and conspired with one another to fix, raise, maintain and stabilize the prices that they charged their customers for Automotive Refinishing Paint sold in the United States during the period from January 1, 1993, to December 31, 2000, in violation of Section 1 of the Sherman Act." ${ }^{61}$ The defendants consist of three domestic companies: DuPont, PPG and SherwinWilliams; and two foreign based companies: BASF (Germany) and Akzo Nobel (The Netherlands). ${ }^{62}$ Automotive Refinishing Paint refers to paint products which are applied to motor vehicles directly after the initial manufacturing process; like base coat paint, clear coat paint, primer etc. ${ }^{63}$

Apart from the civil lawsuits, the federal grand jury that was initially investigating the allegations of price fixing was disbanded in 2003.64 The government's closing of the

59 Sheila Loftus, Price Fixing in the Refinishing Industry?, Hammer and Dolly (Mar. 2001).

60 In re Auto. Refinishing Paint Antitrust Litig., 177 F. Supp. 2d 1378, 1379 (J.P.M.L. Nov. 15, 2001).

61 In re Auto. Refinishing Paint Antitrust Litig., 2003 U.S. Dist. LEXIS 181231 (E.D. Pa. Sept. 5 2003).

62 In re Auto. Refinishing Paint Antitrust Litig., 358 F.3d 291 .

63 In re Auto. Refinishing Paint Antitrust Litig., 2003 U.S. Dist. LEXIS 18123 at 29.

64 In re Auto. Refinishing Paint Antitrust Litig., 2004 U.S. Dist. LEXIS 29161 at 24 . 
investigation came after a first settlement was reached with one of the two foreign defendants. ${ }^{65}$ Moreover, the fact that the government chose not to prosecute the case was one factor in the court's approval of the settlement. ${ }^{66}$ The court felt that the settlement was reasonable in light of the best possible recovery and in light of the risks inherent in litigation since the government had already declined to prosecute. ${ }^{67}$

On september 5, 2003, the Court granted final approval to a partial settlement with the Dutch based company Akzo Nobel. ${ }^{68}$ They agreed to pay $\$ 18.75$ million in cash and provided certain discovery. ${ }^{69}$ Subsequently, On September 27, 2004, the court approved a second settlement between plaintiffs and BASF and DuPont. ${ }^{70}$ The German based company BASF agreed to pay $\$ 12$ million in cash and the settlement agreement required DuPont to pay $\$ 36$ million in cash. ${ }^{71}$ In addition, the defendants provided the plaintiffs with information for the discovery consisting of: documents, sales transactional data and the

65 Id.

66 Id. at 23,24

67 Id.

68 In re Auto. Refinishing Paint Antitrust Litig., 2003 U.S. Dist. LEXIS 18123 at 18 .

69 In re Auto. Refinishing Paint Antitrust Litig., 2003 U.S. Dist. LEXIS 46813 (E.D. Pa. Mar. 17, 2003).

70 In re Auto. Refinishing Paint Antitrust Litig., 2004 U.S. Dist. LEXIS 29161 at 29.

71 Id. at 3 . 
permission to interview (former) employees. ${ }^{72}$ The settlement negotiations were tough, but for this settlement "[p] laintiffs have had the benefits of initial, first wave document discovery from all defendants - namely, the grand jury documents defendants produced to the Department of Justice." 73 Moreover, the court granted a fee petition for plaintiff's counsel in the amount of over $\$ 21.5$ million (or 32 percent of the settlements) plus reimbursement of over $\$ 700,000$ in expenses. ${ }^{74}$ The award was made after objections by three of the plaintiffs who argued that a percentage fee was inconsistent with other "mega-fund cases." 75 specifically, they argued that a lodestar method, by which the number of hours counsel spent on the case, should be used to calculate the fee award. ${ }^{76}$ The court overruled the objections and used several of the so-called "Gunter" factors including what they deemed as the high skill and efficiency of plaintiff's counsel, the complexity of the litigation, the lengthy time devoted to the case, and the high risk of non-payment as warranting the percentage fee. ${ }^{77}$ The court in its decision spoke highly of the work done on behalf of the class and even said that

72 In re Auto. Refinishing Paint Antitrust Litig., 2004 U.S. Dist. LEXIS 291632 (E.D. Pa. May 10, 2004).

73 Plaintiffs' Memorandum, at 13.

74 In re Auto. Refinishing Paint Antitrust Litig., 2004 U.S. Dist. LEXIS $29162 * 40$ (E.D. Pa. Oct. 13 2004).

75 Id. at 12 .

76 Id. at 13 .

77 Id. at $11-32$. 
"...Plaintiffs' counsel have repeatedly demonstrated their skill in managing this litigation."78

On December 28, 2007, the court approved plaintiffs' final settlement with the remaining two defendants, PPG and Sherwin-Williams. ${ }^{79}$ This approval came a full six years after the first of the private suits were filed in November 2001 . The agreement required PPG to pay \$23 million and SherwinWilliams agreed to pay \$16 million, bringing the combined total value of all the settlements to $\$ 105.75$ million. The court awarded class counsel's requested one-third fee, plus expenses and incentive awards, for these additional settlements on January 3, 2008. ${ }^{80}$ In that order the court again commended counsel for "the manner in which Petitioners conducted all aspects of this litigation, including the very successful settlement negotiations...." ${ }^{81}$

78 Id. at 20 .

${ }^{79}$ In re Auto. Refinishing Paint Antitrust Litig., 2007 U.S. Dist. LEXIS 95004 (E.D. Pa. Dec. 28, 2007).

${ }^{80}$ In re Auto. Refinishing Paint Antitrust Litig., 2008 U.S. Dist. LEXIS 569 (E.D. Pa. Jan. 3, 2008).

81 Id. at $* 13$ 
In re: Buspirone Antitrust Litigation, 185 F. Supp. 2d 340 (S.D.N.Y. 2002) MDL Doc. No. 1413, and In re Buspirone Patent Litigation, 185 F. Supp.2d 363 (S.D.N.Y. 2002). Final Settlement approval at ( 2003 U.S. Dist. Lexis 25638, April 17, 2003). (BuSpar)

This case is noteworthy because: 1) Although it was not the first case to allege that a patent infringement settlement was actually a horizontal market allocation and therefore a per se violation of the Sherman Act, the \$220 million dollar settlement in this case was the largest recovery in the first wave of such cases; ${ }^{82}$ 2) The settlement exceeds the total amount of overcharges suffered by the Direct Purchaser Class and is approximately 95\% of the total overcharges likely to be incurred through 2006, as estimated by Plaintiff's expert; ${ }^{83} 3$ ) Private counsel was first to investigate and secured a substantial monetary recovery, amounting to more than double the monetary recovery obtained by the federal government; ${ }^{84} 4$ )

82 See: In re Cardizem CD, 105 F. Supp 2d 682 (E.D. Mich. 2000); 332 F.3d 896 ( $6^{\text {th }}$ Cir. 2003) settling for $\$ 175$ million. See also: In re Terazosin Hydrochloride, 352 F.Supp.2d 1279, 1286 (S.D. Fla. 2005) settling for \$75 million.

83 Dr. Jeffrey Leitzinger, Direct Purchaser Class Plaintiff's Motion for Final Approval of Settlement, pg 3, In re Buspirone Antitrust Litigation, MDL No. 1413. (S.D.N.Y. 2003)

84 Attorneys General for Maryland, New York and Texas lead a class of Plaintiff states, securing a $\$ 93$ million settlement to reimburse consumers and state and local agencies for overcharges resulting from Buspar purchases between January 1, 1998 and December 31, 2002. Alabama, et al, V. Bristol-Myers 
The outstanding recovery is a result of Class Counsel's efforts during the discovery process, which produced evidence of the Schein Agreement (discussed below), of which Plaintiffs were not previously aware; 5) Judge John G. Koeltl stated, "let me say that the lawyers in this case have done a stupendous job. They really have, ${ }^{\prime 85}$ when he approved the settlement and awarded Class Counsel one third of the recovery in attorney's fees; 6) This case was the first of several involving BMS's strategies for delaying generic competition with its brand-name drugs (all told, BMS paid out \$670 million dollars in settlements of antitrust suits arising from BuSpar, Taxol and Platinol) $;^{86}$ and 7 ) The size of the settlement will

Squibb Co, et al, No. 01-CV. 11401, MDL 1413 (available at http://www.naag.org). The Federal Trade Commission (FTC) cooperated with the state attorneys general to obtain injunctive relief through a consent order which was finalized on April 14, 2003 and terminates on April 14, 2013. In the Matter of Bristol-Myers Squibb Co., Docket No. C-4076, Decision and Order (available at Federal Trade Commission, Bureau of Competition: Case Filings, http://ftc.gov/os/2003/04/bristolmyerssquibbdo.pdf (last updated December 14, 2001)). The order prohibits BMS from engaging in specific anticompetitive tactics including those used by the company to obstruct the entry of generic versions of Buspar and Taxol, and requires BMS to abide by certain reporting procedures for five years.

85 See www.milbergweiss.com/whymilberg? Citing: In re Buspirone Patent Litigation, MDL Docket No. 1413 at 34:2-3 (S.D.N.Y. Nov. 6, 2003) (Final Approval Hearing Transcript).

86 John R Wilke, Bristol-Myers Settles Charges of Patent-Law Abuse, The Wall Street Journal, Sec. A pg 5, Col. 1, Mar. 10, 2003. "Bristol-Myers Squibb Co. settle FTC complaint that it 
discourage other brand-name drug manufacturers from using the same tactics to delay or prevent generic competition, helping to keep national healthcare costs down by keeping prescription drugs competitively priced. ${ }^{87}$

In 1980 Bristol-Myers Squibb Company ("BMS") obtained a patent ("the '763 Patent") for treating anxiety with buspirone, an anti-anxiety drug. The patent was set to expire on November 21, 2000. Since 1986, when buspirone was approved by the FDA, BMS has been selling it under the brand name Buspar. Just before this patent was about to expire, BMS obtained another patent ("the '365 Patent") for one of the metabolites ${ }^{88}$ that buspirone naturally produces in the body. BMS told the FDA that any manufacture of a generic version of buspirone would violate this second patent. ${ }^{89}$

illegally sought to extend patent protection on its drugs BuSpar, Taxol and Platinol; company agreed in January [2003] to pay $\$ 670$ million to resolve related lawsuits by states, generic-drug makers and pharmacies."

87 See: Elyse Tanouye, Prices of Drugs Increase Faster than Inflation, The Wall Street Journal, pg B4, Feb. 13, 1997.

88 The metabolite covered by the patent -6-hydroxy-buspironeis a separate chemical compound that the body naturally produces after taking buspirone. See: Adams, Delayed Reaction; Drug Manufacturers Step Up Legal Attacks That Slow Generics That's One Reason It Takes Longer to Approve Knock-Off's than Brands --The 'Metabolite Defense,' The Wall street Journal, pg A1, Jul. 12, 2001.

89 "On Dec. 4, [2001], an attorney for Bristol-Myers faxed a letter to the FDA, saying the [1365] patent did cover 
In anticipation of the expiration of BMS's '763 Patent, several generic drug manufacturers ${ }^{90}$ filed Abbreviated New Drug Applications" ("ANDAs") with the FDA, seeking approval to begin selling generic versions of buspirone. "Approximately eleven hours before the 1763 Patent expired, Bristol-Myers hand-delivered copies of the 1365 Patent to the FDA and applied to have it listed in the Orange Book as covering buspirone." 92 Because of this listing in the Orange Book, ${ }^{93}$ BMS' subsequent filing of patent infringement suits against the generic manufacturers triggered an automatic stay of FDA

swallowing Buspar -even though the company had told the patent office that it covered only swallowing the metabolite." Gardiner Harris and Chris Adams, Delayed Reaction; Drug Manufacturers step Up Legal Attacks That Slow Generics -That's One Reason It Takes Longer to Approve Knock-Off's than Brands --The 'Metabolite Defense,' The Wall Street Journal, pg A1, Jul. 12, 2001 .

90 Specifically, the generic manufacturers were: Danbury Pharmacal, Inc., Watson Pharmaceuticals, Inc., Mylan Pharmaceuticals, Inc., Mylan Laboratories, Inc., and Mylan Technologies, Inc..

91 For a detailed explanation of the Hatch-Waxman Act and Orange Book procedures involved this litigation see: In re: Buspirone Antitrust Litigation, 185 F. Supp. 2d 340, 345-346 (S.D.N.Y. 2002)

92 In re: Buspirone Antitrust Litigation, 185 F. Supp. 2d 340, 350 (S.D.N.Y. 2002) citing Mylan Pharm., Inc. V. Thompson, 139 F. Supp. 2 d at 8 .

93 The "Orange Book: is an official FDA publication formally know as "Approved Drug Products with Therapeutic Equivalence Evaluations." 
approval of their applications for 30 months or until the patent infringement actions reached final resolution. ${ }^{94}$ Mylan Laboratories, Inc. ${ }^{95}$ ("Mylan") had already loaded trucks with generic buspirone and was ready to ship the product at 12:00 am on November 22, 2000 when approval of its ANDA was delayed by the patent infringement suit filed by BMS. ${ }^{96}$

The second method BMS used to protect sales of its drug against competitors was to pay Schein Pharmaceutical, Inc. ${ }^{97}$ ("Schein") \$72.5 million over four years not to enter the buspirone market ("the Schein Agreement"). Schein and BMS

94 The generic manufacturers whose ANDA's were suspended, immediately filed for injunctive relief in Federal Court. See: Mylan Pharm., Inc. V Thompson, 139 F. Supp. 2d at 8-9 and Watson Pharm., Inc. V. Henney, 194 F. Supp. 2 d 442 (Dist. MD. 2001). The patent infringement litigation proceeded and in February 2002 the generics won a motion for summary judgment declaring the second patent did not cover buspirone. In re: Buspirone Patent Litigation, 185 F. Supp. 2d 340. (S.D.N.Y. 2002).

95 Mylan Laboratories is based in West Virginia.

96 Gardiner Harris and Chris Adams, Delayed Reaction; Drug Manufacturers step Up Legal Attacks That Slow Generics -That's One Reason It Takes Longer to Approve Knock-Off's than Brands --The 'Metabolite Defense,' The Wall Street Journal, pg A1, Jul. 12, 2001. See also: In re: Buspirone Antitrust Litigation, 185 F. Supp. 340, 346 (S.D.N.Y. 2002).

97 Schein Pharmaceutical Inc. ("Schein") is now a subsidiary of Watson Pharmaceuticals, Inc. ("Watson"), which is one of the generic companies seeking FDA approval for a generic version of buspirone. Watson settled its antitrust claims with BMS for \$32 million in 2002. See: BMS Settles Antitrust Charges Involving Buspar, Generic Line, Vol. 19, No. 7, April 5, 2002. 
characterized the 1994 agreement as a settlement of a patent infringement suit regarding the original patent. However, plaintiffs alleged that the settlement "was a sham used to cover up an unlawful anticompetitive arrangement under which Schein agreed to stay out of the buspirone market and help maintain a public perception that the 1763 Patent was valid ... even though both parties knew that the 1763 patent was not valid." 98

Mylan launched its generic busprione product in April, 2001, five months later than scheduled. The delay "yielded some $\$ 200$ million in additional exclusive sales of Buspar."99 By the end of June 2001, generics had captured two- thirds of Buspar's market share. ${ }^{100}$

On August 12, 2001 four patent disputes ${ }^{101}$ and twenty- two antitrust actions ${ }^{102}$ were consolidated for pre-trial purposes in the Southern District of New York. The Direct Purchaser

98 In re: Buspirone Antitrust Litigation, 185 F. Supp. at 366.

99 Gardiner Harris and Chris Adams, Delayed Reaction; Drug Manufacturers step Up Legal Attacks That Slow Generics -That's One Reason It Takes Longer to Approve Knock-Off's than Brands --The 'Metabolite Defense,' The Wall Street Journal, pg A1, Jul. 12, 2001 .

100 Id.

101 These suits had been consolidated under MDL-1410.

102 These twenty two suits had been consolidated under MDL1413 . 
Class $^{103}$ alleged that the Schein Agreement, the listing of the '365 patent in the Orange book and the sham patent infringement suits filed against competitors were anticompetitive acts designed to preserve BMS's monopoly over the buspirone market.

After two years of intense litigation, the parties agreed to settle for a cash payment of $\$ 220$ million. Class Counsel was in a position to negotiate such a substantial settlement because in the course of the litigation they discovered the Schein Agreement and amended their complaint, and because their motion for partial summary judgment arguing that the Schein Agreement was per se illegal under the Sherman Act had been fully briefed but not yet decided. During the two years leading up to the settlement, which was preliminarily approved by the court on January 31, 2003, Class Counsel spent more

103 The Direct Purchaser Class is defined as "All persons who have directly purchased BuSpar(R) from defendant Bristol-Myers Squibb Company any time during the period November 9, 1997 through January 28, 2003 ("Direct Purchaser Class" or the "Class"). Excluded from the Class are the defendants in this lawsuit, and their officers, directors, management and employees, subsidiaries and affiliates, and federal government entities. Also excluded from the Class are the claims brought by and/or assigned to entities which independently sued BMS in the actions styled CVS Meridian, Inc. and Rite Aid Corp. V. Bristol-Myers Squibb Co., et. al., No. 01-CV-10223, and Walgreen Co., et. al. V. Bristol-Myers Squibb Co., et. al., No. 02-CV-2952, as well as claims asserted by certain states in the action styled State of Alabama et. al. V. Bristol-Myers Squibb Co., et. al., No. 01 CV 11401." In re: Buspirone Antitrust Litigation, MDL Doc. No. 1413 at pg 6 (2003 U.S. Dist. Lexis 26538). 
than 28,000 hours and conducted exhaustive discovery, prepared numerous expert witnesses and engaged in extensive motion practice, including a successful motion for class certification. In a decision filed April 17, 2003, the Honorable John G. Koeltl for the district court awarded Class Counsel one third of the total recovery from which the $\$ 811,338.41$ in expenses were to be deducted. ${ }^{104}$

As this settlement was in the final stages of negotiation, on March 7, 2003 the FTC issued its first complaint against BMS. The complaint accused Bristol-Meyers Squibb of a decade-long pattern of alleged anticompetitive acts: "Bristol avoided competition by abusing federal regulations in order to block generic entry; deceived the U.S. Patent and Trademark Office (PTO) to obtain unwarranted patent protection; paid a would-be generic rival over $\$ 70$ million not to bring any competing products to market; and filed baseless patent infringement lawsuits to deter entry by generics."105

104 In re Buspirone Antitrust Litigation, Order and Final Judgment, pg 5, In 14, MDL Docket No. 1413, April 7, 2003. The court also awarded named plaintiff Louisiana Wholesale Drug. Co., Inc $\$ 25,000$ as an incentive award. Id. at pg 6, In 16 .

105 Press Release: FTC Charges Bristol-Myers Squibb with Pattern of Abusing Government Processes to Stifle Generic Drug Competition, March 7, 2003, quoting Joe Simons, Director of the FTC's Bureau of Competition (available at www.ftc.gov). 
The complaint resulted in a consent order ${ }^{106}$ which will prevent BMS from using similar tactics in the future. Attorneys

General for Maryland, New York and Texas, who lead a class of Plaintiff States, worked with the FTC in securing this agreement and also settled their claims against BMS for $\$ 93$ million dollars in $2003 .{ }^{107}$

The FTC action and the substantial amount that BMS paid to various plaintiffs in settlement of buspirone claims should discourage other brand- name drug manufacturers from using such agreements to delay or prevent generic competition, helping to keep national healthcare costs down by keeping prescription drugs competitively priced. ${ }^{108}$

106 Decision and Order, Docket No. C-4076, April 18, 2003 (available at www.ftc.gov).

107 The Plaintiff states initiated formal action against BMS in December, 2001. A summary of the efforts of Attorneys General in this case go to: www.naag.org. According to Meredyth Smith Andrus, Deputy Attorney General for the Antitrust Division of the Maryland Attorney General's Office, the Attorneys General and the FTC led parallel investigations of BMS and separately negotiated their settlements. Attorneys General will often conduct a non-public investigation, long before a complaint is filed. In this case, the attorneys general first took formal action in 2001 but they may have been looking into the agreement long before that so it is difficult to say with absolute certainty that private counsel initiated the investigation.

108 See: Prepared Statement of the Federal Trade Commission Before the Committee on the Judiciary, United States Senate, "Competition in the Pharmaceutical Marketplace: Antitrust Implications of Patent settlements," May 24, 2001, (available at: www.ftc.gov); and Elyse Tanouye, Prices of Drugs Increase 
Caldera, Inc. V. Microsoft Corp., Case No. 2:96CV645B, 72 F.Supp.2d 1295 (D. Utah 1999).

This case is notable because: 1) Although the amount of the settlement is confidential, the Wall street Journal estimated that Microsoft paid approximately $\$ 275$ million to settle with Caldera; ${ }^{109} 2$ ) This case was filed by a competitor and was not, in its essence, a follow-up to any case brought by the U.S. government, a State, or the European Union against Microsoft; and 3) This case disclosed important information regarding Microsoft's anticompetitive conduct to consumers.

In July 1996, Caldera filed suit against Microsoft, its competitor in the computer operating system market, for illegal tying and monopolization in violation of sections 1

Faster Than Inflation, The Wall Street Journal, pg B4, Feb. $13,1997$.

${ }^{109}$ See Lee Gomes, Microsoft To Settle Suit By Caldera, The Wall Street Journal A3 (Jan. 11, 2000). This estimate was based on Microsoft's reported charge to pay the settlement and its tax rate. "Microsoft Corp. agreed to pay an estimated $\$ 275$ million to settle an antitrust lawsuit by Caldera Inc., heading off a trial that was likely to air nasty allegations from a decade ago. Microsoft and Caldera, a small salt Lake City software company that brought the suit in 1996, didn't disclose terms of the settlement. Microsoft, though, said it would take a charge of three cents a share for the agreement in the fiscal third quarter ending March 31. Since the company has roughly 5.5 billion shares outstanding, the cost of the deal would appear to be about \$165 million. Michael Kwatinetz, an analyst at Credit Suisse First Boston, estimated Microsoft paid about \$275 million, based on its tax rate." 
and 2 of the Sherman Act. Caldera and Microsoft both produced versions of the computer operating system, Dos. Caldera alleged that its DR-DOS offered more features that consumers wanted. 110 However, according to Caldera, Microsoft tied its MS-DOS operating system and its Windows graphical interface, allowing Microsoft to maintain an illegal monopoly in the computer operating system market with MS-DOS.

Microsoft had already entered into a Consent Decree with the United States Department of Justice and a similar agreement with the European Union regarding certain licensing violations when Caldera filed suit. ${ }^{111}$ Caldera alleged that Microsoft continued to engage in anticompetitive conduct involving its operating systems, including violations for: (1) unreasonably long licensing agreements with original equipment manufacturers (OEMs); (2) pricing schemes that forced OEMs to only buy MS-DOS; (3) tying MS DOS with Windows; (4) giving deep discounts to OEMs that were vulnerable to competition;

110 For example, DR-DOS operated at a faster speed and was less expensive than MS-DOS. See Caldera, Inc. V. Microsoft Corp., 72 F.Supp.2d 1295, 1298.

111 The U.S. and European government cases alleged licensing violations, including some involving operating systems. The subsequent Consent Decree barred, among other things, conditioning licensing agreements of Microsoft operating system products on the license of another Microsoft product. See Final Judgment, United States v. Microsoft Corp., No. 941564 (July 15, 1994). 
(5) false public statements regarding Windows' compatibility with DR-DOS; (6) unlawful "beta blacklisting" in order to stop pre-testing the compatibility of Windows and DR-DOS; (7) false public statements made about the timing of the release of MSDos to coincide with the release of new versions of DR-DOS;

(8) intentionally programming code into Windows with the sole purpose of displaying false error messages when running on DRDos; and (9) "peer processor royalties," also referred to as "the Microsoft tax."

In early 1998, Caldera filed an amended complaint, expanding its claims to include allegations that Microsoft tied MS-DOS to Windows 95 in an attempt to eliminate DOS competition. ${ }^{112}$ This claim was especially unique and has since appeared in the government cases that have followed. ${ }^{113}$

Microsoft subsequently filed nine separate motions for summary judgment seeking to dismiss this and many of Caldera's other claims. In response Caldera filed a statement of Facts,

112 Andrew Schulman, The Caldera V. Microsoft Dossier, 2/7/2000, available at: www. oreillynet.com/pub/a/network/2000/02/07/schulman.html.

113 See United States v. Microsoft Corp., No. Civ. A. 98-1232, 1998 U.S. Dist. LEXIS 14231, 1998 WL 614485 (D.D.C. Sept. 14 1998). Microsoft had previously asserted that Windows 95, unlike previous versions of Windows, was an integrated operating system rather than an illegal combination of Windows and MS-DOS. See Consolidated Statement of Facts in support of Its Responses to Motions for summary Judgment by Microsoft Corporation, generally, Caldera, Inc. V. Microsoft Corp., 72 F.Supp.2d 1295 . 
making public much of its evidence against Microsoft, including emails sent by Bill Gates directing his development staff to identify ways that an application would run only with MS-DOS and not with DR-DOS. ${ }^{114}$ Judge Dee Benson denied Microsoft's motions for summary judgment, ruling that Caldera's evidence was sufficient to support its claims and present them to a jury. ${ }^{115}$

The parties entered into a settlement agreement on January 9, 2000, less than one month before the case was scheduled to go to a jury trial. The timing of the settlement was also significant given the additional cases brought by the United States and European Union which had yet to be resolved, and Microsoft had recently prevailed in a jury trial action brought by Bristol, another of its competitors. ${ }^{116}$ Some commentators concluded that the settlement represented the

114 See Consolidated Statement of Facts in Support of Its Responses to Motions for Summary Judgment by Microsoft Corporation, at paragraph 38, Ex. 16.

115 Memorandum Opinion and Order (June 28, 1999). Judge Benson's rulings were upheld on appeal. See Caldera, Inc. v. Microsoft Corp., 87 F.Supp.2d 1244 (D. Utah 1998) (Plaintiff's allegations were sufficient to support its claims of predatory practices and illegal restraint of trade in violation of sections 1 and 2 of the Sherman Act); and Caldera V. Microsoft Corp., 72 F.Supp.2d 1295 (D. Utah 1999) (Denying Defendant's motions for partial summary judgment on Plaintiff's claims of predisclosure, perceived incompatibilities, intentional incompatibilities, and technological tying).

116 See Bristol Technology Inc. v. Microsoft Corporation, Case No. 398-CV-1567 (D. Conn. Dec. 30, 1998). 
first acknowledgment by Microsoft that "Caldera had a solid case," and had not been simply playing the "litigation lottery." ${ }^{117}$

Consumers received important information regarding Microsoft's conduct as a result of the discovery in this case. A consulting expert on the case noted, "Confidential settlements typically allow evidence of corporate wrongdoing to remain hidden. However, the settlement of Caldera $\mathrm{v}$. Microsoft isn't quite like this."118 Caldera released a series of "smoking gun" emails, which included one email from Bill Gates that threatened "the price of Windows without MS DOS would be twice as much" to companies that sold personal computers to consumers. ${ }^{119}$

117 It had been Microsoft's contention that in purchasing DRDOS from Novell for $\$ 400,000$, Caldera bought the lawsuit in the hopes of winning a big payout from the industry giant. The Caldera v. Microsoft Dossier.

118 Id.

119 First Amended Complaint and Jury Demand, at paragraph 55, Caldera, Inc. v. Microsoft Corp., 72 F.Supp.2d 1295. 
In re: Cardizem CD Antitrust Litigation, MDL Docket No. 1278; 105 F.Supp 2d 682 (E.D. MiCh. 2000); 332 F.3d 896 (6 th $^{\text {Cir. }}$ 2003 ).

This case is noteworthy because: 1) It was the first of several cases that challenged the validity of settlement agreements between brand-name pharmaceuticals and their generic competitors: as the Judge noted, "[t]his case has helped put prescription drug pricing and marketing tactics at the forefront of media, Congressional scrutiny, and judicial scrutiny;"120 2) The initial investigation apparently was led by private counsel and followed by an FTC investigation; ${ }^{121} 3$ )

120 Order granting Sherman Act Class Plaintiffs' Motions for Final Approval of Settlement, Plan of Allocation and Sherman Act Class Counsel's Joint Petition for Attorney's Fees, Reimbursement of Expenses, and Incentive Awards for Named Plaintiffs. Order No. 49 at 22. In re Cardizem CD, MDL no. 1278 (E.D. Mich 2004).

121 Private counsel began an investigation in June 1998. In re Cardizem CD Antitrust Litigation, 218 F.R.D. 508, 511 (E.D. Mich. 2003). "These cases began after an intensive private investigation, conducted by Co-Lead Counsel for the state Law Plaintiffs in June 1998, two months before the first class action case was filed. Lowey Dannenberg Bemporad \& Selinger ("LDBS") was informed of the existence of the september 1997 HMRI/Andrx Agreement by a confidential source in June 1998 . Thereafter, LDBS engaged in an intensive pre-litigation investigation of factual and legal issues relevant to this litigation. (Pls.'s Motion, 9/22/03 Lowey Decl. (describing in detail pre-litigation investigation).) In August 1998, Norman Morris, a California pharmacist, and Betty Morris, his wife who was a consumer of Cardizem CD, retained LDBS and Co-Lead Counsel Berman DeValerio Pease Tabacco Burt \& Pucillo ("BDPT") to commence the first lawsuit related to the september 1997 HMRI/Andrx Agreement. LDBS and BDPT filed a comprehensive California state law complaint on the Morris's behalf In 
California state court on August 20, 1998 as a putative class action (the "Betnor action"). The following day, The Wall Street Journal published a story concerning the Betnor complaint. This publicity led to inquiries to Co-Lead Counsel from in-house counsel at Aetna and Cobalt (formerly known as "United Wisconsin Services"), the parent company of Wisconsin Blue Cross, about the possibility of their serving as class representative plaintiffs. Within several months, actions were filed in 11 different states and the District of Columbia. All were filed in state courts, under state antitrust and related laws, by consumers and health insurers. In late 1998 and early 1999, various wholesalers, or retailers who had obtained assignments of claims from wholesalers, filed direct purchaser class actions under the Sherman Antitrust Act, reiterating the allegations of the Betnor complaint, but asserting federal antitrust claims not available to the state Law Plaintiffs who were indirect purchasers of Cardizem CD." Id. at 511-512 (internal citations omitted).

Although the FTC did not file a complaint until March 16, 2000, it was looking into the agreement as early as March 9, 1999. See: Ralph T. King Jr., "Drugs: FTC widens Prove Into Generic-Drug Barriers," The Wall Street Journal. Mar. 9, 1999. Pg B-1. (The first private complaints in this case were filed in November 1998 and February 1999.) see also: Jerry Guidera and Ralph T. King Jr., "Abbot Labs, Novartis Unit Near Pact With FTC Over Agreement on Hytrin," The Wall street Journal. Mar. 14, 2000, pg B6, writing that the FTC probe "of the drug industry's alleged efforts to block generic rivals and thus protect sales of brand-name medications" was "launched about a year ago." Id.

Working with the FTC, class of states led by Attorneys General for Michigan and New York initiated proceedings against HMS/Aventis in 2001 which settled for $\$ 80$ million dollars in 2003. The FTC secured a consent order preventing HMR from entering into such agreements in the future. See infra, fn 14 .

In some cases the Attorneys General, the DOJ, and/or the FTC will conduct a lengthy non-public investigation before filing a complaint, making it difficult to determine whether the government or private counsel began investigating first, or were conducting separate, parallel investigations. In this case, the attorneys general first took formal action in 2001 but they may have been looking into the agreement long before that so it is difficult to say with absolute certainty that 
Counsel for the Direct Purchaser Class persuaded the court that the agreement was a per se violation of the Sherman Act, the first time such an agreement was declared per se illegal; 2) Counsel for the Direct Purchaser Class secured a cash settlement of $\$ 110$ million, ${ }^{122}$ which, according to plaintiffs' expert economist, represents more than $200 \%$ of the total amount the Class was overcharged ${ }^{123}$ during the period the illegal agreement was in effect; ${ }^{124}$ and 3 ) in her opinion approving the final settlement, Judge Nancy G. Edmunds for the Eastern District of Michigan awarded Class Counsel their requested thirty percent of the total recovery in attorneys' fees, noting that the award was justified by their "excellent

private counsel initiated the investigation. However, the fact that private counsel first filed a complaint as early as 1998 supports the inference that this case was initiated by private counsel.

122 Andrx recorded a \$60 million litigation settlements charge in the second quarter of 2002 for all pending litigation relating to Cardizem CD. Andrx 2002 Annual Report (available at http://www.andrx.com). However, although HMR and Andrx collectively paid into the settlement fund, the proportion contributed by each is confidential as per the settlement agreement. Settlement Agreement, In re Cardizem CD, MDL No. 1278 (E.D. Mich. 2004).

123 Memorandum in Support of Sherman Act Class Plaintiff's Motion for Final Approval of Settlement, filed 11/04/2002, In re Cardizem CD Antitrust Litigation, MDL Docket No. 1278, at page 2 (E.D. Mich. 2002).

124 September 24, 1997 through June 9, 1999. 
performance on behalf of the Class in this hotly contested case. ${ }^{125}$

The litigation stems from a 1997 agreement whereby HMR, manufacturer of the brand-name drug Cardizem CD, agreed to pay \$40 million a year to Andrx, a generic drug manufacturer, in return for Andrx's promise not to produce or sell its generic version of Cardizem CD. Plaintiffs alleged that this agreement delayed generic competition and kept prices for Cardizem CD artificially high in violation of the Sherman Act. Cardizem $C D$ is the brand-name version of diltiazem hydrochloride, which is used for the treatment of angina and hypertension and for the prevention of heart attacks and strokes. While Andrx's generic version was still in development, the company anticipated the possibility of a patent infringement suit being filed by HMR and, in the hopes of avoiding litigation, Andrx provided samples of its version of the drug to HMR so that HMR scientists could perform their own tests and be sure that the Andrx version did not infringe on the HMR patent. In September 1995, Andrx filed an

125 Order granting Sherman Act Class Plaintiffs' Motions for Final Approval of Settlement, Plan of Allocation and Sherman Act Class Counsel's Joint Petition for Attorney's Fees, Reimbursement of Expenses, and Incentive Awards for Named Plaintiffs. Order No. 49 at pg 21. In re Cardizem CD, MDL No. 1278 (E.D. Mich. 2004). 
abbreviated new drug application ("ANDA") with the FDA

requesting approval to begin marketing a generic version of

diltiazem hydrochloride. As required by the Hatch-Waxman

Act, ${ }^{126}$ Andrx filed a certification that its generic product

did not infringe on any of the patents listed with the FDA.

126 The complicated provisions of the Hatch-Waxman act provide the backdrop for this and similar litigation. Under its provisions, the first generic manufacturer to file an ANDA is entitled to a 180-day exclusivity period. Each ANDA must be accompanied by a certification that the drug for which they seek approval does not infringe on a legitimate patent right because the patent is either invalid, expired, or will not be infringed by the marketing of the generic drug. The patent holder is entitled to notice of this certification and, can immediately file a patent infringement suit against the generic competitor. Filing a patent infringement suit triggers an automatic stay of FDA approval of the generic manufacturer's ANDA for 30 months or until the patent litigation is resolved. 21 U.S.C. 355. Relevant provisions of the Hatch-Waxman Act were amended in 2003 See: The Medicare Prescription Drug, Improvement, and Modernization Act of 2003, Title XI: Access to Affordable Pharmaceuticals, sections a-b, United States Public Laws, $108^{\text {th }}$ Congress $-1^{\text {st }}$ Session, 108 P.L. 173 (2006). The amendments adopt FTC recommendations that brand-name companies be limited to one 30-month stay of approval, that a counterclaim for improper Orange Book listing be authorized for generic companies faced with patent infringement suits, and that limits be put on the 180 day exclusivity period. Statement of the Honorable Timothy J. Muris before the Senate Judiciary committee. Aug. 1, 2003. For a history of the act and a discussion of the recent amendments See: Elizabeth Stotland Weiswasser \& Scott D. Danzis, The Hatch-Waxman Act: History, structure and Legacy, 71 Antitrust L.J. 585 (2003). For a discussion of the 2003 amendments and the loop holes that still exist see: Brian Porter, Comment: Stopping the Practice of Authorized Generics: Mylan's Effort to Close the Gaping Black Hole in the Hatch Waxman Act, $22 \mathrm{~J}$. Contemp. Health L. \& Pol'y 177 (Fall 2005). For an overview of the Act and how it has been manipulated by brand-name pharmaceutical manufacturers as well as differing views as to how such manipulations should be treated see: Eric L. Cramer 
In November 1995, HMR obtained patent ${ }^{127}$ rights for a new version of diltiazem hydrochloride with a different dissolution profile. The following January, HMR and Carderm Capital L.P. ("Carderm") ${ }^{128}$ filed a patent infringement suit against Andrx claiming that the generic drug it intended to market would violate their new patent. The filing of this suit triggered an automatic stay of FDA approval of Andrx's ANDA for 30 months or until the patent infringement litigation reached a final resolution. Andrx countered with unfair competition and antitrust claims against HMR and Carderm.

The parties settled the patent infringement suit in 1997: HMR agreed to pay Andrx $\$ 40$ million a year, as long as Andrx did not bring its generic drug to the market. By the time this arrangement was terminated by agreement of both parties in June 1999, HMR had paid Andrx a total of $\$ 89.83$ million. After its subsequent release on June 23, 1999,

and Daniel Berger, The Superiority of Direct Proof of Monopoly Power and Anticompetitive Effects in Antitrust Cases Involving Delayed Entry of Generic Drugs, 39 U.S.F. L.Rev. 81 (Fall 2004), Herbert Hovenkamp et al., Anticompetitive Settlement of Intellectual Property Disputes, 87 Minn. L. Rev. 1719 (20030), and Kristopher L. Reed, A Return to Reason: Antitrust Treatment of Pharmaceutical settlements Under the Hatch-Waxman Act, 40 Gonz. L. Rev. 457 (2004/2005).

127 U.S. Patent No. 5,470,584 was issued to Carderm Capital, L.P. and licensed to HMR.

128 See material two notes earlier. 
Andrx's generic diltiazem hydrochloride drug, Cartia XT sold for a much lower price that Cardizem CD and captured a substantial portion of the market. ${ }^{129}$

The firm of Lowey Dannenberg Bemporad and Selinger ("LDBS") began investigating the HMR/Andrx agreement in June 1998 after receiving an anonymous tip. ${ }^{130}$ After LBDS conducted an investigation, complaints were filed on behalf of several classes of plaintiffs beginning in August 1998. Thanks to the publicity of an article in the Wall street Journal ${ }^{131}$ the issue received national attention.

In 1999, the FTC launched a "probe of the drug industry's alleged efforts to block generic rivals and thus protect sales of brand-name medications." ${ }^{132}$ The FTC filed a complaint against HMR and Andrx on March 16, $2000^{133}$ which was resolved

129 In re Cardizem CD Antitrust Litigation, 332 F.3d 896, 903 $\left(6^{\text {th }}\right.$ Cir. 2003).

130 In re Cardizem CD Antitrust Litigation, 218 F.R.D. 508, 511 (E.D. Mich. 2003).

131 Ralph T. King, Drugs: Novel Heart-Drug Deal Protects Sales, Spurs Suit, The Wall Street Journal, Aug. 21, 1998, Pg B1.

132 Jerry Guidera and Ralph T. King Jr., Abbot Labs, Novartis Unit Near Pact With FTC Over Agreement on Hytrin, The Wall Street Journal. Mar. 14, 2000, pg B6.

133 In the Matter of Hoechst Marion Roussel, Inc.; Carderm Capital L.P.; and Andrx Corporation, Complaint, March 16, 2000, Docket No. 9293, available at: www.ftc.gov. 
with a consent order whereby HMR and Andrx agreed not to enter into similar agreements in the future. ${ }^{134}$

Class Counsel filed class action suits on behalf of Direct Purchasers on November 18, 1998 and February 22, 1999. ${ }^{135}$ The claims were consolidated and Plaintiff' motion for certification of a class of direct purchasers was granted on March 14, 2001. ${ }^{136}$ In addition to the substantial $\$ 110$ million settlement, Class Counsel's greatest success was winning a motion for partial summary judgment in which the court held that the agreement whereby HMR paid Andrx not to enter the market was a "naked, horizontal restraint of trade

134 See: "Analysis to Aid Public Comment on Both Consent Orders," April 2, 2001. Docket No. 9293, available at www. ftc.gov.

135 The first complaint filed by purchasers arising from these facts was based on California state Law and was filed on August 20, 1998. Only the direct purchaser actions are under Federal Antitrust laws. There were eventually five groups of plaintiffs: 1) consumers and third party payers, the state Law Plaintiffs 2) Litigating states represented by their attorney generals; 3) direct purchasers 4) individual retailers and chains that opted out of the Direct Purchaser Class and 5) individual blue cross plaintiffs. The Litigating states coordinated their prosecution and settlement with the state Law Class. Together, they settled for \$80 million dollars.

136 The final Direct Purchaser Class consisted of all persons (or assignees of such persons) who directly purchased Cardizem CD from HMR (now Aventis) between september, 1998 and June 23, 1999 . 
and, as such, per se illegal."137 Defendants appealed the class certification and the grant of partial summary judgment to the Sixth Circuit and lost. ${ }^{138}$ After nearly four years of litigation the case finally settled for a cash payment of \$110 million. ${ }^{139}$

Class Counsel expended more than 37,000 hours litigating this case over the course of four years, preparing successful motions for class certification and partial summary judgment, and coordinating an "efficient discovery effort that included the filing of numerous motions to compel, the review of over a million pages of documents and conducting over 25 depositions of witnesses."140 In approving the final settlement, the court

137 In re Cardizem CD Antitrust Litigation, 332 F.3d at 905. Citing the district court opinion, In re Cardizem CD Antitrust Litigation, 105 F. Supp. 2d 682, 705-06 (E.D. Mich. 2000).

138 Id.

139 See: Order granting Sherman Act Class Plaintiffs' Motions for Final Approval of Settlement, Plan of Allocation and Sherman Act Class Counsel's Joint Petition for Attorney's Fees, Reimbursement of Expenses, and Incentive Awards for Named Plaintiffs. Order No. 49 at 3. In re Cardizem CD, Master File No. 99-md-1278, MDL no. 1278. (E.D. Mich 2004). The Litigating states and State Law Class coordinated their settlement efforts and settled for a combined \$80 million dollars. See: In re Cardizem CD Antitrust Litigation, 218 F.R.D. 508, MDL No. 1278 (E.D. Mich. 2003).

140 Order granting Sherman Act Class Plaintiffs' Motions for Final Approval of Settlement, Plan of Allocation and Sherman Act Class Counsel's Joint Petition for Attorney's Fees, Reimbursement of Expenses, and Incentive Awards for Named 
observed that "[t] he complexity of this case cannot be overstated. Despite its complexity, Class Counsel was able to efficiently and effectively prosecute and settle this matter."141 The court granted Class Counsel's request for reimbursement of $\$ 1,080,231.74$ in expenses and thirty percent of the total recovery in the case, noting that, "this court would be remiss if it failed to acknowledge the experience, hard work, and skill demonstrated by Class Counsel in this matter. Their excellent performance on behalf of the Class in this hotly contested case justifies the award they seek."142 Like other antitrust litigation involving brand-name pharmaceutical companies such as In re: Terazosin Hydrochloride, ${ }^{143}$ the success of private counsel in securing a substantial settlement and persuading the court that such agreements are a per se violation of the Sherman Act will discourage other brand-name drug manufacturers from using such agreements to delay or prevent generic competition, helping to

Plaintiffs. Order No. 49 at 3. In re Cardizem CD, Master File No. 99-md-1278, MDL no. 1278 (E.D. Mich 2004).

141 Id. at $20-21$.

142 Id. at 21 .

143 In re Terazosin Hydrochloride, 352 F.Supp. 2d 1279 (S.D. Fla 2005). In re Terazosin Hydrochloride involved a similar agreement between a brand-name manufacturer and its generic competitor. Plaintiffs in that case won a motion for summary judgment on the same issue and secured a cash settlement. 
keep national healthcare costs down by keeping prescription drugs competitively priced. ${ }^{144}$ The particular importance of this litigation was recognized by the court. "This case has helped put prescription drug pricing and marketing tactics at the forefront of media, Congressional scrutiny, and judicial scrutiny. Encouraging qualified counsel to bring inherently difficult and risky by beneficial class actions like this case benefits society."145

144 See: Prepared Statement of the Federal Trade Commission Before the Committee on the Judiciary, United States Senate, "Competition in the Pharmaceutical Marketplace: Antitrust Implications of Patent Settlements," May 24, 2001, (available at: www.ftc.gov); and Elyse Tanouye, Prices of Drugs Increase Faster Than Inflation, The Wall Street Journal, pg B4, Feb. 13, 1997.

145 Order granting Sherman Act Class Plaintiffs' Motions for Final Approval of Settlement, Plan of Allocation and Sherman Act Class Counsel's Joint Petition for Attorney's Fees, Reimbursement of Expenses, and Incentive Awards for Named Plaintiffs. Order No. 49 at 22. In re: Cardizem CD, MDL no. 1278. (E.D. Mich 2004). 
In re: Citric Acid Antitrust Litigation, MDL Docket No. 1092 ; 996 F. Supp. 951 (N. Dist. Cal. 1998).

Summary: The citric acid litigation is noteworthy because: 1) The FBI uncovered the price-fixing conspiracy while investigating the price-fixing conspiracy for lysine; 2) The class-action suit settled for $\$ 86.2$ million, of which $\$ 51.2$ million came from two foreign defendants; 3) Four of the largest purchasers of citric acid opted out and settled for approximately \$89 million from the same defendants, of which at least $\$ 4.3$ million came from foreign defendants; 4) The total amount recovered by private plaintiffs, all of which were direct purchasers, was approximately \$175 million; 5) The DOJ received $\$ 105.4$ million in criminal fines, of which $\$ 25.4$ million came from three foreign defendants; 7) Individuals involved in the conspiracy were fined nearly $\$ 500,000$.

In the fall of 1992, Archer Daniels Midland (ADM) executive and whistleblower Mark Whitacre began working with the FBI as a cooperating witness, using hidden tape recorders to reveal price fixing in the lysine market. While doing so, Whitacre captured Michael Andreas, vice chairman of ADM, and Terrance Wilson, head of the corn processing division, participating in price-fixing meetings concerning citric 
acid. ${ }^{146}$ On June 27, 1995, the FBI raided ADM's headquarters in Decatur, Illinois, and within days the FBI also raided several other corn-products companies, including Haarmann \& Reimer (Haarmann), Hoffman-La Roche (Roche), and Jungbunzlauer. The FBI seized thousands of incriminating documents implicating all four of these companies in a conspiracy to fix prices of citric acid. ${ }^{147}$ Several years later, in 1998, the U.S. government filed charges against a fifth company, Cerestar Bioproducts BV (Cerestar). ${ }^{148}$

Shortly after the criminal proceedings began, civil antitrust suits against ADM, Haarmann, Roche, and Jungbunzlauer were filed by hundreds of food, beverage, and chemical companies, which were consolidated in the summer of 1996 as In re Citric Acid Antitrust Litigation, MDL No. 1092, in the Northern District of California. ${ }^{149}$ These direct purchasers alleged that the conspiracy occurred from July 1991

146 Citric acid is a flavor additive and preservative produced from various sugars. It is found in soft drinks, processed food, detergents, and pharmaceutical and cosmetic products.

147 John M. Connor, What Can We Learn from the ADM Global Price Conspiracies?, Staff Paper 98-14 (August 1998), http: //www.ag.uiuc.edu/famc/program98/connor.htm.

148 U.S. Dept. of Justice, Dutch Company Charged with PriceFixing on Citric Acid, 98-298 (June 23, 1998), http:// 149.101.1.32/atr/public/press_releases/1998/1805.pdf.

149 Cargill, Inc. was also named as a defendant, but was dismissed from the class-action suit in January 1998. 
through December 1995, in which U.S. sales of citric acid ranged from $\$ 1.2$ billion to $\$ 1.45$ billion. ${ }^{150}$ Plaintiffs estimated that overcharges during this period could have been as high as \$400 million, and therefore were entitled to treble damages of nearly $\$ 1.2$ billion. ${ }^{151}$ However, in October 1996, the four defendants offered settlements in proportion to their market shares of citric acid for \$94 million.

Proctor \& Gamble, Quaker Oats, Kraft Foods, and Schreiber Cheese, four of the largest buyers of citric acid, decided to opt out of the class, and brought their own private suit against the defendants in June 1997. One month later, on July 11, 1997, the class action suit settled for a reduced amount of \$86.2 million: ADM, Haarmann, Roche, and Jungbunzlauer agreed to pay $\$ 35$ million, \$38 million, \$5.7 million, and $\$ 7.5$ million, respectively. ${ }^{152}$

In March 1998, the four opt-out firms, who purchased approximately 19-24\% of all U.S. citric acid, reached a settlement with the defendants for an estimated total of $\$ 89$

150 John M. Connor, What Can We Learn from the ADM Global Price Conspiracies?, Staff Paper 98-14 (August 1998), http: //www.ag.uiuc.edu/famc/program98/connor.htm.

151 Id.

152 Id. The settlement was reduced because the four large buyers that opted out were seeking at least \$1 billion in damages. 
million." ${ }^{153}$ This settlement "was from 2 to 3.5 times more generous than what was received by the members of the federal class less than a year before."154

In October 1996, ADM agreed to plead guilty to its involvement in the price-fixing conspiracy, which ultimately led to guilty pleas from the other major companies in early 1997. Overall, the DOJ received \$105.4 million in criminal fines, \$25.4 million of which came from foreign companies. ${ }^{155}$

153 ADM paid \$36 million. The other three defendants are not public companies under U.S. law and therefore are not required to reveal this information. However, Roche Holding's CEO, Franz Humer, stated that Roche paid \$10 million to settle the civil antitrust suit. It paid $\$ 5.7$ million to members of the federal class, leaving $\$ 4.3$ million for the opt-out firms. Also, it is believed that Unilever settled separately as well for $\$ 25$ million, but that has not been verified. John $M$. Connor, Archer Daniels Midland: Price Fixer to the World, Staff Paper 00-11 (Dec. 2000), http: //www.agribusinessaccountability.org/pdfs / 182_ADM $\div 20$ Price $\% 20$ Fixer\%20to\%20the 20 World.pdf. It is unknown how much was awarded in attorneys' fees for either the class action or the private suit.

154 "The class settlement of \$86.2 million represented an assumed overcharge of $\$ 1.7$ to $\$ 2.4$ million per percentage point of the market. However, the opt-out firms received $\$ 4.7$ to $\$ 6.0$ million per percentage point." John M. Connor, What Can We Learn from the ADM Global Price Conspiracies?, staff Paper 98-14 (August 1998), http: //www.ag.uiuc.edu/famc/program98/connor.htm.

155 ADM was fined a total of $\$ 100$ million (\$70 million for the lysine case and $\$ 30$ million for the citric acid case). Haarman, a U.S. subsidiary of Bayer AG, a foreign corporation, paid \$50 million in criminal fines, and the two Swiss companies, Roche and Jungbunzlauer, paid fines of \$14 million and \$11 million, respectively. Cerestar, a Dutch company, was fined $\$ 400,000$. U.S. Dept. of Justice, Dutch Company Charged 
According to the DOJ in 1998, the conspiracy was "one of the largest, if not the largest, conspiracies ever prosecuted by the Department of Justice."156 The companies were also fined in Canada and Europe for approximately $\$ 11.5$ million and $\$ 120.5$ million, respectively. ${ }^{157}$

Individuals from each company were also charged for their participation in the conspiracy. Although none actually went to jail, each pled guilty and paid hefty fines totaling $\$ 490,000 .{ }^{158}$

with Price-Fixing on Citric Acid, 98-298 (June 23, 1998), http:// 149.101.1.32/atr/public/press_releases/1998/ 1805.pdf.

156 John M. Connor, What Can We Learn from the ADM Global Price Conspiracies?, Staff Paper 98-14 (August 1998), http: //www.ag.uiuc.edu/famc/program98/connor.htm.

157 Harry Chandler, Cartels and Amnesty: The State of Play in Canada, Competition Bureau, http://www. competitionbureau.gc.ca/internet/index. cfm?itemID=1 $194 \& l g=e$ (April 5, 2000). CBG, European Commission Fines Five Companies in Citric Acid Cartel, http://www. cbgnetwork.org/408.html (December 5, 2001).

158 ADM's Michael Andreas and Terrance Wilson were both imprisoned and fined solely for their involvement in the lysine conspiracy. Hans Hartmann (Haarman), Udo Haas (Roche), and Rainer Bichlbauer (Jungbunzlauer) each paid $\$ 150,000$, and Silvio Kluzer (Cerestar) paid $\$ 40,000$ for their roles in the conspiracy. U.S. Dept. of Justice, Dutch Company Charged with Price-Fixing on Citric Acid, 98-298 (June 23, 1998), http://149.101.1.32/atr/public/press_releases/1998/1805.pdf. 
In re Commercial Explosives Litigation, 945 F. Supp. 1489 (D. Utah 1996).

Summary: These related cases concern an agreement between some of the largest manufacturers of commercial explosives in the world to fix prices in the sale of certain commercial explosives. They are noteworthy because: 1) the initial investigation was apparently initiated by private counsel and was later followed by a DOJ investigation; 2) There were two settlements totaling \$113 million settlement; 3 ) of this amount \$97.75 million came from foreign owned corporations, and; 4) Counsel was awarded a 30\% fee in one case; the other was confidential. ${ }^{159}$

This litigation and the government investigation that followed apparently arose out of a 1992 private civil suit initiated by Thermex Energy Corporation ("Thermex"), a Texas manufacturer of commercial explosives, against Atlas Powder Company, owned by Imperial Chemical Industries P.L.C. of Britain ("ICI"). ${ }^{160}$ Thermex brought state and federal antitrust allegations against Atlas Powder and alleged it was forced out of business for refusing to participate in a conspiracy to

159 Order Awarding Fees and Reimburse. of Expenses for Atty. Fees, Doc. 874 (Dec. 30, 1998).

160 Thermex Energy Corporation v. Atlas Powder Co. d/b/a ICI Explosives U.S.A., Inc., et al., No. 92-03-141, District Court of Wise County Texas (1992). 
monopolize a part of the commercial explosives market. ${ }^{161}$

In August 1995, a jury awarded \$488.5 million to Thermex and found that ICI had engaged in a conspiracy with Defendant Dyno Nobel's predecessor, Ireco Incorporated, "to allocate territories and fix prices."162 The case settled for a confidential amount, later reported to be $\$ 36$ million. ${ }^{163}$

In September 1995, the Department of Justice secured guilty pleas and fines for two of the defendants in the Commercial Explosives litigation, Dyno Nobel Inc., a unit of Dyno Industrier A.S. of Norway and ICI, a unit of Imperial Chemical Industries P.L.C. of Britain. ${ }^{164165}$ The Defendants were

161 ICI'S Atlas Powder Unit Seeks Bankruptcy Protection, NEW YORK TIMES (SAT. LATE ED.) Sec. 1; Page 35; Column 1, (Aug. $12,1995$.

162 Consolid. Amend. Complaint If 8 (June 14, 1996). Richard Forsythe, CEO of Thermex, commented that he's relieved the 11year order was ending and added that the verdict could trigger a ripple effect in the construction, mining and the oil and gas industries worldwide. "This decision should promote competition and hopefully lower prices for the customer." Internet Bankruptcy Library Archives, Dallas, Texas, July 14, 1995. Available at http://bankrupt.com/TCR_Public/950724.MBX

163 Business Wire (August 24, 1995), ICI Explosives USA Inc. Settles Texas Action. Available at html

164 Dyno is Fined \$15 Million in Price Fixing, THE NEW YORK TIMES (THURS. LATE ED.), Section B, Page 5, Column 1 (Sept. 7, 1995).

165 There is corroboration that the DOJ began its investigation in 1992. See www.crowell.com/content/Expertise/Antitrust/Publications22/art rrm explosi ve1098.htm 
charged with conspiring to fix the prices of commercial explosives in Kentucky, Illinois and Indiana and to eliminate competition in the sale of commercial explosives to three limestone quarries in central Texas. Dyno Nobel of Sale Lake City, pleaded guilty and agreed to pay a \$15 million fine to settle antitrust charges. This litigation brought about the largest ever fine up until that time for a single defendant in a criminal antitrust case. ICI, which was involved in the same case agreed to pay a $\$ 10$ million fine. ${ }^{166}$ By May 1997, this investigation had resulted in 14 guilty pleas by 12 corporations and two individuals, and the assessment of $\$ 37.5$ million in criminal fines. ${ }^{167}$

In February, 1996 a class action suit was brought by seventy plaintiffs representing a number of companies that purchase commercial explosives. In their complaint plaintiffs allege that the defendants engaged in an over-arching nationwide conspiracy to fix prices of commercial explosives, and that they did so by such activity as meeting with competitors to discuss and agree on prices, imposing fabricated surcharges, and retaliating against Thermex Energy

166 Id.

167 Press Release U.S. Dept. of Justice (May 30, 1997), Lacroche Industries Inc. Pleads Guilty to Price Fixing, Pays $\$ 1.5$ million. Available at http://www.usdoj.gov/atr/public/press_releases/1997/1139.htm 
Corporation, another manufacturers of commercial explosives, for refusing to cooperate in this conspiracy. The time of the conspiracy was approximately 1985 until 1993.

Another, similar, class action suit was brought in August 1996 and the two were consolidated. ${ }^{168}$ The cases then settled for approximately $\$ 77$ million by $1998 .{ }^{169}$ Attorney's fees of $30 \%$ were awarded Plaintiffs' counsel in addition to reimbursement of costs. ${ }^{170}$

168 Defendants E.I. DuPont de Nemours and Company and Austin Powder attempted to have plaintiffs' Consolidated Amended Complaint dismissed, but their requests were denied.

169 Out of this settlement, most was paid out by foreign defendants. Dyno Nobel Inc. (a unit of a Norwegian company) paid 43,750,000. Settle. Agreement of Defendant Dyno Nobel Inc. Pg. 3 (Mar. 26, 1998). ICI Explosives USA, Inc. (a unit of a British company) paid \$18 million. Settle. Agreement of Defendant ICI Explosives U.S.A. Inc., Pg. 2 (Sept. 12, 1996). DuPont paid $\$ 5,750,000$. Settle. Agreement of Defendant DuPont, Pg. 3 (Oct. 13, 1998). Austin Powder Company paid \$10 million. Settle. Agreement of Defendant Austin Powder Co., Pg. 3 (Sept. 23, 1996). Mine Equipment \& Mill Supply Co., Inc. paid $\$ 1,150,000$. Settle. Agreement of Mine Equip. \& Supplies, Pg. 3 (Dec. 31, 1997). The money was distributed to the class and in 2006 the very small amount remaining was subject to a cy pres distribution, some of which was allocated to the American Antitrust Institute.

170 Order Awarding Fees and Reimburse. Of Expenses for Atty. Fees, Doc. 874 (Dec. 30, 1998). 
Conwood Co. V. United States Tobacco Co., 290 F.3d 768 (6th Cir. 2002).

This case is noteworthy because: 1) The \$1.05 billion unanimous jury verdict represents the largest antitrust judgment ever affirmed on appeal; 2) Plaintiff's counsel survived motions for summary judgment and for judgment as a matter of law, and secured injunctive relief to prevent the defendant from further anti-competitive conduct; 3) Plaintiff is a competitor; and 4) This case is not a follow-on to any government action, rather private counsel alone initiated and obtained substantial monetary and injunctive relief.

In 1998 Conwood ("Conwood") brought an action against United States Tobacco Co. ("USTC"), its competitor in the moist snuff smokeless tobacco industry, for alleged violations of $\S 2$ of the Sherman Act, $\S 43$ (a) of the Lanham Act and various state law violations.

The moist snuff smokeless tobacco industry makes more than \$1 billion in profits each year. USTC controls 75-80\% of that market with its popular Copenhagen and Skoal brands and "has the highest profit margin of any public company in the country."171 Conwood is USTC's largest competitor with its

171 Conwood Co. V. United States Tobacco Co., 290 F.3d 768, 774 (6th Cir. 2002). 
Kodiak brand, holding approximately 13\% of the market. Swisher International and Swedish Match ("Swedish") are the only two other competitors in the industry with about four percent and six percent of the market share, respectively.

Conwood alleged that beginning in 1990 USTC sought to exclude competition in the market by pursuing anti-competitive strategies, issuing from high-level executives, including unauthorized removal and destruction of Conwood racks, and deceptive practices in category management and discount programs .

Moist snuff products are sold from gravity-fed racks, known as "facings," which dispense cans of the product and provide for point of sale advertising (POS). This method of advertising is particularly important in the moist snuff industry since the government restricts other forms of tobacco advertising, and prohibits television and radio advertising altogether. The racks are often the sole means by which a manufacturer can reach consumers and are therefore provided to retail stores by each manufacturer at no cost.

Conwood proved at trial that USTC sales representatives, at the direction of their supervisors, routinely removed Conwood and other competitors' racks, and their accompanying POS, without obtaining consent or by misrepresenting facts to retailers who were often unaware that there were multiple 
manufacturers of moist snuff products. Conwood presented testimony that USTC sales representatives stated that their bonuses were tied to the destruction of competitors' racks and POS. Once competitors' racks were removed, their products were either put in USTC racks or bagged up and left under a counter. According to Conwood's Chairman, after 1990 the company "spent $\$ 100,000$ a month on replacement racks"172 and its sales representatives spent approximately 50\% of their time repairing or replacing damaged racks.

Conwood asserted that USTC also excluded its competitors through abuse of its role as category captain, which involves store-by-store management of an entire class of products and can control the number of items a store sells. Retailers began utilizing category management in the 1990s to determine which products were more profitable and should therefore be displayed more prominently or given more shelf space. As part of the process, retailers sometimes rely on manufacturers for information on "which items to sock, consumer information, sales, and which stores are stocking what items."173 In its role as category captain, USTC supplied false information to retailers including inflated or "skewed" sales data, in order to limit the facings and POS of competitors' products,

\footnotetext{
172 Id. at 778 .

173 Id. at 776 .
} 
particularly the "price value" brands introduced by Conwood and Swedish in the mid-1990s. According to internal USTC documents, the company found it "imperative" to continue as category captain "to eliminate competitive products," and to "inhibit competitive growth. . to the best of [their] ability." ${ }^{174}$

USTC was also successful in excluding competition through its Consumer Alliance Program, which granted a discount to retailers who agreed to provide sales data and participate in promotion programs, and/or give USTC racks the best or exclusive placement. According to Conwood, this program was used in an effort to obtain exclusive vending, and according to a USTC internal document, "the elimination of competition products."175 USTC was successful in signing 37,000 retailers, representing $80 \%$ of its entire volume in moist snuff sales, in the first few months of the program.

Through these and other anticompetitive practices USTC engaged in a widespread campaign to limit the distribution of competing brands at retail outlets. These actions harmed consumers by limiting consumer choice and causing higher prices. In fact, Conwood's expert testified that "there was a

\footnotetext{
174 Id. at 777 .

175 Id. at 778 .
} 
direct relationship between the number of facings controlled by UST[C] and higher prices for consumers."176

Although Conwood's market share did increase 2.5\% between 1990 and 1998, there was evidence that its share was lower than its national average in locations where USTC had rack exclusivity and higher for those locations where USTC had not obtained such exclusivity, and that its share would have increased 6.5 to 8.1 percent ${ }^{177}$ had USTC not engaged in anticompetitive behavior. According to Conwood's expert this disparity was caused by USTC's exclusionary practices and resulted in between $\$ 313$ million and $\$ 488$ million in damages. ${ }^{178}$

USTC did not challenge that it had monopoly power and asserted that this power was a result of a superior product, rather than an exercise of monopoly power. The company defended that Conwood's evidence of destroyed and discarded racks supported isolated sporadic torts rather than antitrust

176 Conwood Co. V. United States Tobacco Co., 2000 U.S. Dist. LEXIS 12797, 12 (W.D. Kent. August 10, 2000).

177 Conwood's expert testified that where "Conwood had a market share in 1990 of 20 percent or more, the market share grew on average an addition 8.1 percent. . . [and] where Conwood's market share in 1990 was at least 15 percent, it grew an additional 6.5 percent." Conwood Co. V. United States Tobacco Co., 290 F.3d at 780 .

178 Id. at 780 . 
violations, and that its actions as category captain were merely aggressive competition and common practice. ${ }^{179}$

Before going to trial plaintiff's counsel successfully defended motions to exclude Conwood's expert testimony and separately, the damages study, and also won on USTC's motion for summary judgment. The case then went to trial in February 2000 with both parties agreeing to dismiss their respective Lanham Act claims and Conwood dismissing its state law claims before going to the jury. After just four hours of deliberation the jury returned a \$350 million verdict for Conwood and ruled in favor of Conwood on USTC's counterclaims for conversion and Sherman Act violations.

Plaintiff's counsel also prevailed in its subsequent motion for injunctive relief to prevent USTC from removing competitors' racks and POS without obtaining the retailer's prior consent and successfully defended USTC's motion for judgment as a matter of law. After trebling, the total amount of damages awarded was \$1.05 billion, the largest antitrust judgment ever affirmed on appeal. In reviewing the judgment, district court Judge Thomas B. Russell stated that the award was "well within the range that Conwood proved at trial."180

179 See Final Brief for Appellants at page 5. 180 Conwood Co. V. United States TobacCo Co., 2000 U.S. Dist. LEXIS at 16 . 
In re Dynamic Random Access Memory (DRAM) Antitrust

Litigation, Master File No. M-02-1486PJH, MDL No. 1486.

This case is noteworthy because: 1) The $\$ 325,997,000$

settlement represents more than $85 \%$ of the alleged pre-trebled damages; ${ }^{181} 2$ ) Of this total, $\$ 310,997,000$ was recovered from foreign cartelists; 3) The direct purchaser action ${ }^{182}$ was filed shortly after a federal grand jury issued subpoenas to various DRAM manufacturers; $\left.{ }^{183} 4\right)$ Class Counsel cooperated with the Department of Justice to obtain documents already produced in the grand jury investigation; and 5) Class Counsel negotiated a successful settlement despite many of defendants' key employees invoking their Fifth Amendment privilege against self-incrimination as a result of the Department of Justice investigation, and were awarded a 25\% attorneys fee.

181 This percentage, 85\% of the pre-trebled damages, is based on damages as alleged by Plaintiffs. Memorandum of Points and Authorities in Support of Attorneys' Fees, Expenses \& Incentive Awards, FN 5, In re Dynamic Random Access Memory (DRAM) Antitrust Litigation, Master File No. M-02-1486PJH, MDL No. 1486 .

182 An indirect purchaser action is still pending. See In re Dynamic Random Access Memory Antitrust Litigation, 2007 U.S. Dist. LEXIS 44254 .

183 "The three largest chip makers said that they had been subpoenaed or informally contacted in recent days by the Justice Department" as part of an industry-wide antitrust investigation. Barnaby J. Feder, Chip Makers Report Inquiry on Industry, The New York Times C1 (June 20, 2002). 
Dynamic random access memory ("DRAM") is an electronic microchip used in everyday electronics, including personal computers, printers, digital cameras and cell phones, and is sold in two forms and a variety of densities, speeds, and frequencies. ${ }^{184}$ DRAM manufacturers sell to both large and small-scale customers ${ }^{185}$ through a variety of channels and using at least two pricing methods. ${ }^{186}$ In the year leading up to the alleged anticompetitive conduct, the \$11.2 billion industry sustained significant losses due to waning sales in the personal computer market, causing manufacturers to lose money on "every DRAM they made."187 However, prices for DRAM components and modules rose from approximately \$1 per in December 2001 to between $\$ 4$ and $\$ 5$ per by the end of May $2002 .{ }^{188}$

184 In re Dynamic Random Access Memory Antitrust Litigation, 2006 U.S. Dist. LEXIS 39841 at 21.

185 Purchasers include equipment manufacturer customers, franchise distributors, smaller-volume customers, and those who purchased through defendant Micron's online DRAM sales. In re Dynamic Random Access Memory Antitrust Litigation, 2006 U.S. Dist. LEXIS 39841 at 22-23.

186 All defendants use contract and spot pricing, "while defendant Micron additionally engages in direct sales to customers through its [online] division." Id. at 23.

187 Barnaby J. Feder, Chip Makers Report Inquiry on Industry, The New York Times C1 (June 20, 2002).

188 Id. 
A federal grand jury sitting in the Northern District of California began investigating several DRAM manufacturers in June 2002 for antitrust violations. ${ }^{189}$ Shortly thereafter, on June 21, 2002, direct purchasers filed suit against the leading manufacturers ${ }^{190}$ for violations of section 1 of the Sherman Act. Specifically, the complaint alleged that during the period April 1, 1999 through June 30, 2002, defendants engaged in an international conspiracy to fix, raise and maintain prices for DRAM, causing purchasers to pay artificially inflated prices. ${ }^{191}$

The direct purchaser class faced significant hurdles throughout the course of the litigation. First, on October 16, 2002, the Department of Justice (DOJ) moved to stay all discovery pending its grand jury investigation. While

189 See U.S. V. Censullo, No. CR 030368 PJH, paragraph 3 (N.D. Cal. Dec. 17, 2003).

190 Defendants' market share was more than 70\% during the class period. In re Dynamic Random Access Memory Antitrust Litig., 2006 U.S. Dist. LEXIS 39841, 21 (N.D. Cal. June 5, 2006). Defendants include Elpida Memory, Inc., Hynix Semiconductor, Inc., Infineon Technologies AG, Micron Technology Inc., Mosel Vitelic Corporation, Nanya Technology Corporation, NEC Electronics America, Inc., Samsung Semiconductor, Inc., Samsung Electronics Co., Ltd., Winbond Electronics Corporation, and their U.S. subsidiaries. See Third Consolidated Amended Complaint, In re Dynamic Random Access Memory (DRAM) Antitrust Litigation, Master File No. M-02$1486 \mathrm{PJH}, \mathrm{MDL}$ No. 1486.

191 Third Consolidated Amended Complaint. 
numerous agreements resulted in production of documents by defendants on a rolling basis, merits discovery did not begin until July 14, 2005. ${ }^{192}$ During the course of the litigation Class Counsel ultimately reviewed and analyzed more than 4.5 million pages of documents, participated in 129 depositions around the world, and defended against repeated motions to compel and five separate motions for summary judgment. ${ }^{193}$ Perhaps Class Counsel's greatest success was certifying the class on June 5, 2006, despite defendants' vigorous argument that typicality could not be met given the different types of DRAM, different categories of customers, and different channels though which plaintiffs purchased DRAM. ${ }^{194}$ Class Counsel also had to contend with the ramifications of 16 of defendants' key employees invoking their Fifth Amendment

192 See Memorandum of Points and Authorities in Support of Attorneys' Fees, Expenses \& Incentive Awards. The parties stipulated to production by Defendants, on a rolling basis, of all documents produced to the grand jury, and Plaintiffs agreed to wait to take depositions and make interrogatory requests. The DOJ renewed its request for a stay of deposition and interrogatory discovery in July 2004 and again on January 20, 2005. "On July 14, 2005, Class Counsel worked with Defendants and the DOJ to come up with an agreement whereby merits discovery could finally begin." Id.

193 Memorandum of Points and Authorities in support of Attorneys' Fees, Expenses \& Incentive Awards, page 11-12.

194 Order Granting Motion for Class Certification, pages 31-32, In re Dynamic Random Access Memory (DRAM) Antitrust Litigation, 2006 U.S. Dist. LEXIS 39841. 
privilege against self-incrimination due to the continuing DOJ investigation. ${ }^{195}$

The parties began settlement discussions in 2004, with several partial settlements occurring between 2004 and 2007 . Seven of the nine defendants settled prior to February 20, 2007, when the Court ruled on four of defendants' summary judgment motions. ${ }^{196}$ The remaining two defendants settled only after mediation, and just one month before the case was set to go to trial in April 2007. ${ }^{197}$

On August 15, 2007, Judge Phyllis Hamilton granted Class Counsel's request for attorneys fees in the amount of 25\% of the settlement, plus expenses and incentive awards for the ten

195 As of March 7, 2007 the DOJ investigation has resulted in more the $\$ 732$ million in fines, and criminal charges against four companies and 18 individuals. See statement of Thomas 0. Barnett Assistant Attorney General Antitrust Division: Before the Subcommittee on Antitrust, Competition Policy and Consumer Rights Committee on the Judiciary United States Senate, March 7, 2007, available at: http://www.usdoj.gov/atr/public/testimony/221777.htm.

196 Memorandum of Points and Authorities in Support of Attorneys' Fees, Expenses \& Incentive Awards, page 11-12. The Court ruled on four of defendants' motions for summary judgment, denying all but one, resulting in the dismissal of defendant Nanya's foreign parent corporation and Taiwan subsidiary, but keeping in Nanya's American subsidiary.

197 The defendants settled with plaintiffs as follows: Infineon $\$ 20,750,000$; Samsung $\$ 67,000,000$; Hynix $\$ 73,000,000 ;$ Elpida $\$ 14,750,000 ; \operatorname{NEC} \$ 35,960,000 ;$ Micron $\$ 90,537,000 ;$ Winbond $\$ 2,000,000 ;$ Mosel $\$ 15,000,000 ;$ and Nanya $\$ 7,000,000$. See Memorandum of Points and Authorities in Support of Attorneys' Fees, Expenses \& Incentive Awards, page 16. 
Class Representatives in the amount of $\$ 10,000$ each. ${ }^{198}$ In granting the \$81 million award, Judge Hamilton praised Class Counsel for "an exceptional job" coordinating and litigating the case, and stated, "I have cases a fraction the size of this one that take up more of my time, just because counsel are not acting as cooperatively and professionally as you are." 199

198 Matthew Hirsch, DRAM Case Yields \$81 Million Fee Award, The Recorder (August 16, 2007) available at: http: //www.law.com/jsp/article.jsp?id=1187168529608. Judge Hamilton did take $\$ 20,000$ off of the $\$ 4.2$ million in requested expenses, due to some airfare and meals that "gave her some concern."

199 Id. 
Natural Gas Antitrust Cases I, II, III \& IV. Sweetie's, V. EI Paso Corporation, No. 319840 (S.F. Super. Ct.); Continental Forge Company $v$. Southern California Gas Co., No. BC237336 (L.A. Super. Ct.); Berg V. Southern California Gas Co., No. BC241951 (L.A. Super. Ct.); City of Long Beach V. Southern California Gas Co., No. BC247114 (L.A. Super. Ct.); City of L.A. V. Southern California Gas Col, No. BC265905 (L.A. Super. Ct.); Phillip v. El Paso Merchant Energy LP, No. GIC 759425 (San Diego Super. Ct.); and Phillip v. El Paso Merchant Energy LP, No. GIC 759426 (San Diego Super. Ct.). (El Paso)

This settlement positively exemplifies private class action enforcement of antitrust violations because: (1) Approximately thirteen million California consumers and three thousand businesses ${ }^{200}$ benefited from the settlement; ${ }^{201}$ (2) The settlement consideration consisted of more than $\$ 1.552$ billion, ${ }^{202}$ including $\$ 551$ million in upfront cash and stock valued at market rates, \$876 million in semi-annual cash payments, and $\$ 125$ million in rate reductions on electricity, ${ }^{203}$ a total settlement consideration which at the

200 Ruling Following Oral Argument, 1, (Dec. 5, 2003).

201 The class consisted almost entirely of indirect purchasers. 202 After disbursement to city and states and compensation for attorney's fees, the class will receive more than $\$ 1.4$ billion. Ruling, 2 .

203 The upfront payment included cash totaling over $\$ 323.8$ million and stock worth over $\$ 227.5$ million at market rates at the time of the settlement, for a combined value of slightly over $\$ 551$ million. The semi-annual payments are to be paid out over 15 or 20 years, depending on El Paso's credit rating. In regard to the $\$ 125$ million reduction of the price paid for electricity, El Paso lowered its prices to the California Department of Water Resources and class members received the benefit in the form of reduced natural gas bills. Ruling, 2 . 
time resulted in the "largest antitrust class action settlement in California history;"204 (3) The recovery was significantly larger than the profit earned by the illegal overcharge and a substantial proportion of the damages allegedly caused by the conduct at issue; ${ }^{205}$ (4) Attorneys' fees composed only 6\% of the settlement-date ${ }^{206}$ total recovery; ${ }^{207}$ (5) Because of private counsel's efforts, the California Attorney General's office chose not to pursue the defendants independently; ${ }^{208}$ and (6) The defendants' conduct increased prices significantly for more than six years. ${ }^{209}$ Private plaintiffs first filed natural gas antitrust actions in California Superior Court in september 2000, the same year that California Attorney General Bill Lockyer began

204 Ruling, 1.

205 "The [\$1.5 billion] settlement is also extraordinary in relationship to the $\$ 184$ million in profits reportedly earned by [defendant] El Paso Merchant Energy on the pipeline capacity it purchased." Ruling, 4.

206 The Amended Judgment, Final Order, and Decree Granting Final Approval to the Class Action Settlement, 6 (Dec. 10, 2003), estimated the present value at approximately \$1 billion.

207 \$60 million.

208 "Except as a vehicle to implement the structural relief terms of this settlement." MPA ISO Motion for an Award of Attorney's Fees and Reimbursement of Costs, 11 (Nov. 6, 2003). $20909 / 01 / 1996-03 / 20 / 2003$. 
investigations under his Energy Task Force. ${ }^{210}$ Defendants, including El Paso and its subsidiaries ("El Paso") 211 and Sempra, removed to federal court, though the federal court later remanded to state court. The California Judicial Council next coordinated the cases in the San Diego Superior Court under Coordination Trial Judge Richard Haden. In May 2002, Judge Haden ordered that the cases be divided into Northern and Southern California tracks.

Plaintiffs in Northern and Southern California then filed two separate complaints against the defendants. The Northern California Plaintiffs alleged that El Paso and its subsidiaries entered into self-dealing in, or manipulation of, the price of natural gas in California. ${ }^{212}$ Northern California

210 Brooks, Nancy Rivera, "Lockyer's Goal Is to Make Them Pay; While U.S. seeks convictions, California has settled with energy suppliers, winning nearly \$450 million," Los Angeles Times, Business, Part 3, 6, Home Ed. (Dec. 2, 2002).

211 El Paso consists of El Paso Pipeline and El Paso Merchant. Both have several subsidiaries. MPA ISO Plaintiffs' Motion for Preliminary Approval of Class Action Settlement, 5 (May 8 , 2003 ).

212 El Paso Natural Gas ("Natural Gas") acquired additional pipeline capacity-enough to meet one-sixth the daily requirement for natural gas in California-for gas traveling to California. The El Paso companies decided to engage in a sham open bidding process in February 2000, and Natural Gas announced it would only accept bids over $\$ 37.5$ million for the entire capacity. Another El Paso subsidiary, El Paso Merchant ("Merchant"), was the only bidder for the entire capacity, offering \$38.5 million. Unknown to other bidders, Mojave Pipeline, another El Paso subsidiary, had agreed to give 
Plaintiffs, overcoming challenges to their actions, ultimately proceeded on an intra-corporate conspiracy claim. ${ }^{213}$ The Southern California Plaintiffs alleged that El Paso and Sempra "participated in a conspiracy to eliminate competition, preserve and maintain their market power, artificially constrain supplies of natural gas, and exploit the deregulation of the electricity industry for their illicit gain." ${ }^{214}$ Plaintiffs proceeded with their actions after the

Natural Gas a secret discounted rate for its downstream transportation costs. Thus, the discounted transportation rate allowed Natural Gas to bid high for the capacity. Once Natural Gas won the capacity, El Paso had firm-wide capacity rights to transport "an enormous amount of the total capacity," allowing El Paso to "manipulate the market and raise prices to class members." MPA ISO Plaintiffs' Motion for Preliminary Approval of Class Action settlement, 7. Merchant overbooked delivery of natural gas into California on the pipeline and allowed its gas to flow, while denying longterm customers delivery. Merchant forced those shorted customers, still needing to supply their customers, to buy gas in the spot markets. During this time, El Paso sold in the spot market at inflated prices, "unlawfully [tying] the purchase of gas transportation services to the purchase of the natural gas." Id. at 8 .

213 Declaration of Bill Lockyer, 3 (November 5, 2003). "Defendants unlawfully tied the purchase of gas transportation services to the purchase of natural gas." MPA ISO Plaintiffs" Motion for Final Approval of Class Action Settlement, 5, citing Nor. Cal. Compl. I\$195-202.

214 MPA ISO Plaintiff' Motion for Final Approval of Class Action settlement, 5. In the early 1990s, changes in the law allowed pipelines outside California to deliver gas to California, eliminating the monopolies of Southern California Gas Company ("SoCal Gas") and San Diego Gas \& Electric ("SDG\&E"). In 1992, Tenneco finished a pipeline that partially bypassed SoCal Gas and SDG\&E and began planning new 
Federal Energy Regulatory Commission (FERC) finding that El Paso had "violated FERC's affiliate rules, substantially injuring California consumers" ${ }^{215}$ when it falsely reported its natural gas sales to the trade press to influence published natural gas prices. ${ }^{216}$ The claims included allegations of conduct that would ordinarily be subject to the per se rule under the Cartwright Act, the California antitrust statute. ${ }^{217}$ The settlement resolved the claims against El Paso. After three years of substantial investigation, discovery ${ }^{218}$ and litigation, the court approved the parties'

pipelines that would entirely bypass the SoCal Gas and SDG\&E. In 1996, El Paso acquired Tenneco. The plaintiffs alleged that in september 1996, El Paso, SoCal Gas and SDG\&E secretly met and agreed not to compete with each other in California and to increase their stranglehold on the Southern California market. El Paso agreed to abandon Tenneco's projects intended to circumvent SoCal Gas and SDG\&E. In exchange, SoCal Gas and SDG\&E agreed to stop competing with El Paso on pipeline project in Mexico. The agreement left SoCal Gas and SDG\&E without competition.

215 Declaration of Bill Lockyer, 2 .

216 FERC confirmed this conduct. See Final Report on Price Manipulation in Western Markets, Fact-Finding Investigation of Potential Manipulation of Electric and Natural Gas Prices, at III-12-15 (March 2003), quoted in MPA ISO Plaintiffs' Motion for Preliminary Approval of Class Action settlement, 11. 217 The court did not rule on whether the conduct at issue was per se illegal, subject to the rule of reason, or some combination of the two.

218 Plaintiffs' discovery included reviewing over $1,650,000$ pages of documents and 30,000 electronic files. Ruling, 6 . 
settlement in December 2003. ${ }^{219}$ The settlement class $^{220}$ (the "Class") consisted of California purchasers of natural gas for consumption, but not for resale or generation of electricity for resale, between September 1, 1996 and March 20, 2003. ${ }^{221}$ Three subclasses existed within the Class: (1) Core Natural Gas Subclass; (2) Non-Core Natural Gas Subclass; and (3) Electricity Subclass. The Core Natural Gas Subclass consisted of core subscribers of at least one California natural gas utility. The Non-Core Natural Gas Subclass was non-core subscribers of at least one California natural gas utility. The Electricity subclass included purchasers of electricity from any California public utility. Government entities, including federal and state agencies, cities, counties and other municipalities, were excluded from the class. ${ }^{222}$

219 Id. Ruling Following Oral Argument, entered Dec. 5, 2003. Amended Judgment, Final Order, and Decree Granting Final Approval to the Class Action Settlement, entered Dec. 10, 2003 .

220 See Amended Judgment, Final Order, and Decree Granting Final Approval to the Class Action Settlement, 5 (Dec. 10, 2003) (certifying the class and subclasses for the settlement).

221 Amended Judgment, Final Order, and Decree Granting Final Approval to the Class Action Settlement, 2-3. The class consisted almost entirely of indirect purchasers.

222 Id. at 3 . 
The total recovery of $\$ 1.55$ billion was significantly larger than the profit earned by El Paso's illegal overcharge and a substantial proportion of the alleged damages caused by the defendants' conduct. ${ }^{223}$ After deducting attorneys' fees, litigation expenses, and payments to various state and city governments, the settlement provided a net of $\$ 1.4$ billion ${ }^{224}$ to the Class including $\$ 481$ million in upfront cash and cash equivalent, ${ }^{225} \$ 799$ million in semiannual payments ${ }^{226}$ and a $\$ 125$

223 "The [total] settlement is also extraordinary in relationship to the $\$ 184$ million in profits reportedly earned by El Paso Merchant Energy on the pipeline capacity it purchased." Ruling, 4. The exact correlation between the settlement and El Paso's profit is unclear, as \$184 million is only the profit El Paso Merchant made by purchasing pipeline capacity and does not include other potential sources of profit, e.g., how much El Paso might have gained by eliminating competing pipeline projects into Southern California. The alleged damages were significantly larger, as the conduct at issue allegedly cause a general increase of prices for gas and electricity in California.

224 Amounts received by non-Class plaintiffs, attorneys' fees and litigation expenses of the utilities and California governmental parties account for the deductions from the full amount. Ruling, 2. The payments to non-Class plaintiffs provided compensation to the states of Nevada, Oregon, and Washington, and to the cities of Los Angeles and Long Beach.

225 The upfront cash equivalent consisted of the proceeds of the sale of El Paso common stock. Id. Again, the $\$ 481$ million is the net amount paid to the class, after deducting payments for non-Class plaintiffs, attorneys' fees and the litigation expenses of the utilities and California governmental parties. The $\$ 481$ million is based on the value of the stock at the time of the settlement, which was slightly over $\$ 227$ million. 
million reduction of the price paid for electricity. ${ }^{227}$ Regarding the price reductions, to avoid performing "'any sort of 'true-up' of the allocation in place at the time'" of the overcharge, the California Public Utilities Commission ("CPUC") found that the only efficient manner to distribute the settlement funds was to adjust current gas rates upon receipt of the funds. ${ }^{228}$ Class member payout by check was unsatisfactory because of the substantial administrative cost to maintain mailing addresses and print checks. ${ }^{229}$

Counsel received the full fee award they requested-which amounted to $6 \%$ of the settlement-date value of the total settlement. ${ }^{230}$ The Court approved a 3.32 multiplier of Southern California counsel's $\$ 16$ million in costs and fees, ${ }^{231}$ granting \$50 million. "Such a fee request," the Court noted,

226 The $\$ 799$ million is the amount the class will receive over a 15 or 20 year period, after deducting amounts paid to nonclass members, including to Nevada, Oregon, Washington, Los Angeles and Long Beach.

227 Id.

228 Id. at 9.

229 Id.

230 The Amended Judgment, Final Order, and Decree Granting Final Approval to the Class Action settlement estimated the present value at approximately \$1 billion. Id. at 6 . This evaluation was based on the value of the stock at the time of the settlement, which was slightly over \$227 million.

231 Costs of $\$ 1,380,752.14$ and fees of $\$ 15,072,831$. Id. 
"would be one of the lowest fees requested and granted in a common fund settlement of this magnitude," ${ }^{232}$ especially given that the "risks faced by plaintiffs" attorneys were enormous." ${ }^{233}$ Northern California counsel requested a 4.58 multiplier for $\$ 2$ million in costs and $\mathrm{fees}^{234}$ and received $\$ 10$ million. In addition, the Court lauded counsel because "[h]ere an exceptional benefit was achieved, even though plaintiffs' counsel had significant contingent risk."235

The settlement provided consumers with certain and longterm monetary benefits. For instance, "[the settlement] contains significant structural benefits that will assure more plentiful and affordable gas to Californians for decades." 236 California Public Utilities Commission "not only approved [the settlement] but. . guaranteed ratepayers will receive 100 percent of the benefit of the $[\$ 125$ million electricity] rate

232 Id. at 11. The Court reiterated that Southern California counsel's "requested five (5) percent fee is low when contrasted with customary contingent agreements in class action cases." Id. at 12 .

233 Id. at 11.

${ }^{234}$ Costs of $\$ 473,568$ and fees of $\$ 2,079,474$. Id. at 13 .

235 Id.

236 Id. at 1 . 
reductions over 15 to 20 years."237 The reach of the settlement is also impressive, given that "[e]very California consumer and business that purchases natural gas and/or electricity will benefit from this settlement in the form of rate relief." ${ }^{238}$

Consumers also benefited by the settlement's deterrent effect. The settlement imposed a "significant deterrent benefit and require[d] El Paso to implement an antitrust compliance program."239 More broadly, "the settlement amount serves as a strong deterrent to industries who believe they can engage in antitrust activities with impunity."240 "In sum," the Court concluded, "the settlement confers a substantial benefit on the class as a whole [and] is an outstanding result in a case that may be challenging to prove at trial... . ${ }^{241}$

These important benefits resulted directly from private enforcement of El Paso's alleged antitrust violations. Though

237 Id. at 2. These rate reductions provide compensation in addition to the upfront cash and stock proceeds and the semiannual cash payments.

238 Id. at 4 .

239 Id. at 1.

240 Id. at 12.

241 Id. at 4 . 
the "California Attorney General's office investigated El Paso for over two years, they never filed a case... ." ${ }^{242}$

California Attorney General Bill Lockyer noted that while FERC in 2002 found that El Paso had violated FERC's rules, FERC's outcome "did not provide the same opportunities for relief" as the private actions filed. ${ }^{243}$ "Class counsel," ${ }^{244}$ Lockyer stated, "were crucial to bringing [the settlement] to fruition." 245

242 MPA ISO Motion for an Award of Attorney's Fees and Reimbursement of Costs, 11 (Nov. 6, 2003). The California Attorney General's office became aware of the El Paso situation during an on-going investigation into higher gas costs commenced in the summer of 2000. Declaration of Bill Lockyer, 1 .

243 Declaration of Bill Lockyer, 2 .

244 Lockyer also noted that "[C]ounsel for both the Southern California Plaintiffs and the Northern California Plaintiffs were well-financed and expert litigators, bringing particular credibility to the [settlement] negotiations." Id. at 4.

245 Id. at 4 . 
In re Flat Glass Antitrust Litigation, MDL 1200, Master Docket Misc. 97-0550 (W.D. Pa.)

In re Flat Glass Antitrust Litigation is significant for a number of reasons: (1) the Federal Government had initiated an investigation into price-fixing in the flat glass industry, but no indictments were ever issued nor any government civil proceedings commenced against any company or individual;

(2) one of the defendants had applied for leniency under the DOJ's Corporate Leniency Program, but its application was rejected; (3) plaintiffs successfully appealed to the Third Circuit from the district court's grant of summary judgment in favor of the sole remaining defendant ${ }^{246} ;$ (4) settlements in the litigation, to direct purchasers, ultimately totaled \$121.7 million, $\$ 37.7$ million of which came from foreign corporations or wholly-owned US subsidiaries of foreign corporations ${ }^{247} ;$ (5) plaintiffs' attorneys' fees averaged 32\% (33 1/3\% from settlements with some defendants and $30 \%$ from the settlement with another)".

Beginning in July 1997, numerous lawsuits were filed in various district courts against six manufacturers of glass

246 See 385 F.3d 350 (3d Cir. 2004).

247 \$17.9 million came from Libbey-Owens-Ford Co, Inc. and Pilkington, and $\$ 19.8$ million came from AFG Industries Inc. a wholly-owned subsidiary of Asahi Glass Co., a Japanese corporation. 
products sold in the United States: Libbey-Owens-Ford Co, Inc. ("LOF") (now know as Pilkington North America); its parent, Pilkington plc, ("Pilkington") a United Kingdom corporation; AFG Industries, Inc. ("AFG"), a wholly-owned subsidiary of Asahi Glass Co, a Japanese corporation ; Guardian Industries Corp. ("Guardian") ; Ford Motor Company ("Ford"); and PPG Industries, Inc. ("PPG"). All of the lawsuits were subsequently consolidated by the Judicial Panel on Multidistrict Litigation in the United States District Court for the Western District of Pennsylvania before then Chief Judge Donald E. Ziegler. The cases were filed after two former senior executives of LOF made disclosures in an unrelated criminal case against them, that there had been a marketwide price-fixing conspiracy in the flat glass industry. It was later revealed that LOF had applied for leniency under the DoJ's Corporate Leniency Program, but was turned down. It was also later revealed that the DoJ had initiated two grand jury investigations into anticompetitive conduct in the flat glass industry, but no person or entity was ever indicted or charged.

On February 27, 1998, plaintiffs filed an Amended Complaint alleging that defendants had engaged in a classic, per se, horizontal conspiracy to fix, raise and maintain the price of flat glass products and automobile replacement glass 
("ARG") sold in the United States from August 1991 through December 1995. It was also alleged that, as a result of the defendants' conspiracy, members of the Class paid higher prices than they would have paid absent the conspiracy. By Orders dated November 5, 1999 and February 16, 2000, and in a decision reported at In re Flat Glass Antitrust Litigation, 191 F.R.D. 472 (W.D. Pa. 1999), the Court certified the Class. Following arm's length settlement negotiations, plaintiffs reached settlement agreements on behalf of the Class with five of the six defendants: LOF/Pilkington (\$17.9 million), AFG (\$19.8 million), Guardian (\$16.9 million), and Ford (\$8 million), for a total of $\$ 61.7$ million. Following Court approval of the settlements, plaintiffs filed an application for fees and reimbursement of expenses and the court awarded attorneys' fees of $331 / 3 \%$

After the conclusion of merits discovery, PPG, the sole non-settling defendant, moved for summary judgment. In May 2003, in an unreported decision the District Court granted summary judgment to $\mathrm{PPG}^{248}$ The Court held that the record, considered as a whole, "though it undoubtedly evidences that several of the settling defendants conspired to fix prices [of flat glass products], does not tend to exclude the possibility 248 . In re Flat Glass Antitrust Litig., Misc. No. 97-550, Opinion (W.D. Pa. May 29, 2003). 
that PPG acted independently and therefore does not support a reasonable inference that $P P G$ was involved in a price fixing conspiracy." ${ }^{249}$

Plaintiffs appealed the District Court's summary judgment ruling and on september 29, 2004, the Third Circuit issued its opinion, In re Flat Glass Antitrust Litig., 385 F.3d 350 (3d Cir. 2004). The Court of Appeals reversed the district court's grant of summary judgment as to the conspiracy to fix prices of flat glass products. ${ }^{250}$ Among other things, the Third Circuit rejected PPG's contention that the court should look at each piece of evidence separately to see if it was as consistent with the absence of a price fixing conspiracy, and found that, considered as a whole, there was sufficient evidence that PPG conspired with the settling defendants to fix the prices of flat glass products to create a question of fact for the jury, and remanded the case for further proceedings. ${ }^{251}$ Thereafter, a trial date was set and the

\footnotetext{
249 Id. at 40 .

250 The Third Circuit affirmed the grant of summary judgment as to the ARG conspiracy. Id. at 369-70.

251 Id. At 368-69. After the Third Circuit's decision, PPG filed petitions for rehearing, for a stay of the mandate, and for certiorari to the United states supreme court. These petitions were denied. See In re Flat Glass Antitrust Litigation, 115 Fed. Appx. 570 (3d Cir. 2004); PPG Industries Inc. V. Nelson, 125 S. Ct. 1699 (2005).
} 
parties prepared the case for trial. The parties exchanged lists of proposed trial exhibits and deposition designations, proposed jury instructions and voir dire questions, and filed 15 in limine motions. During this period of intense trial preparation, settlement negotiations between the parties were undertaken and in October 2005, virtually on the eve of trial, a settlement agreement was reached with PPG for \$60 million, an amount nearly equal to the total of the settlements with all of the other defendants combined. After notice and a hearing, the district court approved this settlement, and granted plaintiffs' application for attorneys fees of $30 \%$ of this settlement fund.

Both Chief Judge Ziegler and Chief Judge Ambrose (to whom the case was reassigned after Judge Ziegler's retirement) made statements about the quality of plaintiffs' counsels' legal representation at the time of the award of attorneys' fees and expenses. At a hearing on May 28, 2003 Judge Ziegler, in awarding fees of $1 / 3$ of the $\$ 61.7$ million settlements with all defendants except PPG said: "Next, we have carefully reviewed the counsel fee request of class counsel and find that the requested contingent of $331 / 3$ percent and the sums to be distributed to class counsel, including for expenses, are not only fair, reasonable, and appropriate, but the fees are modest when the court considers the stature of class counsel 
and the relief obtained for the class in this case and under the circumstances."252 Similarly, Chief Judge Ambrose, in approving the requested fee of $30 \%$ of the $\$ 60$ million settlement with PPG stated: "Well, I find that the request from plaintiffs for an award of attorneys' fees and reimbursement of expenses is reasonable, considering the skill and efficiency of counsel in obtaining this result, the complexity and duration of the litigation, the risks undertaken by plaintiffs' counsel and the time and effort devoted by them." 253

Thus, in this case, where there were (a) no governmental criminal or civil proceedings, (b) a grant of summary judgment against plaintiffs and reversal on appeal, and (c) nearly completed trial preparations, total attorneys fees amounted to slightly less than one-third of the settlements combined. Moreover, purchasers of flat glass received distributions from the settlement funds equal to approximately $2.1 \%$ of their total purchases of flat glass during the relevant period, which was a significant percentage of the alleged overcharge.

252 Transcript of May 28, 2004 at 9.

253 Transcript of Feb. 3, 2006 at10. 
In Re: Fructose Antitrust Litigation, M.D.L. File 1087, Master File \# 94-1577 (Michael Mihm) (C.D.Ill. 1995)

The Fructose Antitrust Litigation is an important example of private antitrust litigation because: (1) while the government convened a grand jury to investigate price fixing among the major manufacturers of fructose, no indictments were brought, even though indictments were brought against the major manufacturers of two related products, lysine and citric acid; (2) notwithstanding the absence of an indictment, after 10 years of litigation, including three appeals to the seventh Circuit Court of Appeals and two petitions to the supreme Court for writs of certiorari, the case settled for $\$ 531$ million, one of the largest antitrust class action settlements ever achieved; (3) Of this amount, \$100 million came from a foreign corporation, A.E. Staley Manufacturing; (4) due to the relatively small number of fructose purchasers, the payments to individual absent class members were very large in excess of \$10 million per class member in some instances; (5) each of the three appeals to the Seventh Circuit court of Appeals ${ }^{254}$ resulted in a significant ruling relating to antitrust law in particular, and civil conspiracy in

254216 F. 3d 621 (7th Cir. 2000); 295 F. 3d 651 (7th Cir. 2002); 361 F. 3d 459 (7th Cir. 2004). 
general; and (6) the presiding judge repeatedly praised the skills and conduct of the class counsel.

In 1995, following a well-publicized FBI raid at the Decatur, Illinois headquarters of Archer Daniels Midland Company, a number of antitrust class action suits were filed against manufacturers of 3 products: fructose, lysine, and citric acid. The cases were all sent to the Judicial Panel on Multi-District Litigation, which in turn separated the cases by product, transferring them to different judicial districts for consolidated and coordinated pretrial discovery. The Fructose cases were transferred to the United States District Court for the Central District of Illinois. ${ }^{255}$

Although grand jury investigations were conducted with respect to the manufacture and sale of fructose, citric acid, and lysine, indictments were issued only with respect to citric acid and lysine. Guilty pleas were entered by manufacturers and their agents relating to citric acid and

255 The Citric Acid cases were transferred to the United States District Court for the Northern District of California, and the Lysine cases were transferred to the United States District Court for the Northern District of Illinois. In Re Amino Acid Lysine Antitrust Litigation, et al., 910 F.Supp.966 (J.P.M.L. 1995) 
lysine. ${ }^{256}$ Given the fact that a final judgment in a criminal proceeding to the effect that a defendant has violated the antitrust laws, is prima facie evidence of violation of the antitrust laws in a related civil case, ${ }^{257}$ as could have been expected, class action settlements were entered into, in relatively short order, in both the Citric Acid Antitrust Litigation ${ }^{258}$ and the Lysine Antitrust Litigation. ${ }^{259}$

In contrast, no guilty pleas were entered into by any manufacturer of fructose. ${ }^{260}$ Indeed, Archer Daniels Midland Company, while entering a guilty plea with respect to citric acid and lysine, and agreeing to pay a then-record \$100 million fine, did not enter a plea with respect to fructose.

${ }^{256}$ In addition, after trial, convictions were obtained against certain officers of Archer Daniels Midland Company relating to lysine and citric acid.

25715 U.S.C. $\$ 16$

2581997 WL 446241 (N.D. Cal. 1997); 1997 WL 446240 (N.D. Cal. 1997); 1997 WL 446242 (N.D. Cal. 1997); and 1997 WL 446239 (N.D. Cal. 1997)

2591996 WL 197671 (N.D. Ill. 1996) and 1996400017 (N.D. Ill. 1996) In addition, there were numerous purchasers of citric acid and lysine in each case which elected to be excluded from the class and commence their own non-class action cases. These opt-out cases settled as well.

260 The fructose defendants were Error! Main Document Only.Archer Daniels Midland Company (ADM), A.E. Staley Manufacturing Company, Cargill, Inc., and American MaizeProducts Company. 
As a result, the Fructose case became a heavily litigated case which lasted almost 10 years from inception to conclusion.

During the course of the Fructose Antitrust Litigation, there were three separate significant appeals to the seventh Circuit Court of Appeals:

1. In 216 F. 3d 621 (7th Cir. 2000), the court of Appeals was asked to rule on whether plaintiffs could enforce a subpoena to obtain copies of both audio and video recordings which were made by a Vice-President of Archer Daniels Midland during the course of the criminal price fixing investigation. These recordings had not been used in the criminal proceedings but were filed with the Department of Justice. The district court held that recordings of face-to-face-conversations should be produced but that audio recordings did not have to be produced. On appeal, the Court of Appeal required production of all the recordings filed with the Department of Justice.

2. In 295 F. 3d 651 (7th Cir. 2002), plaintiffs appealed the grant of a summary judgment by the district court against plaintiffs and in favor of all non-settling defendants. At the time this ruling was entered, there was only a single \$7 million settlement, so plaintiffs counsel were at risk for virtually all of their time and expense in the matter. On appeal, the Seventh Circuit reversed. After 
analyzing the record evidence, the court held that fact questions precluded the entry of summary judgment in favor of the defendants. In a subsidiary ruling, the court held that an adverse inference could be drawn against Archer Daniels Midland, but no other defendant, as a result of the refusal of two ADM officers to answer deposition questions on the grounds that their answers might tend to incriminate them. In rendering its' ruling, the Court of Appeals made two significant rulings relating to antitrust enforcement - - it declined to accept defendants' extreme interpretation of the application of the Matsushita case to the case on appeal and rejected defendants argument that if no single item of evidence presented by the plaintiff points unequivocally to conspiracy, the evidence as a whole cannot defeat summary judgment.

3. In 361 F. 3d 439 (7th cir. 2004), the Seventh Circuit was presented with the novel question of whether the trial court had the authority to effect severance of two defendants for trial by impaneling two separate juries to sit simultaneously in one trial. The trial court had ruled that it had such authority and that, therefore, severance into two separate trials was not necessary. On appeal, the seventh Circuit affirmed this ruling. 
As a result of their determined efforts, class plaintiffs and their counsel overcame the absence of a government indictment, ten years of litigation, and the entry of summary judgment for the defendants, and achieved a settlement of $\$ 531$ million, which resulted in payments of more than \$10 million to some absent class members. Without this private class action litigation, the purchasers of fructose during the class period would have received nothing, since there was not a single fructose purchaser which elected to be excluded from the class in order to pursue it's own case.

The judge who oversaw the case, the Honorable Michael M Mihm, repeatedly praised the effort and conduct of class counsel. "I've said many times during this litigation that you and the attorneys who represented the defendants here are as good as it gets. Very professional...You've always been cutting to the chase and not wasting my time or each others' time or adding to the cost of the litigation. And this was very difficult litigation... Skill and efficiency of the attorneys. As good as it gets. Complexity and duration of the litigation. It was very complex. We made some new law on more than one occasion... ${ }^{261} \mathrm{He}$ accordingly awarded class counsel costs plus $25 \%$ of the settlement fund.

261 See Trial Transcript of Oct. 4, 2004, at 45-46. 
In Re: Graphite Electrodes Antitrust Litigation, 2003 WL 22358491 (E.D. Pa. 2003)

This settlement in the last of three related cases is noteworthy because (1) the two defendants in this settlement returned over $\$ 47$ million to overcharged direct purchasers; (2) this cash recovery came from foreign firms; (3) legal fees were at most $15 \%$ of the total recovery; (4) the recovery was estimated at 105\% of their actual damages; (5) The cases were successful follow-ons to a federal criminal prosecution that resulted in a criminal fines of more than \$300 million against at total of six defendants.

This case is a "follow on case" to a federal criminal prosecution of an international price-fixing conspiracy. The plaintiffs were direct purchasers of the defendants products, graphite electrodes, in the U.S. market. (The steel industry uses graphite electrodes to general the intense heat needed to melt scrap metal and refine steel in electric arc furnaces.) The Department of Justice obtained over $\$ 300$ million in 
criminal fines against the cartel members and many of their executives. ${ }^{262}$

The Graphite Electrodes Antitrust Litigation consisted of three class action lawsuits alleging horizontal price-fixing in the graphite electrodes industry. ${ }^{263}$

During the period from December 1998 through November 2002, settlements were approved with all of the defendants

262 Kylie Cooper \& Adrienne C. Dedjinou, Twentieth Survey of White Collar Crime: Article: Antitrust Violations, $42 \mathrm{Am}$. Crim. L. Rev. 179, 214 (2005). The criminal fines for each company were: Mitsubishi of Japan, \$134 million; "SGL Carbon AG of Wiesbaden, Germany, \$ 135 million; UCAR international of Danbury, Conn., \$ 110 million; Showa Denko of Ridgeville, S.C., \$32.5 million; Tokai Carbon Co. of Japan, \$ 6 million; and Nippon Carbon, also of Japan, $\$ 2.5$ million. A seventh producer, the Carbide Graphite Group of Pittsburgh, cooperated in the investigation and the company and its executives received amnesty." J. Seper, Mitsubishi Fined for Price Fixing on Key Parts in Steel Industry, Wash. Times, May 12, 2001.

263 (1) Kentucky Electric Steel Inc. V. The Carbide/Graphite Group, Inc., SGL Carbon AG, and UCAR International Inc., No. 97-CV-4182 (E.D. Pa.), (2) Kentucky Electric Steel Inc. V. Showa Denko Carbon, Inc., No. 98-CV-1017 (E.D.Pa.), (3) Kentucky Electric Steel Inc., No. 99-CV-482 (E.D. Pa.). The defendants were: Tokai Carbon Company, Ltd., Tokai Carbon U.S.A., Inc. (collectively "Tokai"); SEC Corporation ("SEC") ; Nippon; Mitsubishi; VAW Aluminum AG, VAW Carbon GmBH (collectively "VAW"); The Carbide/Graphite Group, Inc. ("CG"); SGL Carbon AG, SGL Carbon Corporation (collectively "SGL") ; UCAR International Inc. ("UCAR"); and Showa Denko Carbon, Inc. ( "SDC").

One of the defendants, SGL, attempted to evade civil liability by filing for a Chapter 11 bankruptcy petition in 1998. The Third Circuit, however, ordered the dismissal of SGL's bankruptcy petition on grounds that it had been filed in bad faith. In re SGL Carbon Corporation, 200 F.3d 154 (3d Cir. 1999). 
except Mitsubishi and Nippon. The certified the class in the action against these two defendants in February 2003. Shortly thereafter, the plaintiffs reached a settlement with the remaining defendants, and the Court approved a notice of the proposed settlement on May 14, 2003. ${ }^{264}$

Under the terms of the proposed settlement, Mitsubishi agreed to pay the Class $\$ 45,000,000$, and Nippon agreed to pay $\$ 2,875,000$. Plaintiff's counsel agreed that their request for attorney fees would not exceed fifteen percent of the settlement funds, plus reimbursement of litigation costs and expenses. According to the notice of the proposed settlement, a pro rata distribution of the proceeds would be determined by using the overcharge percentage found in the report prepared by the Plaintiffs' expert on damages. ${ }^{265}$ The overcharge varied overtime and was higher for deliveries in the United states than for deliveries outside the United States. To account for the variance over time, the proposed settlement divided the relevant period of time into twelve six month periods and

264 See, Notice of Proposed Settlements with Mitsubishi Corporation and Mitsubishi International Corporation in the Amount of $\$ 45,000,000$, and With Nippon Carbon Company, Ltd. in the Amount of $\$ 2,875,000$, Class Action Determination and Other Matters, IN RE: Graphite Electrodes Antitrust Litigation, MDL No. 1244 (E.D. Pa. May 14, 2003).

265 The court does not appear to have made any published remarks regarding the quality of the work performed by the plaintiffs' attorneys. 
called for the assignment of an overcharge percentage for each period. ${ }^{266}$ Overall, the plaintiffs' expert estimated the amount distributed to the class members at $105 \%$ of their actual damages. ${ }^{267}$

Ellwood Quality steel had chosen to opt-out of earlier settlements and had succeeded in recovering larger amounts from the other defendants. As a result, the allocation plan in the proposed settlement with Mitsubishi and Nippon would have denied Ellwood any distribution of funds because its settlements outside the class exceeded the amount it would have otherwise received in the settlement with Mitsubishi and Nippon. Nonetheless, Ellwood chose to opt-in to the Mitsubishi/Nippon settlement, and it objected to the allocation plan insofar as it took into account Ellwood's prior settlements.

Judge Weiner denied Ellwood's objection. First, the provision ensured that all of the class members received equal distributions from the Mitsubishi/Nippon settlement. Second, there was precedent for offsetting a share of a class settlement with funds received in private litigation. Finally,

266 Although the class was limited to consumers who purchased graphite electrodes from July 1, 1992, through June 30, 1997, the proposed settlement provided for damages for purchases from July 1, 1992, to June 30, 1998. Id. at 3.

267 In re Graphite Electrodes Antitrust Litigation, 2003 WL 22358491, at *2 (E.D. Pa. 2003) 
Ellwood had received an opportunity to opt-out of the Mitsubishi/Nippon settlement and knowingly chose not to do so. The award of damages had a material effect on the earnings of at least some consumers. Roanoke Steel Corporation reported that $\$ 1.4$ million of its $\$ 1.5$ million profit for the first quarter of 2004 was attributable to the settlement. ${ }^{268}$

268 Roanoke Electric Steel Corporation Reports First Quarter Results, P.R. Newswire, March 9, 2004. 
IBM V. Microsoft

This case is noteworthy because: 1) It settled for $\$ 775$ million cash and a \$75 million credit toward Microsoft software; 2) It was a successful follow-on resolving claims between International Business Machines, Inc. ("IBM") and Microsoft arising from the U.S. government's antitrust case against Microsoft; 3) IBM's allegations were broader than those in the government's case; 4) The settlement was reached in the absence of a separate lawsuit; and 5) The federal judge in the government case found that Microsoft's anticompetitive practices harmed both competitors and consumers.

In November 2003, on the heels of a settlement with the Department of Justice, Microsoft entered into a tolling agreement with IBM extending the statute of limitations on antitrust claims to avoid protracted litigation and explore settlement options. ${ }^{269}$ The final settlement resolved claims arising from the government's case against Microsoft which was filed in 1998 and alleged violation of Sections 1 and 2 of the Sherman Act, including unlawful maintenance of monopoly power and unreasonable restraint on trade through anticompetitive

269 IBM, Microsoft and IBM Resolve Antitrust Issues, http://www-03.ibm.com/press/us/en/pressrelease/7767.wss (July $1,2005)$. 
marketing practices. ${ }^{270}$ The U.S. District Court for the District of Colombia issued findings of fact in the government case in November 1999 establishing that Microsoft had used its "prodigious market power and immense profits" 271 to harm competitors, including IBM. ${ }^{272}$ Specifically, the judge found that Microsoft had "punished" IBM for failing to halt the promotion of its own products that competed with Windows and Office by withholding technical and marketing assistance, blocking the issuance of a Windows 95 license, and forcing IBM

270 U.S. V. Microsoft Corp., 84 F. Supp. 2 d 9 (D.D.C. 1999). Although twenty states joined in the government action, nine ultimately joined in the final judgment while the remainder went on to pursue a full remedies trial. The final judgment which was entered on November 12, 2001, prohibited Microsoft from engaging in a number of anticompetitive practices, including discriminatory pricing and overcharging, and from retaliating against its competitors for supporting or developing certain competing software - the same actions the court identified as having harmed IBM. Final Judgment (Nov. 12 , 2001) (available at http://www.usdoj.gov/atr/cases/f200400/200457.htm) .

271 U.S. V. Microsoft Corp., 84 F. Supp. 2 d at 112.

272 Microsoft defended its actions in the press and complained that its competitors were using the government action out of jealousy to attack the company. The Microsoft-funded Independent Institute ran a full-page ad in both The Washington Post and The New York Times on June 2, 1999 delivering "An Open Letter to President Clinton from 240 Economists on Antitrust Protectionism." The letter complained that not only did consumers not ask for the antitrust actions, but that consumers benefited from Microsoft's success. An Open Letter to President Clinton from 240 Economists on Antitrust Protectionism (available at http://www. independent.org/pdf/open_letters/antitrust.pdf) . 
to pay higher prices. ${ }^{273}$ According to the findings, these actions also resulted in harm to consumers since, "some innovations that would truly benefit consumers never occur[ed] for the sole reason that they do not coincide with Microsoft's self-interest." ${ }^{274}$

Two months before the tolling agreement was set to expire, Microsoft and IBM entered into settlement discussions to resolve the claims arising out of the factual findings in the government case. The parties reached an agreement on July 1, 2005 whereby Microsoft agreed to pay \$775 million lump sum and extend a \$75 million credit toward Microsoft software. ${ }^{275}$ The settlement agreement resolved claims arising out of the government case, including the discriminatory pricing and

273 U.S. V. Microsoft Corp., 84 F. Supp. 2 d at 39.

274 Id. at 112 .

275 IBM, Microsoft and IBM Resolve Antitrust Issues, http://www-03.ibm.com/press/us/en/pressrelease/7767.wss (July $1,2005)$.

Although it is unclear whether IBM has used the \$75 million credit, a principal analyst commented that the company would "most likely procure Microsoft PC software, such as operating systems and office productivity applications, with that credit." Juan Carlos Perez, Microsoft to Pay IBM \$775 Million in Cash, Plus \$75 Million in Credit, InfoWorld (July 1, 2005) (available at http://www. infoworld.com/archives/emailPrint.jsp?R=printThis\&A =/article/05/07/01/HNmsibmsettle_1.html). 
overcharge claims addressed in the findings. ${ }^{276}$ The parties also negotiated to resolve claims related to IBM's OS/2 operating system and Smartsuite products. The OS/2 claims first arose in the early 1980s when the parties publicly agreed to develop the OS/2 operating system together as a replacement for MS-DOS, which was the original IBM operating system. ${ }^{277}$ Microsoft undercut that agreement when it developed its Windows operating system and also impacted the software that IBM and others initially developed for the os/2 system. ${ }^{278}$ The agreement does not include claims against Microsoft for harm to IBM's server hardware and software businesses, though IBM did agree not to assert claims for money damages for a period of two years and not to seek recovery for claims involving events prior to June 30, 2002. This exclusion leaves IBM the option to pursue further legal actions, particularly in Europe where antitrust disputes against Microsoft remain unresolved. ${ }^{279}$ The parties did not release any further details of the agreement. ${ }^{280}$

276 IBM, Microsoft and IBM Resolve Antitrust Issues, http://www-03.ibm.com/press/us/en/pressrelease/7767.wss (July $1,2005)$.

277 Markoff, N.Y. Times.

278 Id.

279 In 2004 the European Commission fined Microsoft $\$ 662$ million upon its determination that "the software maker had 
abused its dominance in desktop operating systems to gain an unfair advantage in related markets, including servers." Perez, InfoWorld. If this ruling is upheld on appeal, it could pave the way for a similar action by IBM.

280 Microsoft has paid more than $\$ 4$ billion to settle state and federal antitrust suits related to the government case, including those brought by Sun Microsystems, Gateway Computers and Novell, and 13 class actions. Perez, InfoWorld; see also Steve Lohr, Preaching from the Ballmer Pulpit, N.Y. Times (Jan. 28, 2007). Microsoft agreed to pay Gateway \$150 million over four years to settle its claims arising out of the government case, which were similar to IBM's discriminatory pricing and overcharge claims. Robert A. Guth, Microsoft Takes \$714 Million Charge, Wall st. J. A.2 (Apr. 12, 2005). In addition, "Novell settled antitrust claims related to its NetWare network operating system in November 2004, with Microsoft paying the company \$536 million." Perez, InfoWorld. 
In Re: Insurance Antitrust Litigation, 723 F. Supp. 464 (N.D. CA 19989); reversed, 938 F. 2d 919 (9th Cir. 1991); affirmed sub nom Hartford Ins. Co. v. California, 509 U.S. 764 (1993).

This highly publicized and jurisprudentially important case is notable because: 1 . It resulted in a settlement with significant prophylactic relief through an injunction that restructured the industry-wide mechanism for providing support and advisory services to Commercial General Liability insurance; 2 . It also included a total of $\$ 36$ million in cash paid by the defendants; 3 . Of the cash payout, $27.2 \%$ consisted of attorneys fees; 4. The cash component of the settlement was a creative remedy that: (i) funded the development of a Public Entity that provides risk management education and technical services to small businesses, public entities, and non profits; and (ii) funded the states for development of a risk database for municipalities and local governments. 5. Money was returned to American businesses from foreign (\$6 million) and domestic (\$30 million) reinsurers. 6. The private action was a follow-up to investigations initiated by state enforcers.7. The case went to the supreme Court and established important legal principles.

In 1989 the plaintiffs - consisting of "nineteen states and numerous private plaintiffs" 281 - sued "a group of insurance companies, reinsurance companies, underwriters, brokers and individuals, and the Insurance Services office,

281 In Re: Insurance Antitrust Litigation, 723 F. Supp. 464, 468 (N.D. CA 19989). 
Inc. ("ISO")"282 for alleged violations of Section 1 of the Sherman Act and state antitrust laws.

The insurance companies sold Commercial General Liability Insurance ("CGL"), which protects the insured against the risk of liability to third parties for bodily injury or property damages. To share their risks, insurers turn to reinsurers. "Reinsurance is arranged by specialized brokers and underwriters. Much ... [of which] is done by syndicates doing business through Lloyd's of London."283 The terms and availability of reinsurance directly affect those of primary insurance. The insurance association, ISO, had an important role in the furtherance of the business of insurance by the states, and consisted of 1400 domestic property and casualty insurers. ISO's function at that time was to draft the standard CGL forms that were submitted to state regulators for approval, and to provide support services by collecting statistical data and estimating risks relevant to the forms. This information was then used by the insurers in underwriting decision making, including pricing of premiums.

But the defendants' primary insurers didn't like the standard ISO form for CGL insurance, and challenged the accidental pollution and the "long tail"284 coverage. They "exerted concerted pressure on ISO to get it to withdraw its

282 Id.

283 In Re: Insurance Antitrust Litigation, 938 F.2d 919, 923 (9th Cir. 1991).

284 "Long tail" coverage means that a claim can be made after the policy has expired if the event occurred during the life of the policy. The defendants preferred a "claims made" form under which only claims made during the life of the policy would be covered. See Id. at 923 
form for CGL insurance." ${ }^{285}$ They also persuaded key foreign underwriters and substantial American reinsurers to join their boycott of the ISO form. "As a result of the reinsurers" actions, primary insurers were precluded from selling long tail insurance and also from selling accidental pollution insurance."286 Therefore the availability of these varieties of insurance was substantially diminished. Eventually, Iso gave into the pressure and eliminated the challenged accidental pollution coverage, and withdrew its support services for the challenged long tail insurance.

Plaintiffs subsequently filed this Complaint over an agreement between the domestic insurers and ISO to limit longtail risks, and the enlistment of the London reinsurance market to refuse to provide reinsurance for long-tail risks which competitors of the domestic insurers might wish to offer. This allegedly constituted a conspiracy to withhold the inputs required by competitors in order to be able to offer long-tail coverage in competition with the domestic defendants' short-tailed products. Plaintiffs also alleged that defendants' boycott removed their conduct from the insurance exemption to the antitrust laws, pursuant to section 3 (b) of the McCarran-Ferguson Act. The District Court dismissed the complaints on defendants' 12 (b) (6) motion. The court of Appeals for the Ninth Circuit reversed, and the Supreme Court granted certiorari. The Supreme Court affirmed the Court of Appeals and remanded for further proceedings. After the document discovery in the District Court had started, the case was settled.

285 Id.

286 Id. at 923, 924 
The settlement agreement of March 19, 1995287, consisted of significant injunctive relief and a cash payment of $\$ 36$ million. The underwriters from the London Market paid, as alleged co-conspirators, a part of this. The injunctive relief disengaged ISO from industry members and instead put them under control of an independent board of directors. Furthermore, certain defendants were restricted from participating in contract development activities for five years. A total of $\$ 9.8$ million dollars of the settlement fund was awarded for attorneys' fees, costs, and expenses for the private plaintiffs. The remaining $\$ 26.2$ million was placed in an escrow fund, of which $\$ 21$ million was used to develop the Public Entity Risk Institute ("PERI"). PERI provides risk management education and technical services to public entities, small businesses, and non-profit organizations. PERI seems to have become an extremely successful self-sustaining entity which, apparently, public risk managers find quite useful. Another $\$ 5.2$ million was distributed to the states for development of a risk database for municipalities and local governments.

287 http://www .abanet.org/antitrust/committees/stateantitrust/insurance.pdf 
In re Linerboard Antitrust Litig., MDL No. 1261, 2000 WL 1475559, at *1-3 (E.D.Pa. Oct.4, 2000) ("Linerboard I" ); In re Linerboard Antitrust Litig., 203 F.R.D. 197, 201-04

(E.D.Pa.2001) ("Linerboard II"); In re Linerboard Antitrust Litig., 305 F.3d 145, 147-49 (3d Cir.2002) ("Linerboard III"); In re Linerboard Antitrust Litig., 321 F.Supp 2d 619 (E.D. Pa. $2004)$.

Summary: This case is a good example of the significance of private enforcement because: 1. it was a class action that led to a cash settlement of $\$ 202.5$ million; 2 . the total settlement represented $42-55$ percent $^{288}$ of alleged damages; 3 . the awarded attorneys fees were $30 \%$ of the total settlement; 4. the court stated repeatedly that "the lawyering in the case at every stage was superb" $i^{289} 5$. "there was no prior government action to establish liability" ${ }^{290}$ and the plaintiffs "did not benefit from the fruits of a prior government investigation or prosecution."291

In 1998, the Federal Trade Commission (FTC) filed a complaint against stone Container Corporation (Stone) charging them "with a unilateral violation of section 5 of the Federal Trade Commission Act. According to the FTC, stone had attempted to reduce linerboard ${ }^{292}$ inventories and had "invite[d]" some of its competitors to join in a "coordinated

288321 F.Supp.2d 619 (E.D.Pa. 2004), at 623

2892004 WL 1221350, at *6 (E.D. Pa. June 2, 2004)

290 Id. at 5 .

291 Id. at 11

292 "Linerboard includes any grade of paperboard suitable for use in the production of corrugated sheets, which are in turn used in the manufacture of corrugated boxes (...) corrugated sheets are also referred to as containerboard." See 203 FRD 197 , at 201 
price increase." The FTC did not allege that any other manufacturer had accepted stone's "invitation," nor did it allege the existence of any conspiracy."293

Shortly after the complaint of the FTC, several lawsuits where filed against stone on behalf of corrugated sheets purchasers and others on behalf of corrugated box purchasers. The latter expanded their allegations in comparison to the complaint of the FTC. They not only charged stone, but also several of its competitors (manufacturers of linerboard), claiming that "the Non-Stone defendants accepted Stone's "invitation" to restrict the production of linerboard and artificially raise prices, resulting in an antitrust conspiracy in violation of the Sherman Act."294

In 2001 the corrugated sheets plaintiffs and the corrugated box plaintiffs joined and requested the court to certify both classes in re Linerboard Antitrust Litigation. "This case is grounded on allegations that defendants conspired to restrict the output of linerboard in order to support increases in the price of linerboard with the objective of increasing the price of corrugated sheets and corrugated boxes. Linerboard is the key component in production cost of corrugated sheets and corrugated boxes, and is the primary determinant of the prices of those items."295 The plaintiffs accused the defendants of a price fixing conspiracy in violation of the sherman act, based on an agreement between stone and the other defendants. The defendants agreed to "close their their mills for "market

293 Id., referring to: In re Linerboard Antitrust Litigation, 2000 WL 1475559, *1 (E.D.Pa, Oct. 4, 2000)

294 Id. at 202

295 Id. at 203 
downtime," thereby reducing industry inventory at mills and box plants. (...) stone would than purchase inventory from other manufactures while idling its own mills. (...) A total of 435,000 tons had been withdrawn from the market. Inventory reached "a twenty-year low in terms of weeks of supply" (...) [Defendants] successfully increased their prices for containerboard and boxes for the first time in more than two years." 296

The court ruled that the plaintiffs had sufficiently proven that the prices of corrugated sheets and boxes directly related to the price of linerboard. ${ }^{297}$ Therefore the court acknowledged that both classes of plaintiffs where direct purchasers of linerboard. On september 4, 2001 the court certified both classes of the plaintiffs.

Eventually four settlements were reached between the plaintiffs and the defendant. On April 21, 2004 the Court approved all of these settlements ${ }^{298}$, worth a total of $\$ 202,572,489$ which covers 55\% of the total damages for the limitations period and approximately $42 \%$ of the damages for the full period. ${ }^{299}$ The awarded attorneys' fees amounted $\$ 60,771,747$, representing $30 \%$ of the settlement, the amount requested. ${ }^{300}$

Furthermore the Court awarded $\$ 1,391,203$ in expenses and $\$ 25,000$ in incentive fees to each of the five corporate class representatives. The Court reasoned that "[a]s well as being

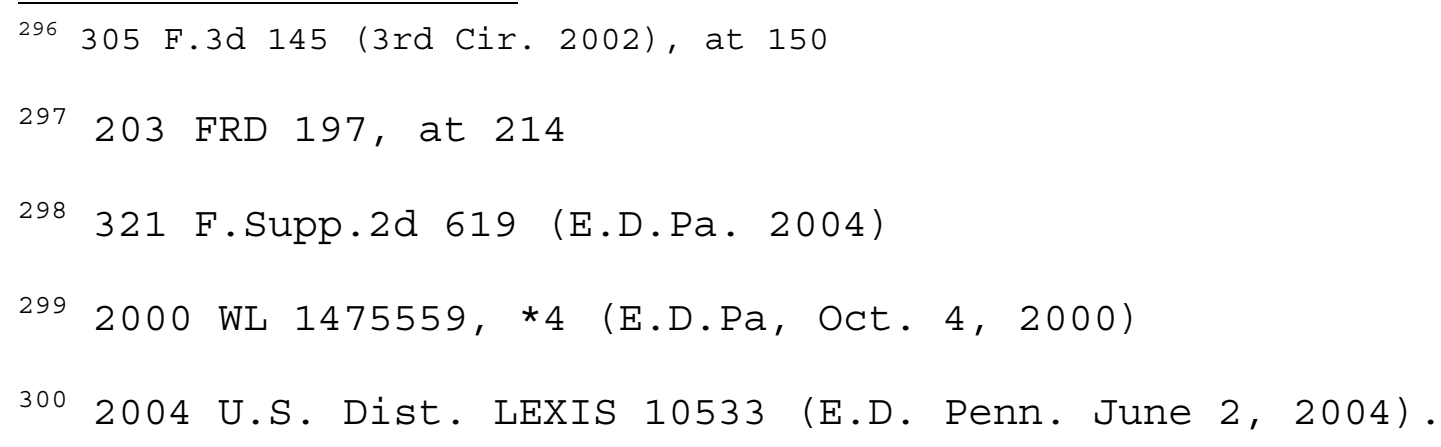


novel, this litigation was highly complex and thus required a great deal of lawyering skill."301 And "[t]he settlements are remarkable given the fact that there was no prior government action to establish liability and the case covered a relatively short conspiracy period of 26 months. The number of persons benefited is large, and includes all entities that purchased corrugated containers and sheets during the class period. (...) The size of that population is (...) approximately 80,000 companies."302 And finally, "[t]hroughout every phase of the litigation petitioners managed a major discovery effort" 303 and the plaintiffs "did not benefit from the fruits of a prior government investigation or prosecution." ${ }^{304}$

\footnotetext{
301 Id. at 14

302 Id. at *5

303 Id. at 10

304 Id. at 11
} 
In re Amino Acid Lysine Antitrust Litigation, MDL No. 1083, 918 F. Supp. 1190 .

This is a noteworthy price fixing settlement because: 1 . it led to a court approved cash settlement with the three major defendants of $\$ 45$ million and a the cash settlement with the other two defendants amounted almost \$5 million; 2. in addition, an estimated amount of \$15 million in cash was recovered by 33 plaintiffs who opted-out of the class settlement; 3 . in total about 400 direct buyers were recovered from their damage; 4. approximately \$24 million dollar of the total recovery to U.S. businesses was contributed by foreign companies; 5. only 7\% (\$3.5 million) of the total class settlement was awarded for counsel fees; 6. the main settlement was reached at a time that the government investigation of the same businesses appeared to be stalled and four months before the government obtained the first of its guilty pleas.

On June 27, 1995, the FBI raided the world headquarters of Archer-Daniels-Midland Company (ADM) in Decatur, Illinois; soon followed by raids on the offices of two Japanese companies: Ajinomoto and Kyowa Hakko Kogyo, and of two South Korean companies: Sewon and Cheil Jedang. All of the five companies manufactured or imported lysine and where suspected by the Department of Justice (DOJ) of price fixing agreements, a per se violation of the Sherman Act. "In september and November 1995, while the DOJ's investigation was continuing and formal federal charges had not yet been filed, a number of private civil (treble damages) suits were filed by buyers of 
lysine."305 The civil suits were brought together in one case, called Amino Acid Lysine Antitrust Litigation.

Lysine is an essential amino acid and a building block of proteins. It speeds the development of muscle tisssue and it is therefore an important supplement in animal feeds. Lysine is mainly produced by biotechnology. Since the late 1980s there were three major producers of lysine in the world: Ajinomoto and Kyowa Hakko of Japan, and Sewon of South Korea. Until 1991, the year in which ADM opened a new and very large lysine production facility in Decatur. This facility doubled the world's production capacity for lysine and brought ADM among the major producers. Cheaper production costs as well as the huge increase in supply, caused a steep decline in the prices of lysine of $45 \%$ in the first 18 months of operation. In 1992, ADM officials (including Mark Whitacre) met with officials of Ajinomoto and Kyowas Hakko and agreed to the formation of the International Amino Acids Manufacturers' Association. The meetings of the association became a forum for discussions of prices, production levels, and sales share allocations. Sewon and another South Korean company also joined the association. This resulted in rising prices of lysine. By the end of 1992, Mark Whitacre of ADM became an inside source of information for the FBI and he supplied them with evidence of the illegal meetings. The lysine cartel came to an end in June 1995, when the DOJ convened a grand jury in Chicago to consider the collected evidence of the price fixing conspiracy and the FBI raided the offices of the manufacturers. The DOJ investigation resulted in three major federal antitrust actions and lead to more than 40 civil

305 Lawrence J. White, Lysine and Price Fixing: How Long? How Severe?, Review of Industrial Organization, 18(1), Feb 2001, $23-31$, at 25 
antitrust suits in federal district courts by direct buyers of lysine.

The civil suits were brought together in 1996 under the name of Amino Acid Lysine Antitrust Litigation, in which about 400 plaintiffs were certified as a single class. This lead to a settlement offer by the three largest defendants in April 1996, totalling \$45 million. ADM offered $\$ 25$ million to the plaintiffs; Ajinomoto and Kyowa both offered \$10 million to settle the suit. "This offer came at a time when the DOJ's criminal investigation appeared stalled. Indeed, a rather unusual feature of the civil suit is that the settlement offer was made four months before the government obtained the first of its guilty pleas."306 Therefore the plaintiffs couldn't benefit from extensive information gathered from a closed grand-jury investigation or from facts admitted in guilty pleas. Subsequently, it was hard to determine the amount of overcharge, which resulted in a major dispute about the adequacy of the settlement amount.

"[A] number of plaintiffs objected that the proposed settlement was too low. A report by Connor (1996) supported these claims. (...) [H] e concluded that the combined priceovercharge and deadweight loss came to about \$165-\$180 million."307 However, "[c]rucial and controversial in Connor's analysis were his assumptions with regard to the "but for" price (...) and the time period during which the conspiracy had an effect on prices." ${ }^{308}$ In 2002 Connor adjusted his

306 John M. Connor (2002), Global Cartels Redux: The Amino Acid Lysine Antitrust Litigation (1996), at 17.

307 White, at 26 .

308 Id. at 27. 
earlier conclusions on the amount of the overcharge. He concluded that "[w] ith the benefit of hindsight and a great deal more information, it appears now that the first \$150million estimate by the plaintiffs was too high." ${ }^{309}$

In July 1996 the court determined "that the proposed payments in settlement by three of the defendants in this antitrust action (...) were within the range of fairness, adequacy and reasonableness." 310 About 33 plaintiffs chose to opt out of the settlement and according to estimates managed to settle for $\$ 15$ million. ${ }^{311}$ "Most of the opt outs were larger firms with the legal resources to continue hard negotiations with the defendants. Although settlement terms are confidential, reports in the press suggested that the opt-out firms, with the benefit of criminal guilty pleas by the lysine cartel members, got at least double the amount per dollar of purchases than did the smaller buyers in the class." 312

The two other lysine defendants settled with the plaintiffs for almost $\$ 5$ million in 1997. 313 "The federal lysine class and the opt-outs from the class eventually collected approximately $\$ 70$ million from the cartel members; indirect purchasers of lysine obtained an estimated \$15 million in state courts (...) Thus, U.S. lysine buyers

309 Connor (2002), at 28.

310 In re Amino Acid Lysine Antitrust Litigation, 1996 WL 411665 , at 1 .

311 Connor, John M. (1997) 'The Global Lysine Price-Fixing Conspiracy of 1992-1995', Review of Agricultural Economics, 19, 158-174, at table 1 .

312 Connor (2002), at 28.

313 Id. at 2 . 
recovered as a group slightly more than single damages; net of legal fees, buyers recovered less than single damages." 314 About $\$ 25$ million of the total recovery went from foreign violators of U.S. antitrust law to U.S. businesses. The court had awarded the role of lead class counsel on the basis of a fixed-fee auction. "The fee was capped at $\$ 3.5$ million for any settlements above $\$ 25$ million. The firm hired no economists to analyse the overcharge issue. The legal fees, at $7 \%$ of the settlement, were very low by historical standards." ${ }^{315}$ But it also lead to discussions whether the counsel represented the plaintiffs properly, namely "the suggestion, which has appeared in some of the media coverage, that the class counsel may have sold out too cheaply because of their unwillingness to invest all of the time that is required for the full representation of their clients' interests."316 But the court ruled that "it is a total red herring to suggest that either the bidding process to obtain the best quality representation at the lowest cost to the plaintiff class members, or the cap on fees that the Kohn firm chose to include in its ultimately successful bid, has in any respect disadvantaged the plaintiff class. Instead precisely the opposite is true." ${ }^{317}$

Apart from the treble-damage settlements, the DOJ obtained convictions for criminal price fixing by the five corporate lysine sellers. By the end of 1996 all the defendants had agreed to plea guilty to criminal price fixing

314 Id. at 29.

315 Id. Supra note 22, at 17.

316 In re Amino Acid Lysine Antitrust Litigation, 1996 WL 197671, at 1 .

317 Id. at 3 . 
charges. Ajinomoto and Kyowa paid a fine of \$10 million, Sewon paid a fine of $\$ 1.3$ million and ADM paid the largest fine of $\$ 70$ million. In addition, four of the executives who managed the conspiracy pleaded guilty and paid substantial fines. Four other executives were prosecuted by the DOJ. In 1999, three of them were found guilty and sentenced to long prison terms by a jury in Chicago. Michael D. Andreas, a top ADM officer, got sentenced to 36-month of imprisonment which is the maximum allowed by the Sherman Act. 
In re: Microcrystalline Cellulose Antitrust Litigation, MDL No 1402

These related cases are notable because 1) they produced recoveries for three classes of direct purchasers of Microcrystalline Cellulose ("MCC") against two defendants, the foreign Asahi Defendants and the domestic Defendant FMC Corporation; 2) Class Counsel recovered $\$ 25,000,000$ from each defendant for a combined total of $\$ 50,000,000$ plus accrued interest up to the date of payment; 3 ) this settlement amount represented approximately $40 \%$ of the damages claimed by the classes; 4) Plaintiffs' Counsel was awarded one-third (33 $1 / 3 \%$ ) of the combined gross settlement funds; 5) though this was a follow-on to an FTC action for violations of the Federal Trade Commission Act, Class Counsel alleged violations of Sections 1 and 2 of the Sherman Act and did further discovery to expose the defendants' involvement.

The background of this case was described by the United States District Court for the Eastern District of Pennsylvania, where the case was brought:

In the early 1960s, FMC purchased the company that had developed MCC and obtained a patent for the product. Shortly thereafter, FMC chose Asahi as the exclusive distributor of Avicel ${ }^{\circledR}$, its brand name of MCC, in Asia. FMC also licensed Asahi to manufacture some of its MCC products. The two companies continued to cooperate in marketing Avicel as well as some unbranded MCC products during the 1970s and 1980s. [This portion under seal]. From 1984 to 1997, the relevant class period, FMC sold approximately 50 different MCC products and blends for 
use in the pharmaceutical, vitamin, and food industries. The two major categories of MCC products are colloidal and non-colloidal. Non-colloidal MCC is used mainly in drug and vitamin tablets and some food products, while colloidal MCC is a blended product used in liquid drug suspensions and emulsions and other food products.

After FMC's patents expired, approximately ten firms entered the MCC market . . . . At least four of these competitors had exited the market by the early 1990s. By the late 1980s and early 1990s, FMC had lost some of its MCC market share to competitors that had expanded their MCC production, . . . Competition increased in the mid-1990s as competitors improved the quality of their MCC products and production neared market capacity. ${ }^{318}$

In late December of 2001, the FTC announced it had filed a complaint ${ }^{319}$ and simultaneously entered into consent decrees $^{320}$ with FMC and Asahi. The complaint alleged that FMC and Asahi had allocated geographic markets for MCC. The FTC also alleged that FMC solicited other MCC manufacturers to conspire to allocate markets. ${ }^{321}$ This complaint was brought under Section 5 of the Federal Trade Commission Act. ${ }^{322}$

318 In re: Microcrystalline Cellulose Antitrust Litigation, 218 F.R.D. 79, 82 (2003) (internal citations omitted); [hereinafter "MCC litigation"].

319 www.ftc.gov/os/2000/12/fmcasahicomplaint.htm; www.ftc.gov/opa/2000/12/fmc.htm.

320 www.ftc.gov/os/2000/12/fmcconsent.htm.

321 See 65 FR 83038 Federal Trade Commission Analysis to Aid Public Comment (Dec. 29, 2000); also see www. ftc.gov/opa/2000/12/fmc.htm.

32215 U.S.C. $\$ 45$. 
The FTC Consent Order prohibited Asahi and FMC from conspiring further, and barred FMC for a number of years from serving as the U.S. distributor for any MCC competitor including Asahi. ${ }^{323}$

As a result of these and a public announcement by the FTC, Class counsel investigated potential claims. The first complaint was filed in January 2001 by the Ivax Corporation, a firm that had purchased MCC products from FMC, against FMC and Asahi. The plaintiffs alleged that FMC and Asahi conspired to allocate the MCC market in violation of Sections one and Two of the Sherman Act. ${ }^{324}$

Classes were certified in August, 2003. ${ }^{325}$ There were three classes which consisted of approximately 1700 class

323 http://www.ftc.gov/os/2000/12/fmcd_o.pdf . 324 MCC litigation at 81, ("See Complaint in Civ. A. No. 01111 . . . In simple terms, the alleged agreement barred Asahi from selling any MCC products in North America or Europe without FMC's consent and barred FMC from selling MCC products in Asia. Plaintiffs claim that this alleged allocation of the market was an unreasonable restraint of trade in violation of Sections one and Two of the Sherman Act. See 15 U.S.C. §§ 1, 2. The action is brought under sections 4 and 16 of the Clayton Act, which provide for the private enforcement of the antitrust laws to recover resulting damages. See 15 U.S.C. $\S \S$ $15(a), 26 . ")$.

325 MCC litigation. 
members, the Pharmaceutical Class, the Vitamins Class, and the Food Purchasers Class. ${ }^{326}$

Though this private action was a follow on to the FTC action, Class Counsel argued that the FTC's case was not sufficiently developed to permit Class Counsel to rely on any record created by the FTC. Class Counsel fought discovery battles to retrieve documents that had not been uncovered by the FTC. The FTC did not take discovery of the Japanese Asahi entity responsible for manufacturing MCC, but only sought documents from the American affiliate, which related to jurisdictional issues. Class Counsel asserted that the

$\overline{326}$ MCC litigation at 94 :

In August of 2003, the Court determined that this case could proceed as a class action and certified the following three classes:

1. The Pharmaceutical Class is defined as: United States All persons or entities in the United States who purchased microcrystalline cellulose directly from defendant FMC Corporation in the United States for use in connection with the manufacture or preparation of prescription and/or over-the-counter pharmaceutical products at any time during the period January 1, 1984 through December 31,1997. The Class excludes governmental entities, defendants, defendants' parents, subsidiaries, and affiliates.

2. The Vitamins Class is defined as: [all direct U.S. purchasers of MCC] for use in connection with the manufacture or preparation of vitamin products [during the relevant time period].

3. The Food Purchasers Class is defined as: [all direct U.S. purchasers of MCC] for use as a food additive [during the relevant time period]. 
documents received from Asahi, along with depositions of Asahi employees, were essential to this case. ${ }^{327}$

In April 2005 Class Counsel was able to negotiate a settlement with Asahi. Asahi agreed to make a \$25 million dollar cash payment, and to cooperate with Plaintiffs litigation against FMC. ${ }^{328}$ Class counsel received approval from the court to use up to $\$ 2,500,000$ of the proceeds from that settlement to pay expenses in the FMC litigation. ${ }^{329}$ Class Counsel submitted merits expert declarations finding that the relevant antitrust market was the sale of MCC to pharmaceutical and vitamins manufacturers in the U.S., the entry of small, lower quality MCC manufacturers into the US market during the class period was insufficient to prevent FMC from exercising monopoly power. FMC Defendant's merits declaration of two experts found that Asahi's decision not to enter the U.S. market was consistent with independent business

327 In re: Microcrystalline Cellulose Antitrust Litigation, MDL No. 1402, Memorandum of Law in Support of Petition for Award of Attorney's Fees, Reimbursement of Expenses, and Incentive Payments to Class Representative, pages 9 - 11; [hereinafter "Memo in support of Fees"].

328 In re: Microcrystalline Cellulose Antitrust Litigation, MDL No. 1402, Declaration of $\mathrm{H}$. Laddie Montague, Jr. in Support of Plaintiff's Motion for Final Approval of the Settlement with Defendant FMC Corporation and for an Award of Attorney's Fees and Reimbursement of Expenses, page 2, I 5; [hereinafter "Montague Declaration"].

329 Memo in Support of Fees at 11. 
decision making. The experts based this on findings that Asahi was not successful in selling MCC outside of Japan, faced capacity and distributor network restraints, and did not have a plant in the U.S. ${ }^{330}$

Class Counsel reached a settlement with FMC while an FMC summary judgment motion was pending. ${ }^{331}$ The settlement with FMC consisted of a cash payment of $\$ 25,000,000$. This occurred after more than five and a half years of litigation, and the gross settlement fund represented approximately $40 \%$ of the damages claimed by all three classes over the 14 year class period. ${ }^{332}$ This settlement was approved by the Court. ${ }^{333}$

The Pharmaceutical/Vitamin Classes' Counsel used an expert, Dr. John C. Beyer, to calculate that the Pharmaceutical and Vitamin Classes suffered an average overcharge of $22.1 \%$ in purchases of MCC from FMC, which translates into class-wide single damages of $\$ 78.259$ million. The Food Purchasers Class Counsel used an expert, Dr. Douglas F. Greer, to calculate that the Food Purchaser Class suffered

330 Montague Declaration at 21,22 .

331 Id. at 29 .

332 Id. at 30 .

333 In re: Microcrystalline Cellulose Antitrust Litigation, MDL No. 1402, Final Judgment Order (Nov. 20, 2003); [hereinafter "Final Judgment Order"]. 
an average overcharge of $18.5 \%$, which translates into classwide single damages of $\$ 50.9$ million. ${ }^{334}$

These percentages served as the basis for a proposal by the Plaintiffs' Counsel as to each Class' allocation. Members of the Pharmaceutical/Vitamins Classes' claims were to be calculated at the rate of $22.1 \%$ of their purchases of MCC from FMC. ${ }^{335}$ These allocations were approved by the Court. ${ }^{336}$

334 In re: Microcrystalline Cellulose Antitrust Litigation, MDL No. 1402, Plaintiffs' Proposed Plan of Distribution (attached to Final Judgment Order as Exhibit C) page 2, 3 . 335 In re: Microcrystalline Cellulose Antitrust Litigation, MDL No. 1402, Agreement of Settlement and Plaintiffs' Proposed Plan of Distribution (attached to Final Judgment Order as exhibits $B$ and $C$ respectively).

336 Final Judgment Order at 2 . 
In Re: NASDAQ Market-Makers Antitrust Litigation, M.D.L. No, 1023, No. 94 Civ. 3996 (RWS) (S.D.N.Y. 1998).

Summary: The NASDAQ litigation is an outstanding example of private antitrust litigation because: 1 . the case returned a significant amount of cash to victimized consumers (\$1.027 billion plus interest); 2. It involved a large nationwide class action; 3 . It was not a follow-up to a government action (private attorneys uncovered the wrongdoings, initiated the litigation, and carried it to conclusion); 4. The awarded attorneys' fees were quite modest in percentage terms (only 13\% of the total recovery); and 5. It achieved important prophylactic relief.

In 1993 private plaintiffs began their investigation of possible collusion involving NASDAQ. ${ }^{337}$ It was triggered by a Forbes article 338 that criticized the influence of large market-makers trading on NASDAQ, and it was supported by a later study which concluded: "In effect, spreads on the affected NASDAQ securities were rounded-up to the nearest even-eight, and were therefore substantially larger than spreads on comparable securities traded on the NYSE." ${ }^{339}$

The private plaintiffs filed their complaints in May 1994, representing "a class of over 1.0 million individual and

337 See Arthur M. Kaplan, "Antitrust As A Public-Private Partnership: A Case Study of the NASDAQ Litigation", 52 Case W. Res. L. Rev. 111, 114 (2001). This summary is based upon Kaplan's article.

338 Gretchen Morgenson, "Fun and Games on NASDAQ", Forbes, Aug. 16, 1993, at 74 .

339 Kaplan, supra note 1, at 114. See William Christie \& Paul Schultz, "Why Do NASDAQ Market Makers Avoid Odd-Eighth Quotes?", 49 J. Fin. 1813, 1840 (1994). 
institutional investors who purchased or sold shares of class securities on the [NASDAQ Exchange] during the period of May 1, 1989 to May 24, 1994"340 The defendants consisted of thirtyseven market makers on the NASDAQ Exchange. ${ }^{341}$

One of plaintiffs' earliest actions was to obtain a document preservation order which prevented periodic erasure and recycling of crucial audiotapes. This happened long before any government subpoenas. It was not until after the class actions were filed that the SEC and the DOJ opened formal investigation in the fall of 1994. "Without the early preservation orders crucial evidence would have been lost to private plaintiffs and the government. The preserved audiotape eventually provided important, direct evidence of collusion." 342

The Defendants planned to file a motion arguing antitrust preemption, and contacted the SEC. But after the plaintiffs met with the SEC, the SEC decided that the complaint was not preempted. The plaintiffs initiated another meeting with the Antitrust Division of the DOJ and convinced them, by presenting factual and economic evidence, to start an investigation. As Professor John C. Coffee, Jr. (member of the Legal Advisory Board of the National Association of Securities Dealers ("NASD") stated in his affidavit: "[private plaintiffs] awake the federal government to ... price collusion

340184 F.R.D. 506 (S.D.N.Y. 1999).

341 A market maker quotes a buy and sell price, trading for its own account. Their profit - or for the party at the other side, the trading costs - derives from the spread between the bid and the offer. That is the difference between the buying and selling price of the same stock.

342 Kaplan, supra note 1 , at 117. 
that the government had previously ignored," and pulled "the principal laboring oar in advancing this case." 343

This early cooperation between the plaintiffs and the SEC resulted in a consent agreement with the NASD on August 8 , 1996, reorganizing the NASD and NASDAQ, followed by the implementation of new trading rules for NASDAQ. "The new rules (expressly formulated in response to imperfect competition on Nasdaq) furthered and systematized the narrowing of spreads that already had occurred on many high profile Nasdaq securities, under the glare of publicity and private litigation." ${ }^{344}$

The discovery leading to class certification was a complex process. The plaintiffs also actively helped to keep the government investigation alive by providing them with relevant factual and economic information. ${ }^{345}$ In the end the plaintiffs "reviewed and analyzed over 3,000,000 pages of documents, and over 10,000 hours of audiotape, in addition to the numerous depositions taken by plaintiffs, and more than 200 government transcripts."346

The plaintiffs achieved the first individual settlement on April 9, 1997. But it was difficult to reach a collective settlement with the defendants, who where resisting an all cash settlement in favor of a coupons settlement. On March 23, 1998 the last settlement was signed. "The settlements in the aggregate totaled approximately $\$ 1.027$ billion. [All cash!] An

343 Affidavit of John C. Coffee, Jr. par. 24, In re Nasdaq Market-Makers Antitrust Litigation, M.D.L. No. 1023, No. 94 Civ. 3996 (RWS) (S.D.N.Y. 1998).

344 See Kaplan, supra note 1, at 120 .

345 Id. at 119 .

346 Id. at 125 . 
affidavit of Professor Michael Barclay showed that this amount approximated plaintiffs' individual damages." 347 on top of this, the private litigation and the new SEC rules greatly reduced NASDAQ spreads. An subsequent study showed a "large decline" in NASDAQ spreads, resulting in newly "competitive pricing." ${ }^{348}$

Because the awarded attorneys' fees were quite modest in percentage terms (only 13\% of the total recovery), a total of $\$ 896,233,301$ were paid to class members. Approximately 1,249,500 claimants received payment, with a range from $\$ 25$ to more than $\$ 11$ million. ${ }^{349}$ The cooperation between the private plaintiffs and the government agencies resulted in the largest antitrust recovery in history at the time of the final settlement. And, as strikingly pointed out by Professor Stephen Calkins: "NASDAQ did not follow a prior governmental investigation. Indeed, the private action appears to have triggered the governmental activity." 350

347 Id. at 128 .

348 James P. Weston, "Competition on the Nasdaq and the Impact of Recent Market Reforms", 55 J. Fin. 2565, 2566 (2000). Kaplan at 128

349 Re Nasdaq Market-Makers Antitrust Litigation, 2000-1 Trade Cas. (CCH) at 86,648 (S.D.N.Y. 2000).

350 Stephen Calkins, An Enforcement Official's Reflections On Antitrust Class Actions, 39 Ariz. L. Rev. 413, 422 (1997). See also id. at 443 ("NASDAQ's genesis was entirely private.") 
Law v. National Collegiate Athletic Ass'n., 902 F.Supp. 1394 (D.Kan. 1995); affirmed, 134 F. 3d 1010 (10th Cir. 1998); reversed, 938 F. 2d 919 (9th Cir. 1991).

This case is an interesting example of recent antitrust litigation for six reasons: 1 . The National Collegiate Athletic Association holds a unique position in multiple markets, as both a major producer and consumer, based on the distinct relationship between higher education and sports marketing; 2. The trial court: (i) examined the case under a "quick look" rule of reason analysis, and (ii) made specific determinations that there was an antitrust violation; 3 . The anticompetitive action significantly depressed wages in the market for assistant college coaches; 4. The case included a total of $\$ 74.5$ million in cash paid by the defendants; 5 . Of this total, $\$ 20$ million (26.8\%) went for attorneys' fees and expenses; 6. The case was exclusively litigated by private parties, without any Federal or state action taken.

In 1989, the National Collegiate Athletic Ass'n. ("NCAA") formed the Cost Reduction Committee ("Committee") in response to rising costs in athletic programs. "As a result of its deliberations, the [c] ommittee proposed legislation (collectively, the "Restricted Earnings Coach Rule"),"351 which was subsequently adopted in January 1991 by Division I NCAA members. Essentially the rule limited the number of coaches allowed on each college team who were allowed to make more than a baseline level set by the REC rule.

In 1994, several coaches who had been adversely affected by the REC rule brought separate suits against the NCAA,

351 See Law V. National Collegiate Athletic Ass'n., 902 F. Supp. 1394, 1400-401 n. 5 (D.Kan. 1995). 
claiming injuries as a result of antitrust violations. Plaintiff's jointly brought a motion for summary judgment asserting that the "NCAA . . conspired to limit the compensation they will pay to one category of . . coaches [and] that the restriction on its face is an impermissible restraint of trade." 352

In response, the NCAA offered several arguments designed to show that the REC rule was justified, including: (1) The rule was "necessary to maintain competitive equity and to prevent schools from escalating personnel expenditures," 353 (2) "establish an "unrestricted" head or assistant coach category that will accommodate any type of volunteer, paid, full-time or part-time coach, and (3) establish a "restrictedearnings" category that will encourage the development of new coaches while more effectively limiting compensation to such coaches." ${ }^{354}$

The trial court began its analysis by explaining that although such an obvious case of horizontal price fixing among NCAA Division I institutions would normally be subject to a "per se" analysis, such application would be inappropriate under the Supreme Courts holding in NCAA V. Board of Regents of the Univ. of Oklahoma, 468 U.S. 85 (1984). ${ }^{355}$ Based on the unique situation of college sports, some horizontal collusion is necessary to preserve the integrity of the NCAA and its

\footnotetext{
352 Id. at 1398 .

353 Id. at 1399.

354 Id. at 1401.

355 Id. (explaining that the NCAA is "an industry in which horizontal restraints on competition are essential if the product is to be available at all").
} 
ability to make college sports available to the public. As such, the court analyzed the NCAA's actions under a "quick look" rule of reason standard. ${ }^{356}$

The trial court determined that the NCAA, through application of the REC rule, prohibited the operation of the free market by limiting demand for coaches, some of whom made "\$60,000 to $\$ 70,000 "$ before the implementation of the rule. ${ }^{357}$ The court was not persuaded by any of the NCAA's justifications for the REC rule, finding that they offered no evidence to support the conclusion that they were trying to promote competition; rather, that the NCAA's actions were solely in the interest of it's member institutions financial stability. As such, the trial court granted the plaintiff classes' motion for summary judgment on the issue of liability, finding that the NCAA failed to meet the burden of showing "that the Restricted Earnings Coach Rule actually promotes a legitimate, pro-competitive objective." 358

Subsequent to the court granting plaintiffs' motion, the plaintiff groups filed motions for permanent injunction, ${ }^{359}$ and a motion for class certification for proceedings on injunctive relief and damages. ${ }^{360}$ Although the court recognized that many

356 "[U] nder the quick look standard[,] because adverse effects on competition are apparent, the court does not require proof of market power, and instead moves directly to an analysis of the defendant's proffered competitive justifications for the restraint." Law v. NCAA at 1405 .

357 Id.

358 Id. at 1410; affirmed 134 F.3d 1010 (10th Cir. 1998).

359 Law V. NCAA, Not Reported in F.Supp., 1996 WL 104328

(D.Kan. 1996)

360 Schreiber V. NCAA, 167 F.R.D. 169 (D.Kan., 1996.) 
of the plaintiffs were no longer employed with NCAA Division I schools, so as to be immediately in danger of suffering irreparable harm, plaintiffs who could demonstrate harm would be entitled to an injunction prohibiting the NCAA from enacting similar legislation in the future. However, the court declined to certify the plaintiffs as a class with respect to damages, because they failed to show a manageable method of dealing with individual issues of harm.

On plaintiffs' request for interim attorneys fees pursuant to $\$ 16$ of the Clayton Act, 15 U.S.C. \$ 26, the court acknowledged that plaintiffs had substantially prevailed in the litigation, however there were complications as to the reasonable amount to be awarded each attorney. Although the court ordered the NCAA to pay out interim fees by April 29, 1996, the NCAA failed to do so and had sanctions imposed by the court accordingly. ${ }^{361}$ On appeal, the court upheld the order imposing the payment of interim fees, but reversed based on the trial courts failure to adequately notify the NCAA of the possibility of being held in criminal contempt.

After the Court of Appeals for the 10th Circuit affirmed the trial court's order granting plaintiff classes motion for summary judgment, ${ }^{362}$ the trial court considered the issue of damages with regards to individual plaintiffs and the class as a whole. In three separate class awards, class representatives Law, Hall and Schreiber were awarded CPI adjusted damages of $\$ 12,053,528.00, \$ 10,194,861.00$, and $\$ 1,704,059.00$ for their classes, respectively. ${ }^{363}$ After trebling of damages, the total

\footnotetext{
361 See Law V. NCAA, 134 F.3d 1025, (10th Cir. 1998).

362 Law V. NCAA, 134 F.3d 1010 (10th Cir. 1998).

363 Law V. NCAA, 185 F.R.D. 324 (D.Kan. 1999).
} 
amount of damages awarded to the classes was $\$ 71,857,344.00$, although the prior injunction against NCAA was reversed due to availability of appropriate remedies for future harm. ${ }^{364}$

What appeared to be an ending to five years of back and forth rulings and appeals was not quite over.

"Before the Court awarded attorneys' fees, the NCAA agreed to pay $\$ 54,500,000.00$ to settle the lawsuits. On August 31, 1999, the Court approved the settlement but did not rule on the allocation of the proceeds among class members. On August 31 and September 3, 1999, the Court awarded attorneys fees in the amount of $\$ 18,209,149.50$ and costs in the amount of $\$ 1,749,302.80$ to counsel for plaintiffs." 365

In 2000, the court set out the terms of a revised settlement allocation fund based on the trial testimony of plaintiffs' expert; which was upheld on appeal as a reasonable method for fair payment allocation. Finally, all of the excess damages from the settlement, after paying out the coaches and attorneys, were donated to various charitable organizations.

\footnotetext{
364 Id. at 350 .

365 Law V. NCAA, 108 F.Supp.2d 1193, 1195 (D.Kan. 2000).
} 
North Shore Hematology \& Oncology Associates V. Bristol-Myers Squibb Co., Civil Action No. 1:04CV248(EGS) (2004)(Platinol)

This case is notable because: 1. The plaintiffs obtained a $\$ 50,000,000$ verdict in a Section 2 case; 2. This case settled in less than one year after its inception as a followup to an FTC case. ${ }^{366}$

Bristol Myers Squibb (BMS) developed cisplatin, a drug used to treat certain types of cancer, under the brand names "Platinol" and "Platinol AQ" (Hereinafter collectively referred to as "Platinol"). ${ }^{367}$ Both drugs contain the same active ingredient, cisplatin. ${ }^{368}$ The Plaintiffs, direct

366 This case was filed on May 22, 2004. The Final order Approving Settlement was entered on November 30, 2004. Docket entries available at: https://courtlink.lexisnexis.com/ DocketSearch/Results.aspx. The Federal Trade Commission filed the government case on April 23, 2003. Complaint, In The Matter of Bristol-Myers Squibb Company, A Corporation, available at:

http://www.ftc.gov/os/2003/04/bristolmyerssquibbcmp.pdf. The government case ended in a Consent Order on March 7, 2003. According to FTC Chairman Timothy Muris, the consent order "stands for an important proposition: competition must be on the merits, not through misusing the government to stifle your competition." FTC Charges Bristol-Myers Squibb with Pattern of Abusing Government Processes to stifle Generic Drug Competition, available at: www.ftc.gov/opa/2003/03/bms.htm. However, the government suit did not reimburse direct purchasers for the overcharges they paid BMS as a result of the company's anticompetitive conduct.

367 Notice of settlement at 1 .

368 Id. The only significant difference between the two drugs is that Platinol $\mathrm{AQ}$ is the aqueous form of the drug and Platinol is a freeze-dried powder form. 
purchasers of Platinol, sued BMS for maintaining an illegal monopoly in the cisplatin market, by fraudulently obtaining patents and filing a series of "sham" patent infringement lawsuits. 369

Under the Hatch-Waxman Act, the FDA grants pharmaceutical companies a statutory monopoly when the company develops a new drug. During this exclusivity period, the drug manufacturer is free from generic competition. When the exclusivity period ends, generic manufacturers may apply to the FDA for approval to sell generic bioequivalents. ${ }^{370}$ During the generic approval process, if a name brand manufacturer files a patent infringement suit, it triggers an automatic thirty-month stay against generic entry into the market.

Direct purchasers of Platinol sued BMS on February 13, 2004 under Section 2 of the Sherman Act. ${ }^{371}$ They argued that BMS unlawfully maintained its monopoly by filing a series of

369 The market was defined as Platinol which was purchased from "Bristol Myers squibb Company or its wholly-owned subsidiary Oncology Therapeutic Network, Inc., any time from June 19, 1999 through September 8, 2004" in the United States. Id.

370 Generic bioequivalents offer consumers the same therapeutic value and active ingredients as their brand name counterparts, at a significantly lower cost. Id.

371 They accused BMS and its wholly-owned subsidiary, Oncology Therapeutic Network, Inc. of maintaining a monopoly from June 28, 1999 to september 8, 2004. Notice of Settlement at 1. 
frivolous patent infringement suits against would-be generic competitors. Due to the absence of generic competition, they claimed that they were forced to purchase Platinol from BMS at supracompetitive prices.

The putative anticompetitive conduct began in 1995, when several generic manufacturers applied for FDA approval of generic cisplatin. ${ }^{372}$ Less than two months before BMS' patents were set to expire, BMS applied for a new patent. ${ }^{373}$ BMS stated it had recently discovered Platinol had additional properties that were not included in the earlier patents. ${ }^{374}$ Specifically, the prior patents did not contain any "protected from light" language. ${ }^{375}$ The plaintiffs argued that it was common knowledge that Platinol and other Platinum-based compounds had to be protected from light. ${ }^{376}$ According to the

372 Complaint at $\mathbf{1} 111$, In Re Bristol Myers Squibb Co., Before Federal Trade Commission, available at: http: //www.ftc.gov/os/2003/03/bristolmyerscmp.pdf

373 Id. at 9115 .

374 Id. at I 113 .

375 Cisplatin is a platinum-based compound, which is sensitive from light. More importantly to the plaintiffs, the new patent would also prolong BMS' statutory monopoly in the cisplatin market for another thirty months.

376 According to the plaintiffs, the fact that Platinol had to be protected from light was common knowledge in the medical field for some time. In fact, they argued that it was known as far back as 1967, when this information was published in a widely-read medical journal. Id. at I 113. 
plaintiffs, BMS filed a series of "sham" infringement suits in order to prevent generic competition. ${ }^{377}$

This case settled less than one year after its inception, for $\$ 50$ million in cash. ${ }^{378}$ The Court awarded Plaintiffs' Counsel $33 \%$ of the settlement fund. ${ }^{379}$ The $33 \%$ award in this case has been cited as precedent in other complex antitrust cases involving pharmaceutical companies engaged in similar conduct. ${ }^{380}$

377 In the first year generic competitors entered the cisplatin market, Platinol sales decreased by fifty percent. Notice of settlement at 4. November 30, 2004 .

378 Id.

379 Id.

380 The judge in Remeron cited this case as precedent, noting that "the requested fee is consistent with awards in other complex antitrust actions involving the pharmaceutical industry". In re Remeron Direct Purchaser Antitrust Litig., 2005 U.S. Dist. LEXIS 27013, 27044. Id. 
In re Lease Oil Antitrust Litigation (No. II), 186 F.R.D. 403 (S.D. Tex. 1999), 142 Oil \& Gas Rep. 532 (1999)

This is a noteworthy example of private enforcement because: 1) it involved a nationwide class action; 2) the case brought a sizeable amount of cash to the class: $\$ 164.2$ million under the Global settlement, plus $\$ 29.3$ million in the Stand Alone settlements, a total of $\$ 193.5$ million; $^{381} 3$ ) the attorney fees were $25 \%$ of the total amount.

In 1996 a class action suit was filed against 39 oil companies in federal court on behalf of a putative nationwide class of royalty and working interest owners alleging that those companies, in violation of section 1 of the sherman Act, conspired for over a decade to artificially depress payments made for oil leases. ${ }^{382}$ These claims, asserted by the plaintiffs in the McMahon case, depended on proving that defendant oil producers and transporters entered a pricefixing conspiracy to depress posted prices, and thereby, depressed the market price for oil at the lease.

One year later, the lead plaintiffs in the class action suits presented a settlement agreement with 24 defendants. Before any ruling on that settlement, the Judicial Panel on Multidistrict Litigation transferred these suits to the District Court, S.D. Texas, for coordinated and consolidated proceedings as In re Lease Oil Antitrust Litigation. ${ }^{383}$

381 None of the recovery came from a foreign corporation. 382 MCMahon Found. V. Amerada Hess Corp., 98 Fed. Appx. 267 (5th Cir. 2004).

383186 F.R.D. 403, 408 (S.D Tex. 1999). Prior to the class action, there was significant litigation and discovery in several actions consolidated in this case. Mr. Godfrey 
The Court facilitated the division of the parties present into four groups: Settling Plaintiffs (including Godfrey and Kipple (the two lead plaintiffs in the class action suits [above]), and counsel for related settling cases), settling Defendants, Non-settling Plaintiffs and Non-settling Defendants. ${ }^{384}$ The settling Defendants and settling Plaintiffs presented testimony in support of their respective positions and in support of the Global settlement. In addition to the Global settlement, counsel for both the settling Plaintiffs and Non-settling Plaintiffs reached seven distinct settlement agreements with seven remaining Non-settling Defendants, which make up the Stand Alone settlements. ${ }^{385}$ Since these seven defendants represented all of the remaining significant defendants in the oil industry, the final approval, given by the Court, of these stand Alone settlements along with the

began investigating this litigation in 1993, and entered global settlement negotiations when on the brink of beginning a class certification hearing. Id. Actual notice of the eight settlements was attempted to all class members who had received payments from Defendants since 1986. In McMahon, the plaintiffs were forced to amend their initial complaint, and subsequently, they successfully defended their amended complaint from motions to dismiss by various defendants. MCMahon Found., 98 Fed. Appx. at 267-70. There were approximately five million documents in the MDL-1206 document depository, and it is estimated that there were several million more documents which counsel have made available for review. Id. at 408 .

384 Id. at 408 .

385 The Stand Alone Settlements adopt the basic structure of the Global settlement with limited exceptions, using the same definitions and releasing the same set of underpayment claims for the same class of royalty and working interest owners. The important difference between the Global and stand Alone Settlements is the consideration provided and the rate of recovery to certain class members for their royalty and/or working interest barrels. 
Global settlement meant the conclusion of the multidistrict litigation.

In order to understand the basis of the plaintiff's claims for damages, it is necessary to explain some background information about the oil industry - in particular, about the movement of crude oil from the well or "lease" to the trading centers. There are certain kinds of transactions that take place at the two transfer points: 1) at the lease, where oil is transferred from the well into a transportation system of some type, and 2) at the trading center. At the trading centers oil is sold at a price which unquestionably represents the actual market value of the oil at those trading centers. The market price at the trading center is certainly a reliable measure of market value because hundreds of thousands of barrels are purchased each day at these centers by numerous refiners which compete for these barrels. The common factual issue is that if there was a differential between the market price at the trading center and the posted price greater than the value added by its movement to the market center. The legal issue is, if this differential was greater than the value added, who was entitled to the profit?

The plaintiff's expert witness, Dr. Leitzinger, estimated the damages from 1986 to 1998. Including interest, the estimate of damages due to alleged underpayments by Global Defendants amounted to $\$ 358.8$ million. ${ }^{386}$ Under the Global Settlement the first tier royalty owners recovered $\$ 116.19$ million, $32 \%$ of their estimated damages. The court accepted these calculated figures because it later stated "compared

386 In re Lease Oil Antitrust Litig., 186 F.R.D. at 434 . 
with other complex commercial class action settlements, a recovery of over $32 \%$ is substantial." 387

Each of the settlements in this case had established a common fund for the benefit of the nationwide class of royalty and working interest owners of the crude oil companies and the funds totaled over $\$ 190$ million. Each settlement provided that attorney's fees will not exceed 25\% of the settlement Amount. ${ }^{388}$ The Court acknowledged that "the plaintiff attorneys have had to work harder to represent this class due to its size and diversity; they have not simply benefited from the fact that, a single tortuous act harmed millions of people rather than thousands." ${ }^{389}$ It stated that the case required such a large initial investment by the attorneys, and was made more difficult due to the sheer number and variety of

387 See In re Domestic Air Transp. Antitrust Litig., 148 F.R.D. 297, 325 (N.D. Ga. 1993). The court in that case stated that applying the range of value of the combined settlement, the court finds that the settlement in this action amounts to approximately 12.7-15.3\% of the estimated \$2 billion minimum possible untrebled recovery.

388 In re Lease Oil Antitrust Litig., 186 F.R.D. at 434. The Fifth Circuit in Johnson recommended 12 factors for the district courts to use as they reconsidered the award: 1) time and labor required; 2) the novelty and difficulty of the questions involved; 3 ) the skill required to perform the legal service properly; 4) the preclusion of other employment by the attorney due to acceptance of the case; 5) the customary fee; 6) whether the fee is fixed or contingent; 7) time limitation imposed by the client or the circumstances; 8) the amount involved and results obtained; 9) the experience, reputation and ability of the attorneys involved; 10) the "undesirability" of the case; 11) the nature and length of the professional relationship with the client; and 12)awards in similar cases. See Johnson v. Georgia Highway Express, 488 F.2d 714, 717-19 (5th Cir. 1974).

389 In re Lease Oil Antitrust Litig., 186 F.R.D. at 447. 
members. ${ }^{390}$ The Court concluded by stating that since the attorneys had done extraordinary work, had tackled novel issues, and had gained a relatively high recovery and substantial benefit for the class, and since the size of the settlement did not warrant a drastic reduction in the percentage of the fee in these circumstances, the attorneys' fee award of $25 \%$ was accepted. ${ }^{391}$

With respect with the second Tier Claimants, the expert witness calculated the oil barrels were damaged by 32 cents per barrel while those barrels were damaged by 49 cents per barrel. The Claimants would then receive 3\% of their estimated damages for early barrels and 13\% of their estimated damages for late barrels. Thus, the Plaintiffs could recover \$48 million for the Claimants under the Global settlement. The Court found that the recovery aspects of the Global Settlement were fair, adequate and reasonable.

390 Id.

391 Id. at $448-49$. 
Netscape Comm. Corp. V. Microsoft Corp., Per Local Civil Rule 40.5, Related to Civil Action Nos. 98-1232 and 98-1233 (D.D.C. $2002)(a / k / a$ AOL v. Microsoft).

The settlement of the lawsuit brought by Netscape Communications against Microsoft is noteworthy because (1) it was in large part a follow on private suit to the combined federal and state government suit against Microsoft ${ }^{392}$ (2) it resulted in a cash settlement of $\$ 750$ million $^{393}$; (3) the parties who were once fierce competitors have agreed to become collaborators of software and distribution of each other's products $^{394}$; and (4) it leaves outstanding the issue of anticompetitive consequences for consumers of Microsoft's continuing domination in the browser and operating system markets. ${ }^{395}$

In the mid 1990's Netscape Navigator, an internet browser, was dominant with over a $70 \%$ share in the browser

392 United States V. Microsoft, Nos. 98-1232 \& 98-1233 (D.D.C. $1998)$.

393 David D. Kilpatrick \& Steve Lohr, Microsoft to Pay AOL \$750 Million; End to 'Long War,' New York Times A6 (May 30, 2003); David E. Vise, Microsoft, AOL Bridge Digital Divide, Washington Post E1 (May 30, 2003); Julia Angwin, Robert A. Guth, and John R. Wilke, Microsoft settles AOL Browser Suit Software Maker to Pay $\$ 750$ million to Its Rival, Wall street Journal A3 (May, 20, 2003).

394 Id.

395 A Big Deal; Microsoft and AOL Time Warner, The Economist, June 7,2003 at 67 . 
market. ${ }^{396}$ Netscape was unique as it could be run on different operating systems as well as it could be used as a platform itself to write software applications. ${ }^{397}$ The emergence of this new browser worried executives at Microsoft. ${ }^{398}$ Their main fear was that Netscape would threaten their Windows monopoly in the operating system market. ${ }^{399}$

Windows is the dominant operating system as it is used in more than $90 \%$ of the $\mathrm{PC}^{\prime} \mathrm{s}$ in this country. ${ }^{400}$ Its dominance is mainly attributed to the fact that it can run a large number of software applications, many of which are written to run exclusively on Windows. ${ }^{401}$ Consequently, Microsoft never faced a threat from a competing operating system. ${ }^{402}$ However, with the emergence of Netscape, Microsoft now faced a threat that a browser that can be run on any operating system could be used

\footnotetext{
396 Government's Complaint at 2, United States V. Microsoft Corp. (D.D.C. 1998) (Nos. 98-1232\&98-1233).

397 Id. at 3.

398 Id.

399 Id.

400 Id. at 1 .

401 Id.

402 Id.
} 
as a rival platform that could run software programs. ${ }^{403}$

Therefore, the multi-billion dollar Windows monopoly was in jeopardy .

What ensued was the so-called "browser wars" in which Microsoft sought to minimize the threat to its Windows monopoly by increasing its share of the browser market. ${ }^{404}$ Microsoft's browser, Internet Explorer, was the alternative to Netscape and an extensive campaign was launched to market it. ${ }^{405}$

This campaign garnered the attention of Department of Justice, who along with Attorney Generals from 19 different states filed suit against Microsoft in 1998. ${ }^{406}$ After more than a year of proceedings the District Court for the District Columbia issued its findings of facts and conclusions of law that Microsoft had engaged in an anticompetitive campaign against Netscape. ${ }^{407}$ Following the conclusions found in the government's case, American Online (AOL), which had purchased

\footnotetext{
403 Id. at 2 .

404 Id. at 4 .

405 Id.

406 Plaintiff's Complaint at 8, Netscape Comm. Corp. V. Microsoft Corp., Per Local Civil Rule 40.5, Related to Civil Action Nos. 98-1232 and 98-1233 (D.D.C. 2002).

407 Id.
} 
Netscape, privately sued Microsoft. ${ }^{408}$ AOL's allegations substantially mirrored the government's complaint of Microsoft's anticompetitive conduct. ${ }^{409}$

Specifically, they made several allegations. First, they accused Microsoft of tying Internet Explorer to the Windows operating system ${ }^{410}$. Second, they alleged exclusionary agreements that prevented other companies from selling, buying, marketing or using Netscape Navigator. ${ }^{411}$ Lastly, they alleged that Microsoft monopolized and attempted to monopolize the PC operating system and browser markets. ${ }^{412}$

In May 2003, AOL and Microsoft reached a settlement. ${ }^{413}$

The two companies had agreed to several terms. First, Microsoft was to pay AOL $\$ 750$ million. ${ }^{414}$ Second, AOL will receive a seven year, royalty free use of Internet Explorer on its online service as well as long term license to use

408 Id. at 1 .

409 Id. at 12-19.; United States V. Microsoft (D.D.C. 1998 ) (Nos. 98-1232\&98-1233).

410 Id.

411 Id. at $5-6$.

412 Id. at $15-16$

413 David D. Kilpatrick \& Steve Lohr, Microsoft to Pay AOL \$750 Million; End to 'Long War,' New York Times A6 (Mar. 30, 2003). 414 Id. 
Microsoft's media software. ${ }^{415}$ Third, Microsoft agreed to distribute AOL CD ROM's to Original Equipment Manufacturers around the world. ${ }^{416}$ Lastly, both companies agreed to make each other's instant messaging services interoperable with one another. ${ }^{417}$

Overall, Microsoft and AOL have entered into a win-win collaborative effort. Microsoft will be able to further expand the dissemination and use of its software into even more markets. ${ }^{418}$ On the other hand, AOL is able to get a badly needed infusion of cash as it was $\$ 25$ billion in debt. ${ }^{419}$ Moreover, AOL was able to expand the dissemination of its fledgling internet service as well as expand its appeal with the royalty free use of Microsoft software. ${ }^{420}$

While the settlement might be a good deal for both companies, what about the consumers? Critics have charged that

415 Id.

416 Julia Angwin, Robert A. Guth \& John R. Wilke, Microsoft Settles AOL Browser Suit --- Software Maker to Pay $\$ 750$ Million to Its Rival; Wide Collaboration Is Set, Wall street Journal A3 (Mar. 30, 2003).

417 Id.

418 A Big Deal; Microsoft and AOL Time Warner, The Economist, June 7,2003 at 67 .

419 Id.

420 Id. 
this settlement is only about the two companies' future in digital media and not about past anticompetitive behavior. ${ }^{421}$ Furthermore, this settlement might be the "final nail in the Netscape Coffin."422 This is so because this settlement does nothing to address Internet Explorer's continuing domination in the browser market. ${ }^{423}$ Therefore, consumers are still left with little choice in both the browser and operating system markets. ${ }^{424}$

421 Id.

422 Id.

423 Id.

424 Id. 
Oncology \& Radiation Associates V. Bristol-Meyers Squibb Co., Case No. 1:04CV00248 (D.D.C.) (Taxol).

This case is notable because: 1. The class obtained a $\$ 65,815,000.00$ settlement in a section 2 rule of reason action; 2 . This was a private action which preceded government actions against the manufacturer.

Bristol Myers Squibb (BMS) manufactures a chemotherapy drug under the brand name, Taxol. ${ }^{425}$ The active ingredient in Taxol is paclitaxel. ${ }^{426}$ BMS developed paclitaxel during a research venture with the National Cancer Institute. ${ }^{427}$ The National Cancer Institute awarded BMS the right to manufacture paclitaxel exclusively for five years. ${ }^{428}$

When the exclusivity period ended, generic competitors attempted to enter the paclitaxel market. ${ }^{429}$ Generic drugs have the same therapeutic value and active ingredients as

425 Notice of Proposed Settlement of Class Action And Hearing Regarding Settlement, Oncology \& Radiation Associates $v$. Bristol Myers Squibb Co. and American Bioscience, Inc., No. 1:01CV02313 (EGS) at 2 (D.D.C. May 13, 2003) (available at http: / / www . completeclaimsolutions.com/taxol/pdf/notice.pdf) .

426 Patrick Cafferty, Miller Faucher \& Cafferty LLP, Collusion and Other Anticompetitive Practices: A Survey of Class Action Lawsuits Against Drug Manufacturers 21, http://www.familiesusa .org/assets/pdfs/3rd_edition_lawsuit_surveys_pmd30c3.pdf (January 2004).

427 Id.

428 Id.

429 Id. 
their brand name counterparts. 430 However, generic drugs cost significantly less than their name brand counterparts. ${ }^{431}$

Direct purchasers of paclitaxel filed suit against BMS in 2001. ${ }^{432}$ The suit alleged that BMS engaged in anticompetitive conduct in order to keep generic equivalents of Taxol off the market from January 1999 to March 2003. ${ }^{433}$ Specifically, direct purchasers argued that BMS abused the FDA patent process by filing frivolous lawsuits against generic drug manufacturers, and paid off would-be competitors to stay out of the paclitaxel market. ${ }^{434}$ some have estimated during this period, BMS made \$3 million each day on Taxol. ${ }^{435}$

430 FTC, FTC Charges Bristol-Myers Squibb with Pattern of Abusing Government Processes to stifle Generic Drug Competition, http://www.ftc.gov/opa/2003/03/bms.htm (March 7, 2003 ).

431 Id.

432 Notice of Proposed Settlement of Class Action And Hearing Regarding Settlement, Oncology \& Radiation Associates $v$. Bristol Myers Squibb Co. and American Bioscience, Inc., No. 1:01CV02313 (EGS) at 2 (D.D.C. May 13, 2003). (available at http://www.completeclaimsolutions.com/ taxol/pdf/notice.pdf).

433 Id.

434 Id.

435 Common Cause, Prescription For Power: How Brand Name Drug Companies Prevailed Over Consumers in Washington, http: //www.hatch2006.org/positionpapers/ppPharmaceuticalReport .html\#_4 (June 12, 2001). 
Drug manufacturers have to record patents related to brand name drugs in the FDA publication referred to as the "Orange Book". ${ }^{436}$ When a generic drug manufacturer seeks FDA approval, the generic manufacturer must certify to the FDA that the drug will not infringe upon any patents in the Orange Book. ${ }^{437}$ The generic manufacturer must put the brand name manufacturer on notice of its intentions to introduce a generic equivalent. ${ }^{438}$ If, within 45 days, the brand name drug manufacturer files a patent infringement suit against the generic drug manufacturer, the FDA automatically delays entry of the generic drug into the market for thirty months. ${ }^{439}$ The purchasers alleged that BMS abused this process, by filing a series of baseless patent infringement suits in order to delay generic competitors from entering the market. ${ }^{440}$

In addition to filing frivolous patent suits in order to delay the entry of generic paclitaxel, the plaintiffs also alleged that BMS colluded with American Bioscience Inc. (ABI),

\footnotetext{
436 FTC, FTC Charges Bristol-Myers Squibb with Pattern of Abusing Government Processes to Stifle Generic Drug Competition, http://www.ftc.gov/opa/2003/03/bms.htm (March 7, 2003 ).

437 Id.

438 Id.

439 Id.

440 Id.
} 
a generic manufacturer, to settle its "sham" patent case. BMS settled this case with ABI for over $\$ 70$ million in exchange for ABI's promise that it would refrain from obtaining a patent for generic paclitaxel. ${ }^{441}$

The direct purchasers filed suit against BMS and ABI in November 2001, and the parties settled the suit on August 14, 2003. ${ }^{442}$ The class of direct purchasers received $\$ 65,815,000.00 .{ }^{443}$ BMS paid $\$ 65$ million, and ABI paid $\$ 815,000.00 .444$

The Court noted that by the time the parties reached a settlement, private counsel had undertaken an "intensive" investigation, examined thousands of pages of documents, retained and consulted with experts; and had "significant"

441 FTC, FTC Charges Bristol-Myers Squibb with Pattern of Abusing Government Processes to Stifle Generic Drug Competition, http://www.ftc.gov/opa/2003/03/bms.htm (March 7, 2003 ).

442 Cohen, Milstein, Hausfeld \& Toll, Antitrust, http://www.cmht.com/antitrust.php (accessed June 4, 2006).

443 Notice of Proposed Settlement of Class Action And Hearing Regarding Settlement, Oncology \& Radiation Associates $v$. Bristol Myers Squibb Co. and American Bioscience, Inc., No. 1:01CV02313 (EGS) at 2 (D.D.C. May 13, 2003) (available at http: //www. completeclaimsolutions.com/taxol/pdf/notice.pdf) . 444 Id. 
knowledge of issues such as liability, causation, and damages. ${ }^{445}$ The attorneys were awarded $30 \%$ in legal fees. ${ }^{446}$

Following the commencement of this private action in 2001, several government actions were brought against BMS on behalf of indirect purchasers. ${ }^{447}$ In 2002 , several states and the District of Columbia filed suits against BMS. ${ }^{448}$ The Federal Trade Commission filed a complaint against BMS in 2003, alleging the same anticompetitive conduct. ${ }^{449}$ This case was resolved when the FTC and BMS entered into a consent order in which BMS agreed to cease its anticompetitive practices in order to hamper the entry of generic drugs into the paclitaxel

445 Notice of Proposed Settlement of Class Action And Hearing Regarding settlement, Oncology \& Radiation Associates $v$. Bristol Myers Squibb Co. and American Bioscience, Inc., No. 1:01CV02313 (EGS) at 2 (D.D.C. May 13, 2003) (available at http: //www. completeclaimsolutions.com/taxol/pdf/notice.pdf ).

446 Email from Steig Olson, Esq. to Tara Shoemaker, Re: Oncology \& Radiation Associates PA Litigation (June 5, 2006 ).

447 Notice of Proposed Settlement of Class Action And Hearing Regarding Settlement, Oncology \& Radiation Associates $v$. Bristol Myers Squibb Co. and American Bioscience, Inc., No. 1:01CV02313 (EGS) at 2 (D.D.C. May 13, 2003) (available at http: / /www. completeclaimsolutions.com/taxol/pdf/notice.pdf).

448 Terry Carter, A Deluge of Lawsuits 88 A.B.A.J. 45 (December, 2002).

449 FTC, Plaintiff's Complaint In the Matter of Bristol-Myers Squibb 26, http://www.ftc.gov/os/2003/04/bristolmyerssquibbcmp.pdf (April 14, 2003). 
market. ${ }^{450}$ When generic paclitaxel finally entered the market, Taxol sales fell by $50 \%{ }^{451}$

450 Marcus Meier, Overview of FTC Antitrust Actions In Health Care Services And Products 4, http://www.ftc.gov/bc/ 0604hcupdate.pdf (April 2006).

451 FTC, FTC Charges Bristol-Myers Squibb with Pattern of Abusing Government Processes to Stifle Generic Drug Competition, http://www.ftc.gov/opa/2003/03/bms.htm (March 7, 2003). 
Stop $N$ Shop Supermarket Company, et. al.v. Smithkline Beecham Corp. Civil Action No. 03-CV-4578 (E.D. Pa. 2005), and; Nichols V. SmithKline Beecham Corp., No. 00-CV-6222 (E.D. Pa.2005) (Paxil)

These cases are notable because: 1: The Stop $N$ Shop direct purchaser case resulted in a "megafund" settlement of \$100 million dollars; 2: The Court awarded Plaintiffs' Counsel in the Stop $N$ Shop case $20 \%$ of the megafund settlement because of the extraordinary quality of their work; 3: Plaintiffs in the Nichols case, an indirect purchaser action, received a settlement of $\$ 65$ million against Defendant Smithkline Beecham for the same anticompetitive conduct, and awarded counsel a 30\% fee; 4: The Plaintiffs in both cases coordinated discovery during the litigation; 5: These cases were brought against Smithkline Beecham under section 2 of the Sherman Act, in the absence of any formal government investigation or lawsuit.

The plaintiffs in stop $N$ shop supermarket were direct purchasers of Paxil. The Plaintiffs in Nichols were indirect purchasers of Paxil. Defendant Smithkline Beecham ("SKB") manufactured the antidepressant drug paroxetine hydrochloride under the brand Paxil. 
The plaintiffs claimed one count of monopolization under the Section 2 of the Sherman Act. ${ }^{452}$ Both classes of plaintiffs alleged that SKB abused the FDA patent approval process in order to illegally maintain its Paxil monopoly. Because SKB developed the drug, the company was entitled to a five-year statutory monopoly under FDA policy. ${ }^{453}$ After this exclusivity period ended, SKB filed numerous patent infringement lawsuits against generic drug manufacturers that attempted to enter the paclitaxel market. ${ }^{454}$

The plaintiffs argued that SKB filed these "sham" lawsuits to illegally maintain their monopoly in the paroxetine market and fix prices. ${ }^{455}$ The stop $N$ shop direct purchaser plaintiffs estimated that $\mathrm{SKB}^{\prime} \mathrm{s}$ anticompetitive conduct cost them $\$ 880$ million in damages. ${ }^{456}$ The indirect purchaser plaintiffs in the Nichols case estimated the

\footnotetext{
452 Id at 8 .

453 J. Padova, Memorandum accompanying Order Granting Attorneys' Fees, Stop $N$ Shop Supermarket, et. al., p.1. May 19,2005 .

454 Id at 2 .

455 Id at 2 .

456 Id at 21 .
} 
overcharge that SKB passed along to consumers to be 35 percent. ${ }^{457}$

During discovery, SKB was facing two lawsuits alleging the same anticompetitive conduct, the Stop $N$ shop case brought by direct purchasers, and, the Nichols case brought on behalf of indirect purchasers. ${ }^{458}$ Plaintiffs' counsel in both cases coordinated discovery with each other, leading to a timely result in stop $N$ Shop. ${ }^{459}$ Both of these private cases were brought against SKB without of any prior government case or even a formal investigation. ${ }^{460}$

The Stop $N$ Shop case settled about one year after its inception. Plaintiffs' counsel filed the Motion For Class Certification and the Motion For Preliminary Approval of Settlement with the District Court on the same day. ${ }^{461}$ The $\$ 100$ miliion settlement represented about $11 \%$ of their

${ }^{457}$ Smithkline Beecham: News of FTC Probe Triggers Dual Suits Over Paxil, Class Action Reporter, December 14, 2000 Vol. 2, No. 142 .

458 Id. at 9 .

459 Id. at 9.

460 Id. at 29 .

461 J. Padova, Memorandum accompanying Order Granting Attorneys Fees, stop N Shop Supermarket V. Smithkline Beecham Corp., p. 13, May 19, 2005. 
estimated damages. ${ }^{462}$ This was a "megafund" settlement, meaning that the case resulted in a recovery of \$100 million or more.

Attorneys' fees are typically awarded on a sliding scale, with the percentage awarded decreasing as the amount of recovery increases. ${ }^{463}$ Plaintiffs' counsel requested $30 \%$ of the settlement fund, ${ }^{464}$ and none of the 90 sophisticated corporations which comprised the direct purchaser class objected to counsels' request for $30 \% .{ }^{465}$

Ultimately, however, the Court awarded $20 \%$ of the settlement fund to Plaintiffs' counsel. ${ }^{466}$ The Court observed that "the litigation presented enormously complex legal and factual issues...moreover, this action was riskier than many other antitrust actions because there was no prior government investigation, or prior finding of civil or criminal liability based on antitrust violations" ${ }^{467}$

\footnotetext{
462 Id. at 21 .

463 Id. at 22 .

464 Id. at 24

465 Id. at 35 .

466 Id. at 44

467 PA Judge Slashes Fees in Paxil Case, Class Action Reporter, June 1, 2005, Vol 7, No. 107
} 
Although the number of hours plaintiffs' counsel spent on the case was relatively small, Judge Padova commented, "The court recognizes that plaintiffs' counsel should not be penalized for prosecuting this case in an efficient manner, or for keeping down the number of hours which they were required to devote to this case by coordinating merits discovery with plaintiffs' counsel" (in the indirect purchaser case) $\cdot{ }^{468}$

Judge Padova expressed the idea that although it is typical for courts to decrease the percentage amount awarded for attorneys' fees as the settlement amount increases, there is no hard and fast rule. In a case such as this, a 20\% award was justified because class counsel's work was so "timely and well done". ${ }^{469}$

Judge Padova also granted attorneys fees in the Nichols case. From the \$65 million settlement, Plaintiffs' Counsel received $\$ 19.5$ million dollars, which is $30 \% .470$ Attorneys in the Nichols case spent more than 17,000 hours working on the

468 J. Padova, Memorandum accompanying Order Granting Attorneys Fees, p. 30, Stop $N$ Shop Supermarket v. Smithkline Beecham Corp., May 19, 2005.

469 Id.

470 PA Judge Slashes Fees in Paxil Case, Class Action Reporter, June 1, 2005, Vol 7, No. 107 
case to reach the settlement. ${ }^{471}$ It is believed that SKB paid millions more to private plaintiffs that opted out of the class actions in confidential settlement agreements. ${ }^{472}$

471 Id.

472 Id. 
In Re: Polypropylene Carpet Antitrust Litigation, 93 F. Supp. 2d 1348 (N.D. Ga. 2000).

The polypropylene litigation is important because 1. it started with a different private antitrust suit, that led to a government conviction, that led to this litigation; 2 . the government suit led to a judicial finding of price fixing and an executive serving prison time; 3) the cases involved a nationwide class action, 4) the settlements totaled $\$ 49.7$ million; 4) Legal fees were $331 / 3 \%$ plus expenses.

In 1993 Diamond Rug \& Carpet Mills, a private carpet and fibermaker sued Shaw Industries, ${ }^{473}$ the nation's largest publicly traded carpetmaker, for illegal monopolization. ${ }^{474}$ The suit alleged that Shaw had illegal monopolies in the manufacture of residential carpet and polypropylene fiber, that shaw tried to lure Diamond into a price-fixing scheme, and that shaw cajoled Dupont, the maker of the widely popular treated nylon carpet fiber called stainmaster, into refusing to sell the Stainmaster fiber to Diamond. ${ }^{475}$

\footnotetext{
${ }^{473}$ See Susan Harte, Suit Threatens Fiber of Carpet Industry, Shaw Accused of Holding Monopolies, AtlantA J. And Const., July 6 , 1993, at E1.

${ }^{474} \mathrm{Id}$.

${ }^{475}$ Id.
} 
The suit against Shaw attracted the attention of the Justice Department, and it began investigating several carpet makers that used Dupont's Stainmaster nylon carpet fiber, including Beaulieu of America, Mohawk Industries, and Sunrise Carpet Industries. ${ }^{476}$ In late 1994, Diamond and Shaw settled their suit and had the results sealed. ${ }^{477}$

On June 7, 1995 the Justice Department brought charges against Sunrise Carpet Industries and its Chairman, Johnny A. West. The charges stated that Sunrise and Mr. West "engaged in a combination and conspiracy to fix, raise, and maintain prices of twenty-ounce level-loop polypropylene ("poly") carpet in the United States" between October 1992 and, at least, June 1993 which violated Section 1 of the Sherman Act. ${ }^{478}$

Sunrise and Mr. West plead guilty to one count of price fixing, and a federal judge sentenced Mr. West to a twelve

\footnotetext{
${ }^{476}$ See Susan Harte, Shaw-Diamond Quarrel Possible Trigger, Atlanta J. And Const., December 14, 1995, at 6F.

477 See Beenea A. Hyatt, Firms Pile on Carpet Lawsuit; Federal Case To Go To Trial By 1999, ChatTAnooga Times, October 8, 1997, at $\mathrm{B} 1$.

478 Complaint, U.S. V West (N.D. Ga. 1995) (1:95-CR-240). Sunrise and Mr. West also were accused of agreeing with fellow carpet makers to charge prices above certain levels on polypropylene carpet and of communicating with fellow carpet makers on prices for polypropylene carpets. Id.
} 
month prison sentence and fined him $\$ 150,000$; Sunrise was fined $\$ 750,000 .{ }^{479}$

A civil complaint was then filed by seventeen plaintiffs, who were direct purchasers, against Sunrise Industries, and in December 1995 six other carpet makers were added as defendants to the suit. ${ }^{480}$ The new defendants included Shaw Industries, Mohawk Industries, and Beaulieu of America, the three largest carpet makers in the country. ${ }^{481}$ In 1997, the U.S. District Court for the Northern District of Georgia granted the plaintiffs' Motion to Certify Class Action, ${ }^{482}$ and it was estimated that were potentially 4,000 to 5,000 plaintiffs in the suit.

After class certification, the litigation proceeded and the next major development was in 2000 when the court ruled on

\footnotetext{
${ }^{479}$ The sentencing judge stated that "Mr. West provided complete information about a multi-corporation price-fixing scheme," but there were no more indictments brought forth by the Department of Justice. The Department of Justice closed its investigation of price fixing in the carpet industry in 1997. See Susan Harte, Sunrise Carpet Chief Sentenced in Antitrust Case, Atlanta J. And Const., September 16, 1995, at 3B.

${ }^{480}$ See Don Plummer, Carpet Pricing Challenged; An Expanded Lawsuit Now Targets the Industry's Biggest Manufacturers, AtLANTA J. AND Const., December 14, 1995, at 1F.

481 In 1995, Shaw Industries had \$2.96 billion in annual sales, Mohawk Industries: \$1.64 billion, and Beaulieu of America: $\$ 903$ million. Id.

482 See In Re: Polypropylene Carpet Antitrust Litigation, 996 F. Supp 18 (N.D. Ga. 1997).
} 
the Defendants' Motion to Exclude Expert Testimony. ${ }^{483}$ The Plaintiffs intended to introduce the testimony of an economist to "analyze whether the conditions in the polypropylene carpet market during a particular period were consistent with competitive or collusive activity;"484 and an econometrician who had developed a model "to forecast competitive prices during the time period at issue, and identify any difference between the actual prices of polypropylene carpet and the forecasted competitive prices during that period."485 The expert estimated that there has been an overcharge of $8.3 \%$ by Defendants which resulted in the Plaintiffs being overcharged $\$ 222,963,542 .{ }^{486}$ The court concluded that the Plaintiffs' expert witnesses satisfied the Daubert criteria and denied Defendants' Motion to Exclude Testimony. ${ }^{487}$

Shortly after the court's decision regarding the expert witnesses, Shaw Industries and Mohawk Industries announced they had agreed to settle the lawsuit. Shaw agreed to pay $\$ 27.5$ million and Mohawk agreed to pay $\$ 13.5$ million. ${ }^{488} \mathrm{~A}$

\footnotetext{
${ }^{483}$ See In Re: Polypropylene Carpet Antitrust Litigation, 93 F. Supp. 2d 1348 (N.D. Ga. 2000).

${ }^{484}$ Id. at 1351 .

${ }^{485} \mathrm{Id}$.

${ }^{486}$ Id. at 1360.

${ }^{487}$ Id. at $1370,1352$.
} 
year later, in March 2001, Beaulieu of America also agreed to settle for $\$ 8.7$ million. ${ }^{489}$ The final aggregate settlement amount was $\$ 49.7$ million.

After the settlement was reached, Judge Murphy granted the Plaintiffs motion for attorneys' fess and reimbursement. The court awarded the attorneys fees in the amount of $331 / 3 \%$ of the total settlement fund plus accrued interest. The court also awarded the attorneys $\$ 3,329,622.52$ in out-of-pocket expenses.

${ }^{488}$ See Patti Bond, Shaw, Mohawk Will settle in Carpet PriceFixing Suit, Atlanta J. And Const., August 12, 2000 , at 3F. ${ }^{489}$ See Beaulieu of America Settles Antitrust Class Actions, THE WEEKLY NEWSPAPER FOR THE HOME FURNISHING NETWORK, March 5, 2001 , at 32. 
RealNetworks, Inc. V. Microsoft Corp., Civil Action No. JFM04-968, MDL Docket No. 1332 (D. Md.) (2005 settlement)

This settlement of the lawsuit brought by RealNetworks, Inc., ("Real") against Microsoft Corporation ("Microsoft") is noteworthy because (1) it was the last of the major competitor lawsuits pending against Microsoft; (2) the recovery will be at least $\$ 478$ million, and possibly as much as \$761 million, depending on how many subscribers Real receives from its collaborative efforts on MSN; (3) the parties agreed to cooperate on the creation and distribution of what had previously been competing products; and (4) it resulted in the withdrawal of claims against Microsoft before competition authorities in the European Union ("EU") and South Korea ("Korea") as well as the dismissal of Real's complaint, involving section 1 and 2 claims, in the United states. This was not a "follow on case" to the Department of Justice's ("DoJ") earlier lawsuit against Microsoft, although it alleged similar misconduct by Microsoft. The DoJ case concerned Microsoft's bundling of its web browser with the Windows operating system ("Windows"). Real's lawsuit, on the other hand, concerned a different product, i.e., Microsoft's bundling of the media player with Windows. In this sense, RealNetwork's lawsuit could be called a "follow on case" to the EU's preliminary decision in August 2003 that Microsoft's 
bundling violated the EU's competition law. ${ }^{490}$ RealNetworks had participated in the EU proceedings as a witness, ${ }^{491}$ and in October 2004 RealNetworks filed a complaint with the Korea Fair Trade Commission (KFTC) regarding Microsoft's bundling of the media player. ${ }^{492}$

Real filed the lawsuit against Microsoft on December 18, 2003. ${ }^{493}$ Microsoft and Real competed directly against each

$490 \mathrm{C} \mid$ Net, EU Closes in on Microsoft Penalty (Aug. 6, 2003), available at http: //news. com.com/EU+closes+in+on+Microsoft+penalty/21001016_3-5060463.html. In March 2004, a final decision against Microsoft was issued. Commission Decision No. COMP/C-3/37.792 (2004) (Microsoft). Indeed, Real CEO Ron Glaser told shareholders in a cover letter to the 2003 Annual report that the "recent European Commission ruling against Microsoft regarding its media player bundling practices reinforces" the company's view "that the merits of our case are relatively strong and that the funds spent pursuing this litigation will be money well spent." RealNetworks, Inc., 2003 Annual Report $115(2004)$.

491 Seattle Post-Intelligencer, RealNetworks sues Microsoft (Dec. 19, 2003), avaliable at http://seattlepi.nwsource.com/business/153239_realsuit19.html.

492 InfoWorld, Korea to hear Microsoft Competition case (July 8, 2005) available at http: //www. infoworld. com/archives/emailPrint.jsp?R=printThis\&A =/article/05/07/08/HNmskorea_1.html. Ultimately, the KFTC fined Microsoft and ordered the firm to remedy its bundling practices. InfoWorld, Update: Microsoft fined $\$ 32 M$ by South Korea (Dec. 7, 2005) available at http://www. infoworld. com/archives/emailPrint.jsp?R=printThis\&A =/article/05/12/07/HNmicrosoftfined_1.html.

493 RealNetworks, Inc., v. Microsoft Corp., Complaint, No. C035717 (JW) (EAI) (N.D. Cal. 2003). The case was subsequently transferred to Judge Motz of the United States District Court for the District of Maryland, who was hearing most of the 
other, as well as Apple and Macromedia (now a subsidiary of Adobe), in the media player, server and digital rights management ("DRM") markets. ${ }^{494}$

Although not a true "follow on case" to the DoJ litigation, Real's complaint relied heavily on the findings from the DoJ's case against Microsoft, and alleged that Microsoft deliberately pursued the same tactics against Real's products, e.g., bundling of competitive products with Windows, exclusive dealing contracts with PC manufacturers and content providers for Microsoft products, preventing consumers from removing Microsoft's media player, denying Real access to technical information, etc., that Microsoft successfully used against Netscape's web browser. Real alleged that the conduct enabled Microsoft to maintain its monopoly in PC operating systems as well as to create a monopoly in various digital media markets in violation of the sherman and Cartwright Acts. More specifically, Real claimed illegal monopoly maintenance in the operating systems market attempted monopolization of the digital media markets under section 2 of the Sherman Act, as well as tying of the media player and the streaming media

follow on cases to the DoJ's action against Microsoft. See, RealNetworks, Inc., V. Microsoft Corp., No. JFM-04-968, MDL Docket No. 1332 (D. Md.).

494 Michael J. DeMaria, Screaming Streaming Media, Network Computing, Feb. 2006, at 47. Interestingly, Real's complaint does not list Macromedia as a competitor. Complaint, at 10 . 
server to the desktop and server operating systems and exclusive dealing under Section 1 of the Sherman Act. ${ }^{495}$ Real sought both damages and injunctive relief.

Real's Annual Report for 2005 revealed that it had spent $\$ 1.6$ million on legal fees for the case $2003, \$ 11$ million in 2004, and \$55 million in $2005 .^{496}$ Real received $\$ 478$ million from Microsoft in 2005. ${ }^{497}$ In the "Shareholder Letter" contained in the 2005 Annual Report, CEO Ron Glaser noted that the settlement had "substantially enlarged" Real's profit for 2005. More precisely, the company would not have "returned to GAAP profitability" without the settlement. ${ }^{498}$ But for the $\$ 478$ million from Microsoft, Real would have suffered a \$166 million net loss for 2005. ${ }^{499}$

In addition to the $\$ 478$ million paid to Real in 2005, Microsoft agreed to pay Real an additional \$283 million over

495 RealNetworks, Inc., v. Microsoft Corp., Complaint, No. C03$5717(\mathrm{JW})$ (EAI) 46-55 (N.D. Cal. 2003).

496 RealNetworks, Inc., 2005 Annual Report 28 (2006). These were not immaterial costs for RealNetworks. The legal fees equaled 1\% of Real's total net revenue for 2003, 4\% for 2004, and $17 \%$ of the net revenue for 2005 . Id. at 31 .

497 RealNetworks, Inc., 2005 Annual Report 30 (2006). The settlement payment exceeded net revenues in 2005 by $\$ 153$ million. Id. at 28,30 .

498 "Shareholder Letter, " reprinted in RealNetworks, Inc., 2005 Annual Report (2006).

499 RealNetworks, Inc., 2005 Annual Report 28 (2006). 
the next two years. ${ }^{500}$ Microsoft also agreed to "promote and integrate" Real's music and game services with Microsoft's MSN network. ${ }^{501}$ The $\$ 283$ million may be reduced depending on how many subscribers Real receives from the collaborative efforts on MSN. ${ }^{502}$ Microsoft agreed to provide Real with technical data and assistance in software development, ${ }^{503}$ but Microsoft did not agree to end its bundling practices or to allow users to remove the media player from Windows. ${ }^{504}$

Other than returning the company to profitability for the first time since 1999, it is not clear that the settlement achieved its objectives. For example, the 2005 Annual Report states that the company "cannot predict whether consumers will adopt or maintain our media player products ..., especially in light of the fact that Microsoft bundles its competing Windows Media Player with its Windows operating system."505 Similarly,

\footnotetext{
500 RealNetworks, Inc., 2005 Annual Report 30 (2006).

501 "Shareholder Letter," reprinted in RealNetworks, Inc., 2005 Annual Report (2006).

502 RealNetworks, Inc., 2005 Annual Report 30 (2006).

503 See Exhibit D to the Settlement Agreement Between Microsoft Corporation and RealNetworks, Inc.: Windows Technology Commitments in RealNetworks Inc., Form 10-K, Exhibit 10.24, "Amended and Restated Settlement Agreement" (March 16, 2006). 504 RealNetworks, Inc., 2005 Annual Report 13 (2006). 505 RealNetworks, Inc., 2005 Annual Report 13 (2006).
} 
the Annual Report noted that notwithstanding the settlement, "Microsoft will continue to be an aggressive competitor" 506 and Microsoft's "dominant position" as well as "its aggressive activities ... will likely continue to have ... adverse effects on our business and operating results." 507

506 RealNetworks, Inc., 2005 Annual Report 14 (2006).

507 RealNetworks, Inc., 2005 Annual Report 16 (2006). 
Red Eagle Resources, et al. V. Baker Hughes Inc., et al., No. 4:91Cv00627 (Docket) (S.D.Tex. Mar. 11, 1991)(In re Drill Bits Antitrust Litigation)

Summary: These related cases concern an agreement between four of the major drill bit manufacturers to artificially fix prices of roller cone drill bits used in drilling oil and gas wells. They are noteworthy because: 1) the primary source of the litigation was a private suit. Despite the fact that the Drill Bits Litigation followed a government investigation, the government investigation had been prompted by a private suit; 2) Two of the private settlements preceded guilty pleas and settlements in their criminal counterpart; 3) Counsel achieved a settlement with Dresser Industries, a drill bit manufacturer not included in the government suit; 4) The total settlement was for \$53.4 million dollars; and 5) Counsel was awarded a fee of $30.8 \%$

This case can be traced back to a private suit between two drill bit manufacturers, Rockbit International of Fort Worth and Baker Hughes, one of the defendants in the Drill Bits Antitrust Litigation. ${ }^{508}$ Baker Hughes had brought suit against Rockbit for violating a patent agreement. While discovery was being conducted, Rockbit came across a memo from

508 David Ivanovich, Drill Bit Makers Face Charges of Conspiring to Fix Prices, HOUS. CHRON. (KRT) (Oct. 23, 1993) (Available in 1993 WLNR 3253623). 
Baker Hughes to a sales manager at Reed Tool Co. in Houston, which implicated the parties in a price fixing scheme. ${ }^{509}$

Rockbit then filed suit against Baker Hughes in November 1989 claiming the company violated federal antitrust laws by fixing prices, tying its products, and forcing Rockbit out of business in order to protect its price fixing conspiracy. ${ }^{510}$ Rockbit was not successful in this suit and a motion to dismiss was granted on June 24,1991 . The court found that Rockbit, as a manufacturer lacked the proper standing to bring the suit. ${ }^{511}$

This litigation prompted a Justice Department investigation and a private antitrust suit ("Drill Bits"). The DOJ conducted a investigation into the pricing practices of three of the major drill bit manufacturers named in the private action: Baker Hughes, Smith International d/b/a Reed Tool Company and Camco International. ${ }^{512}$ The government brought two different suits, one against Baker Hughes and one against Smith International and Camco International. Dresser

509 Id.

510 Rockbit Indus. U.S.A., Inc., V. Baker Hughes, Inc., 802 F.Supp. 1544, 1546-47 (S.D.Tex. 1991).

511 Id.

512 L.M. Sixe, Texas Firms Agree to Settle Price-Fixing Dispute, HOUS. CHRON. (KRT) (Sept. 10, 1993) (Available in 1993 WLNR 3254515). 
Industries, a defendant named in the private Drill Bits suit was not indicted.

The DOJ charged that between March and November 1989, Smith and Camco violated the Sherman Act. The two companies allegedly conspired to fix prices for roller cone drill bits by reducing discounts and by publishing new price lists. The government alleged that 500 customers - including independent drilling contractors, major oil companies and oil and gas property owners- were victimized by the price fixing. ${ }^{513}$ These cases resulted in criminal fines. ${ }^{514}$

In March 1991, a class action suit was brought on behalf of plaintiffs representing direct purchasers of roller cone drill bits. In their complaint plaintiffs allege that four drill bit manufacturers violated $\S 1$ of the Sherman Act. ${ }^{515}$ Between 1986 and 1992, plaintiffs allege defendants agreed to

513 David Ivanovich, Drill Bit Makers Face Charges of Conspiring to Fix Prices, HOUS. CHRON. (KRT) (Oct. 23, 1993) (Available in 1993 WLNR 3253623).

514 This investigation resulted in Baker Hughes pleading guilty and paying a one million dollar fine in 1992. In 1993, Smith International paid a fine of $\$ 675,000$ and Camco International settled charges filed against its Reed Division by promising to pay $\$ 575,000$.

Ralph Bivins, Houston Drill-Bit Price-Fixing Cases settled, HOUS. CHRON. (KRT) (Nov. 24, 1993) (Available in 1993 WLNR 3254369 ).

515 Complaint I $98-33$, Red Eagle Resources, et. al. V. Baker Hughes Inc., et al., No. 4:91cv00627 (Docket) (S.D.Tex. Mar. 11, 1991) (In re Drill Bits Antitrust Litigation). 
fix, stabilize, and/or inflate or raise the prices of drilling bits in the United States market by refraining from discounting their list prices and by refraining from competing among themselves on the basis of price. ${ }^{516}$ Several similar cases were consolidated into a class representing approximately 6,000 purchasers of drill bits. ${ }^{517}$

All Defendants settled over a three-year period for a total of $\$ 53.4$ million dollars. ${ }^{518}$ An attorney's fee of $30.8 \%$ or $\$ 16,129,271.00$ from the settlement funds was awarded to

516 Id. It was reported that defendants controlled approximately 75 percent of the domestic drill bit roller cone market at that time; Smith International dominated with a 27 percent share of the market, followed by Baker Hughes with 25 percent, Camco International with 15 percent and Dresser Industries with 12 percent. Ralph Bivins, Houston Drill-Bit Price-Fixing Cases Settled, HOUS. CHRON. (KRT) (Nov. 24, 1993) (Available in 1993 WLNR 3254369).

517 Ralph Bivins, Houston Drill-Bit Price-Fixing Cases Settled, HOUS. CHRON. (KRT) (Nov. 24, 1993) (Available in 1993 WLNR 3254369).

518 See Fine, Kaplan \& Black's website, at http://www.finekaplan.com/CustomPage.shtml\#1. Baker Hughes paid $\$ 17.8$ million in Jan. 1993, Reed Tool Company paid \$16.8 million and Camco paid $\$ 10.8$ million in september 1993. Dresser Industries was the last party to settle for \$8 million in April of 1994. Order of Approval of Settlement and Final Judgment, Doc. 372 (April 26, 1994), Red Eagle Resources, et. al. V. Baker Hughes Inc., et al., No. 4:91cv00627 (Docket) (S.D.Tex. Mar. 11, 1991) (In re Drill Bits Antitrust Litigation). 
class counsel in addition to reimbursement of expenses in the amount of $\$ 1,079,308.09 .519$

519 Order of Approval of Attorney's Fees and Expenses, Doc. 379 (April 26, 1994), Id. 
In re Relafen Antitrust Litigation, Civil Action No. 01-12239WGY; 346 F. Supp. 2d 349 (D. Mass. 2004); 231 F.R.D. 52 (D. Mass. 2005).

This case is noteworthy because: 1) Counsel for the direct purchaser Class secured a cash settlement of \$175 million, 69\% of their estimated class damages ${ }^{520}$ 2) Counsel for the indirect purchaser (end payer) class secured a cash settlement of $\$ 75$ million, $26 \%$ of their estimated damages; ${ }^{521}$ 3) The Defendant, UK-based GlaxoSmithKline Beecham Corporation ("GSK") took a $\$ 405$ million charge in the $4^{\text {th }}$ quarter of 2003 to provide for Relafen litigation, ${ }^{522}$ these settlements represent a large portion of that amount, much of which will be distributed among businesses based in the U.S; 4) Apparently there was no federal government investigation, although a state enforcer was permitted to intervene ${ }^{523}$; 5) The

520 Memorandum in Support of Direct Purchaser Class Plaintiff's Motion for Final Approval of Settlement, Document 290-01, filed 4/02/2002, In re Relafen Antitrust Litigation, Master File No. 01-12239-WGY at page 13 note 3. (D. Mass. 2004)

521 End Payer Plaintiffs' Memorandum of Law in Support of Final Approval of Proposed Settlement, Document No. 415, filed 4/25/2005, In re Relafen Antitrust Litigation, Master File No. 01-12239-WGY at page 3 (D. Mass. 2005).

522 GSK Settles Lawsuit Over Relafen Patent Tactic, Generic Line Copyright 2004 Washington Business Information, Inc., All Rights Reserved Generic Line, Vol. 21, No. 11, June 2, 2004.

523 On July 7, 2004, the states of Arkansas, Idaho, Illinois, Maryland, Oregon, and Washington filed motions to intervene in the end payer litigation already pending in the Massachusetts District Court, however, only Illinois was ultimately 
allegations involved violations under section 2 of the Sherman Act, and; 6) Plaintiffs' success in this litigation will discourage other brand name pharmaceutical manufacturers from manipulating the patent process and the Hatch-Waxman Act in a effort to unlawfully prevent generic competition, and keeping pharmaceutical drugs competitively priced is especially important because the cost of prescription drugs contributes greatly to the rising cost of healthcare.

On November 2, 1982 the United States Patent and Trademark Office ("PTO") denied GSK's sixth application to patent nabumetone, a non-steroidal anti-inflammatory drug. The PTO cited a 1973 article that described the method and synthesis of the drug, thus making any claim to nabumetone void for anticipation. On appeal, GSK persuaded the board of patent appeals that the substance and methods described in the 1973 article were distinguishable from the nabumetone GSK was trying to patent. On December 13, 1983 the PTO issued GSK a patent for nabumetone. The drug, which GSK marketed under the brand name Relafen, received FDA approval in February 1992.

In 1997 several generic drug manufacturers submitted Abbreviated New Drug Applications ("ANDA") to the FDA seeking

permitted to intervene. In re Relafen Antitrust Litigation, 231 F.R.D. 52, 61 (D. Mass. 2005). 
approval to begin marketing nabumetone. As part of their applications, each of the generic manufacturers ${ }^{524}$ certified that GSK's nabumetone patent was, to the best of their knowledge, invalid or unenforceable and gave GSK notice of their applications as is required by statute. GSK filed patent infringement actions against its would-be generic competitors, triggering an automatic stay of FDA approval for 30 months or until the patent litigation is resolved, pursuant to the Hatch-Waxman Act ${ }^{525}$. Generic versions of nabumetone would have otherwise been on the market on september 1, 1998.

524 The generic competitors included: Teva Pharmaceuticals USA, ("Teva") based in Israel, Copley Pharmaceutical, Inc., which was acquired by Teva in 1999; and Eon Labs, Inc., a division of Sandoz, Inc. ("Eon") which is headquartered in Princeton, New Jersey.

525 The complicated provisions of the Hatch-Waxman act provide the backdrop for this and similar litigation. Under its provisions, each ANDA must be accompanied by a certification that the drug for which they seek approval does not infringe on a legitimate patent right because the patent is either invalid, expired, or will not be infringed by the marketing of the generic drug. The patent holder is entitled to notice of this certification and, can immediately file a patent infringement suit against the generic competitor. Filing a patent infringement suit triggers an automatic stay of FDA approval of the generic manufacturer's ANDA for 30 months or until the patent litigation is resolved. 21 U.S.C. 355. Relevant provisions of the Hatch-Waxman Act were amended in 2003 See: The Medicare Prescription Drug, Improvement, and Modernization Act of 2003, Title XI: Access to Affordable Pharmaceuticals, sections $a-b$, United States Public Laws, $108^{\text {th }}$ Congress $-1^{\text {st }}$ Session, 108 P.L. 173 (2006). The amendments adopt several FTC recommendations, including that brand-name companies be limited to one 30-month stay of approval and that a counterclaim for improper Orange Book 
In August 2001, after a sixteen day bench trial, District Court Judge Reginald C. Lindsay declared GSK's nabumetone patent invalid due to anticipation. ${ }^{526}$ The Court also held that the patent was unenforceable due to inequitable conduct because GSK "engaged in a pattern of misrepresentation in its dealings with the PTO so pervasive as to negate any possibility that [its] misrepresentations to the PTO were inadvertent .... Such a pattern bespeaks only deliberate dissembling...." 527 Judge Lindsay's finding of invalidity was upheld on appeal, but the Federal Circuit Court did not reach the issue of unenforceability. ${ }^{528}$ Within a week of the District Court's decision, Teva Pharmaceuticals, USA ${ }^{529}$

listing be authorized for generic companies faced with patent infringement suits. Statement of the Honorable Timothy J. Muris before the Senate Judiciary Committee. Aug. 1, 2003. For a history of the act and a discussion of the recent amendments See: Elizabeth Stotland Weiswasser \& Scott D. Danzis, The Hatch-Waxman Act: History, Structure and Legacy, 71 Antitrust L.J. 585 (2003). For a discussion of the 2003 amendments and the loop holes that still exist see: Brian Porter, Comment: Stopping the Practice of Authorized Generics: Mylan's Effort to Close the Gaping Black Hole in the Hatch Waxman Act, $22 \mathrm{~J}$. Contemp. Health L. \& Pol'y 177 (Fall 2005).

526 In re 1639 Patent Litigation, 154 F.Supp. 2d 157. (Dist. Mass. 2001).

527 Id. at 194 .

528 GSK Beecham Cop. V. Copley Pharm., 45 Fed. Appx. 915, 917 (Fed. Cir. Aug 15, 2002) (unpublished opinion).

529 Teva Pharmaceuticals USA ("Teva") is a division of Teva Pharmaceuticals, which is based in Israel. 
("Teva") entered the market with a generic nabumetone priced at $60 \%$ of the Relafen price. ${ }^{530}$

Direct Purchasers of Relafen filed a consolidated class action complaint in December $2002^{531}$ and the District Court certified the Direct Purchaser Class on November 10, $2003 .{ }^{532}$

530 Affidavit of Co-Lead Counsel Bruce E. Gerstein and Linda P. Nussbaum, Document 295-01, filed 4/02/2002, In re Relafen Antitrust Litigation, Master File No. 01-122390WGY at page 7 paragraph 14. (D. Mass. 2004).

531 In addition to the Direct Purchaser Class, actions were filed by GSK's competitors, Teva Pharmaceuticals USA Inc. ("Teva"), and Eon Labs, Inc. ("Eon") Eon Labs., Inc. V. SmithKline Beecham Corp., Civ. A. No. 03-10506-WGY, Doc. No. 62 ; and by drugstore Plaintiffs see note 12, infra. The website for the National Association of Attorneys General (www.naap.org) reports that in 2004 West Virginia was the lead state in litigation initiated in 2004 against GSK with the help of the U.S. Department of Justice. The litigation was regarding GSK's efforts to block generic competition with Relafen and two other drugs, Paxil and Augmentin. This case settled for $\$ 500,000$ dollars plus attorney's fees. West Virigina ex rel. MCGraw V. GlaxoSmithkline, PLC et al. 04-C254M, Circuit Court of Marshall County 2005). (Summary available at: www.naap.org).

532 In re Relafen Antitrust Litigation, 218 F.R.D. 337 (D.Mass. 2003). The Direct Purchaser Class included all entities in the U.S. who purchased Relafen directly from defendants between September 1, 1998 and December 31, 2002.. Drugstore Plaintiffs (Albertson's, Eckerd, Hy-Vee, Kroger, Walgreens, CVS, Rite Aid, and Safeway opt-ed out of the class and chose to pursue individual actions) filed complaints against SmithKline on March 29, 2002 and January 7, 2003 asserting claims under sections 15 and 26 of the Sherman Act. Walgreen co. V. SmithKline Beecham Corp., Civ. A No. 02-10588-WGY, Doc. No. 1, CVS Meridian, Inc. v. SmithKline Beecham Corp., Civ. A. No. 03-10040-WGY, Doc. No. 1. These plaintiffs settled with SmithKline and the action was closed on January 20, 2004, 
The Plaintiffs alleged that the nabumetone patent was fraudulently obtained and wrongfully listed in the FDA's Orange Book, ${ }^{53}$ and that the patent infringement suits that GSK filed against its generic competitors were baseless sham litigation used to delay competition with Relafen. Plaintiffs alleged that this conduct violated section 2 of the Sherman Act causing class members to pay substantially higher prices for nabumetone than they would have if generic entry to the market had not been wrongfully delayed.

Class counsel spent an aggregate of over 33,700 hours litigating this case over the course of two years, taking more than 30 depositions and reviewing hundreds of thousands of internal company documents during the course of discovery. Counsel succeeded in persuading the court that Defendants should be collaterally estopped from relitigating key issues that were decided in the underlying patent litigation and defeated GSK's motion to dismiss and motion for summary judgment.

The Direct Purchaser Class reached a settlement agreement January 9, 2004, on the eve of trial, for $\$ 175$

Walgreen, Civ. A. No. 02-10588-WGY, DoC. No.11, CVS Meridian, Civ. A. No. 03-10040-WGY, Doc. No.11.

533 The "Orange Book: is an official FDA publication formally know as "Approved Drug Products with Therapeutic Equivalence Evaluations." 
million dollars. Not a single member of the class objected to the terms of the settlement, which is especially significant in light of the fact that this class consists of large, sophisticated businesses, many of whom are independently represented and could be expected to object. ${ }^{534}$ The court subsequently approved the settlement and granted Class Counsel's request for one-third of the fund in attorney's fees plus $\$ 1,799,023.24$ in expenses, and a $\$ 25,000$ incentive award for named plaintiff Louisiana Wholesale Drug Co., Inc. Judge William G. Young for the District of Massachusetts noted that the award was "fair in this case" 535 given "that Class Counsel vigorously and effectively pursued the Class members' claims." 536 The $\$ 175$ million dollar cash settlement represents a substantial percentage --approximately $69 \%--$ of plaintiffs' total damages according to plaintiff's expert's estimate that class-wide damages totaled $\$ 252.8$ million.

The first indirect purchaser (end payer) action was filed on January 30, 2002 and the District Court certified a

534 Memorandum in Support of Direct Purchaser Class Plaintiff's Motion for Final Approval of settlement, Document 290-01, filed 4/02/2002, In re Relafen Antitrust Litigation, Master File No. 01-122390WGY at page 18. (D. Mass. 2004).

535 T.R.O. Hrg. Transcr. 4:3-4 (April 9, 2004) In re Relafen Antitrust Litigation, 346 F.Supp. 349.

536 In re Relafen Antitrust Litigation, 2004 U.S. Dist. LEXIS 28801 at 19 (D. Mass. 2004). 
nationwide class for purposes of settlement on September 28, 2005. ${ }^{537}$ The class represented actual and potential third party payers and consumers of both Relafen and its generic alternatives including individual consumers, health care plans and insurers. Plaintiffs asserted claims under federal and state antitrust laws, state unfair competition and consumer protection statutes, and the unjust enrichment doctrines of 24 states. ${ }^{538}$ Similar to the Direct Purchaser Class, the End Payer's alleged that GSK made misrepresentations in pursuit of a patent for nabumetone which ultimately resulted in substantially higher prices for both Relafen and its generic alternatives.

Class counsel spent four years and more than 29,000 hours litigating this case including analyzing more than one million pages of documents and taking more than 75 depositions during discovery. Counsel successfully opposed a motion to dismiss and succeeded in defeating GSK's motion for summary judgment.

The End Payer Class reached a settlement agreement on November 18,2004 for $\$ 75$ million. The settlement also included a Cy Pres award of $\$ 500,000$ for consumers and third party payers whose claims were limited for procedural

537 In re Relafen Antitrust Litigation, 231 F.R.D. at 57. 538 Id. at 60 . 
reasons. ${ }^{539}$ There were no objections to the amount of the settlement, and in fact the court noted that "[t] he overall reaction to the settlement has been positive," which is significant given the 272,229 class members. ${ }^{540}$ The court approved the settlement on september 28, 2005 and granted counsel's request for one-third of the fund ${ }^{541}$ in attorneys' fees, plus $\$ 1,297,301.10$ in expenses, and incentive awards. ${ }^{542}$ In approving the final settlement Judge Young commented on "the exceptional efforts of class counsel" and had previously noted that the proposed settlement was "the result of a great deal of fine lawyering on behalf of the parties. . . ."543 According to the End Payer's expert the \$75 million settlement

539 Id. at 82 .

540 Id. at 64,72 . The settlement was divided between consumers and third-party payers, with one third going to reimburse consumers and the remainder to third-party payers.

541 Id. at $77 \mathrm{n} .18$. Because a portion of the $\$ 75$ million settlement fund was paid to settling health plans as part of a separate agreement with GSK, the award of attorney's fees and expenses is based on the $\$ 67$ million of the fund that remains.

542 Incentive awards included "\$8,000 for each named consumer Plaintiff, \$9,000 for each named consumer organization, and \$14,000 for each named third party payor." Id. at 82 .

543 Id. at 80 . 
represents $26 \%$ of the estimated $\$ 294$ million in class

damages. ${ }^{544}$

Most significant is the deterrent effect that the large settlements in these cases will have on other brand name drug manufacturers seeking to fraudulently obtain or extend patents in an effort to charge monopoly prices for prescription drugs.

544 End Payor Plaintiffs' Memorandum of Law in Support of Final Approval of Proposed Settlement, Document No. 415, filed 4/25/2005, In re Relafen Antitrust Litigation, Master File No. 01-12239-WGY at page 3 (D. Mass. 2005). 
In re: Remeron Antitrust Litigation, 2005 U.S. Dist. Lexis 27013 (D.N.J. 2005).

This case is noteworthy because: 1) It highlights loopholes in the Hatch-Waxman Act ${ }^{545}$ being used to forestall generic competition; 2) Counsel for the Direct Purchaser Class persevered after an early setback and after all other plaintiff classes settled, and secured a \$75 million settlement which represents 56-69\% of Plaintiffs' estimate of the overcharges paid as a result of Defendant, Organon Inc.'s ${ }^{546}$ ("Organon") anticompetitive scheme; 3 ) Private counsel was first to investigate the conduct at issue, and obtained most of the relief in this matter because the federal

545 Relevant provisions of the Hatch-Waxman Act were amended in 2003. See: The Medicare Prescription Drug, Improvement, and Modernization Act of 2003, Title XI: Access to Affordable Pharmaceuticals, sections a-b, United States Public Laws, $108^{\text {th }}$ Congress $-1^{\text {st }}$ Session, 108 P.L. 173 (2006). The amendments adopt several FTC recommendations, including that brand-name companies be limited to one 30-month stay of approval and that a counterclaim for improper Orange Book listing be authorized for generic companies faced with patent infringement suits. Statement of the Honorable Timothy $j$. Muris before the Senate Judiciary Committee. Aug. 1, 2003. For a history of the act and a discussion of the recent amendments See: Elizabeth Stotland Weiswasser \& Scott D. Danzis, The Hatch-Waxman Act: History, Structure and Legacy, 71 Antitrust L.J. 585 (2003). For a discussion of the 2003 amendments and the loop holes that still exist see: Brian Porter, Comment: Stopping the Practice of Authorized Generics: Mylan's Effort to Close the Gaping Black Hole in the Hatch Waxman Act, $22 \mathrm{~J}$. contemp. Health L. \& Pol'y 177 (Fall 2005).

546 Organon Inc., now Organon USA, is a division of Dutch pharmaceutical giant Akzo Nobel, NV. 
government permanently closed its investigation prior to securing any relief; ${ }^{547}$ and 4) Judge Hochberg, who approved the settlement on November 9, 2005, awarded class counsel their request of one-third of the recovery in attorneys' fees and thanked counsel on behalf of the entire federal judiciary "for the kind of lawyering we wish everybody would do." ${ }^{548}$

547 The Federal Trade Commission (FTC) announced its decision to close its investigation in a press release on Oct. 20, 2004 noting that "significant evidence indicate[s] that Organon may have violated Section 5 of the Federal Trade Commission Act by knowingly making misleading statements to the FDA in order to delay introduction of generic competition to Remeron." Statement of the Federal Trade Commission Regarding the Decision to Close Its Investigation into the Conduct of Akzo Nobel, NV and Its Organon Subsidiary (available at Federal Trade Commission, For the Consumer, http: //www.ftc.gov/opa/2004/10/organon.htm (last updated October 13, 2006)). Before closing its investigation, however, the FTC worked with state attorney general to incorporate injunctive terms into the End-Payer's proposed settlement. In Re: Remeron End-Payer Antitrust Litigation, 2005 U.S. Dist. LEXIS 27011 (D.N.J. 2005).

548 In Re Remeron Antitrust Litigation, Civil Action no. 022007 (FSH) (D.N.J. 2005) (Transcript of proceedings at 15:16). 
In 2003, direct purchasers ${ }^{549}$ of Remeron filed class action complaints against Organon alleging various illegal and deceptive means to improperly obtain and extend patents for the drug mirtazapine ${ }^{50}$ in violation of Section 2 of the Sherman Act. Remeron received FDA approval in 1996 and Organon's right to market exclusivity was set to expire in June 2001. In 1999 Organon obtained a patent for a mirtazapine combination drug which it listed in the FDA's Orange Book ${ }^{551}$ in January 2001. Because mirtazapine was listed in the Orange Book, generic drug manufacturers intending to market mirtazapine were required under the Hatch-Waxman Act to provide notice to Organon as part of their Abbreviated New Drug Application ("ANDA") filed with the FDA. 552 After

\footnotetext{
549 Nine large chain stores opted out of the direct purchaser class and settled for a total of $\$ 59.8$ million in 2004 . Technology \& Health Brief Akzo Nobel NV: Remeron Antitrust Suit Settled In the U.S. for \$59.8 Million, The Wall Street Journal, Oct. 4, 2004. End-payers, including attorney generals for Texas, Florida and Oregon, filed a Consolidated Class Action Complaint in September 2002 and settled for $\$ 36$ million in 2004. In Re: Remeron End-Payer Antitrust Litigation, 2005 U.S. Dist. LEXIS 27011 (D.N.J. 2005). Organon settled with competitor, Mylan laboratories Inc, for \$15 million. Dow Jones Newswires, Business Brief -Mylan Laboratoires Inc.: Akzo Nobel Pays \$15 Million in Depression-Drug Settlement, The Wall Street Journal, pg B2 Oct. 4, 2004.
}

550 Organon holds a patent on mirtazapine, an antidepressant drug, which it manufactures and markets under the brand name Remeron.

551 The "Orange Book" is an official FDA publication formally known as "Approved Drug Products with Therapeutic Equivalence Evaluations."

552 Each ANDA must be accompanied by a certification that the drug for which approval is sought does not infringe on a 
receiving notice, Organon filed patent infringement suits ${ }^{553}$ against the would-be generic competitors triggering a stay of FDA approval of the generic competitors' ANDA's for 30 months or until a final judgment in the patent infringement suits.

The litigation was complex and hard fought. The district court granted Defendant's motion to dismiss the generic manufacturers' antitrust counter-claims alleging sham litigation, holding that the court could not find that Organon lacked an objectively reasonable basis for its patent infringement claims. ${ }^{554}$ The court later held that the Direct Purchaser Class was collaterally estopped from litigating its similar claims. However, the court upheld the independent claims arising from Defendants' late-listing in the Orange Book of the newly-patented combination drug and the

legitimate patent right because the patent is either invalid, expired, or will not be infringed by the marketing of the generic drug. The patent holder is entitled to notice of this certification and, can immediately file a patent infringement suit against the generic competitor. Filing a patent infringement suit triggers an automatic stay of FDA approval of the generic manufacturer's ANDA for 30 months or until the patent litigation is resolved. 21 U.S.C. 355. Relevant provisions of the Hatch-Waxman Act were amended in 2003. See supra note1.

553 The Direct Purchaser Class' complaint came on the heels of a December 2002 grant of summary judgment in favor of certain generic competitors with respect to the patent infringement suits filed by Organon. In Re Remeron End-Payer Antitrust Litigation, 2005 U.S. Dist. LEXIS 27011 at 4, (D.N.J. 2005).

554 Organon, Inc. V. Mylan Pharmaceuticals, Inc., 293 F.Supp. 2d 453 (D.N.J. 2003). 
Defendant's alleged overarching scheme to forestall generic competition. Although every other plaintiff group involved in the litigation chose to settle their claims after this early set back, the Direct Purchaser Class persevered and sought recovery for the harm wrought by Defendants' attempts to prevent and delay generic competition in the mirtazapine market .

Class Counsel aggressively pursued the surviving claims, filing motions for summary judgment, partial summary judgment and issue preclusion. Class counsel invested an aggregate of more than 35,000 hours on this complex litigation involving research and analysis of a variety of issues including regulatory requirements of the Hatch-Waxman Act and FDA's Orange Book listing, the intricacies of the pharmaceutical industry from scientific and production processes to sales and marketing, as well as patent law and economic issues. The contentious discovery process produced more than one million pages of documents and class counsel conducted more than 45 depositions and spent thousands of hours researching, analyzing and consulting with experts. These efforts led to vital evidence indicating, among other things, that Defendants knew their listing of the combination drug in the FDA's Orange Book was improper and was undertaken with the express intent of delaying generic competition. After more than two years of 
negotiation and numerous mediation sessions, the parties agreed to settle for $\$ 75$ million to be distributed pro-rata among the direct purchaser class after the deduction of onethird in attorneys' fees plus expenses. The \$75 million settlement represents a significant proportion - 56-69\% - of the class damages as estimated by the Direct Purchasers' expert. ${ }^{555}$

At the hearing on the motion for final approval of settlement, District of New Jersey Judge Faith S. Hochberg thanked counsel on behalf of the entire federal judiciary "for the kind of lawyering we wish everybody would do"556 and noted that "[t]he settlement entered with Defendants is a reflection of Class Counsel's skill and experience." ${ }^{557}$ Judge Hochberg approved the settlement and plan of allocation, and granted Class Counsel's request for one-third in attorneys' fees plus expenses and an incentive award on November 9, 2005.

555 Memorandum of Law in Support of Direct Purchaser Class Plaintiff's Motion for an Award of Attorneys' Fees, Reimbursement of Expenses, and Incentive Award, filed 10/26/2005, In re Remeron Antitrust Litigation, Master Docket No. $03-C V-0085$ (D.N.J. 2005)

556 In Re Remeron Antitrust Litigation, Civil Action no. 022007 (FSH) (D.N.J. 2005) (Transcript of proceedings at 15:16)

557 In re Remeron, (2005 U.S. Dist. LEXIS 27013) [Not for Publication] (D.N.J. 2005). 
In Re Rubber Chemicals Antitrust Litigation, 350 F.Supp.2d 1366, 2005-1 Trade Cases P 74,804 (Jud.Pan.Mult.Lit. Dec. 21, 2004 ( (No. MDL 1648).

Summary: These related cases concern an agreement between three of the largest manufacturers of rubber chemicals in the world to artificially fix prices in the sale of rubber chemicals and to allocate markets and customers in the United States. They are noteworthy because: 1) Counsel for the direct purchaser class secured a settlement of over \$268 million dollars, all of which came from foreign corporations and their American affiliates; 2) Counsel in the direct purchaser class was awarded a fee of twenty-five percent (25\%); and 3 ) Counsel secured an \$18 million settlement with a defendant which was not indicted in the parallel government investigation, Akzo/Flexsys corporations and their affiliates.

This case initially started on or about september 26 , 2002, with a series of government raids on a number of rubber chemical producers, including Bayer AG and Flexsys NV, in several European cities. These unannounced inspections were in connection with an investigation into the alleged cartel 
agreement and related illegal practices concerning the pricefixing of rubber chemicals. ${ }^{558}$

As a result of this investigation, a number of companies and their top executives plead guilty, paid criminal fines and served jail time starting in 2004. Crompton and two of its top executives plead guilty to price fixing in the international rubber chemicals market, ${ }^{559}$ after admitting to "participating in a combination and conspiracy to suppress and eliminate competition by maintaining and increasing the price of certain rubber chemicals" sold in the United States from 1995-2001. ${ }^{560}$ Bayer AG agreed to plead guilty and pay a \$66 million fine for participating in the conspiracy. ${ }^{561} \mathrm{~A}$ number of its top

558 Second Amend. Consol. Compl. for Violations of the Fed. Antitrust Laws I 51 (Mar. 18, 2005).

559 Crompton was sentenced to pay a \$50 million criminal fine and its executives await sentencing. Press release, U.S. Dept. of Justice (Sept. 14, 2004), First Executive in the International Rubber Chemicals Cartel Agrees to Plead Guilty, available at http://searchjustice.usdoj.gov/search?q=cache: 6MwGZC767v0J : www .usdoj.gov/atr/public/press releases/2004/205419.wpd; see also Press Release, U.S. Dept. of Justice (Sept. 21, 2004) Executive in the International Rubber Chemicals Cartel Agrees to Plead Guilty. Available at http://searchjustice.usdoj.gov/search?q=cache: 8 VCoA3b1s8J:Www .usdoj.gov/atr/public/press_releases/2004/205496.wpd.

560 Id.

561 Press Release, U.S. Depart. Of Justice (July 14, 2004 ). Bayer Agrees to Plead Guilty and Pay \$66 Million Fine for Participating in Rubber Chemicals Cartel. Investigation to 
executives were sentenced to fines and imprisonment. ${ }^{562}$ Flexsys NV was not a target of the DOJ investigation. ${ }^{563}$

On April 8, 2003, the first private complaint in this multi-district litigation was filed. Several subsequentlyfiled cases were consolidated and a Second Amended Consolidated Complaint for violations of federal antitrust laws was filed on March 18, 2005 in the United States District Court Northern District of California. Direct purchasers of Rubber chemicals, including the companies and industrial manufacturers, brought this lawsuit alleging that from at least as early as May 1, 1995 through December 31, 2001,

Date Yields Over $\$ 100$ Million in Criminal Fines. Available at http://www.usdoj.gov/opa/pr/2004/July/04_at_480.htm.

562 On November 23, 2004, Martin Petersen, a German national and Head of Marketing and Sales for Bayer's Rubber Business Group agreed to plead guilty. He was sentenced to four months in jail and a $\$ 50,000.00$ fine. Available at http://www.usdoj.gov/atr/public/speeches/215514a.htm\#a. On May 16, 2005, Wolfgang Koch, a German national of Bayer plead guilty and was sentenced to four months in jail and a $\$ 50,000$ fine. Press Release, U.S. Dept. of Justice (May 16, 2005) Former Bayer $A G$ Executive Agrees to Plead Guilty in International Rubber Chemicals Price-Fixing Conspiracy. Former Executive Faces Jail Time in U.S. Available at http://usdoj.gov/atr/public/press_releases/2005/209038.wpd. On August 10, 2005 Jurgen Ick and Gunter Monn, top executives at Bayer, were indicted. Both Ick and Monn are German citizens and remain international fugitives. Press release, U.S. Dept. of Justice (Aug. 10, 2005) Former Top Bayer Executives Indicted in Price-Fixing Conspiracy. Available at http://searchjustice.usdoj.gov/search?q=cache: Tkx6stpvMn0J : www .usdoj.gov/atr/public/press_releases/2005/210540.wpd.

563 Id. 
Defendants conspired to fix the prices of Rubber Chemicals sold in the United States and/or to allocate markets and/or customers in the United States. ${ }^{564}$

In 2005 Plaintiffs settled with two of the three groups of defendants for approximately $\$ 268$ million: ${ }^{565}$ Bayer, and its affiliates in Germany, Pennsylvania, Ohio and New Jersey ${ }^{566}$; and Akzo/Flexsys and its affiliates in the Netherlands, Illinois, Belgium and Ohio. ${ }^{567}$ The case against Crompton appears to be ongoing.

In the course of this litigation class counsel analyzed hundreds and thousands of documents produced by Defendants. ${ }^{568}$ They also conducted an independent investigation of the facts and analyzed Defendants' sales and pricing data. Class counsel was awarded an attorney's fee equal to 25\% of the Flexsys

564 Second Amend. Consol. Compl. for Violations of the Fed. Antitrust Laws If 2 (Mar. 18, 2005).

565 Flexsys paid $\$ 18,500,000$. Settlement Agreement of Defendants Flexsys N.V. and Flexsys America L.P., and Akzo Nobel Chemicals International B.V. and Akzo Nobel Chemicals, Inc. ("Flexsys Defendants"), Doc. 12 (Feb. 18, 2005), 凤 7. Bayer settled for $\$ 250,375,190$. Notice of settle. in Class Action and Hearing on Settle. Approv., Plan of Allocation and Request for Atty's Fees and Costs (June 26, 2006), \ 17.

566 Id. \\ $18-21$

567 Id. \\13-17.

568 Id. 913. 
Settlement Fund, or $\$ 4,625,000$ (and $\$ 692,523.57$ for costs). ${ }^{569}$ Counsel was awarded approximately $20 \%$ of the Bayer settlement Fund, or $\$ 47,975.19$ and also $\$ 400,000$ for costs. ${ }^{570}$

569 Order Granting Interim Atty's Fees and Reimburse. Offof Costs to Class Counsel Based on the Settlement with the Flexsys Defendants, Doc. 150, (June 21, 2005), I 1.

570 Notice of Settle. in Class Action and Hearing on settle. Approv., Plan of Allocation and Request for Atty's Fees and Costs (June 26, 2006), I 17 . 
In re Sorbates Direct Purchaser Antitrust Litigation, Not Reported in F.Supp.2d, 2002 WL 31655191 (N.D. Cal.).

This case is noteworthy because: 1. the primary defendants/manufacturers, who formed a price fixing cartel between 1979 and 1996, were spread out between three countries (United States, Germany, and four in Japan) and defended their actions globally (United States, Canada, and Europe), making this litigation a complex and extensive process; 2 . civil actions were brought by both direct purchasers of sorbates and on behalf of indirect purchasers of many states within the U.S.; 3 . total recovery for direct purchasers in the U.S. was roughly $\$ 96.5$ million (at least $\$ 36.5$ million of which came from foreign defendants) ${ }^{571} ; 4$. attorneys fees varied between the direct purchaser and state actions from 22$33 \%$ of the total recovery.

In 1998 the U.S.D.O.J. began an investigation into the alleged price fixing of sorbates, a chemical manufactured for use in the food preservatives industry, by several large multinational corporations. The Dept. of Justice investigated Eastman Chemical, Co. (U.S. manufacturer), Hoescht AG, Nutrinova Nutrition Specialties \& Food Ingredients GmbH, CNA Holdings (German manufacturer), and Daicel Chemicals Industry,

571 In addition, several actions, brought by individual states on behalf of indirect purchasers, settled for a total of more than \$12 million. 
Ltd., Nippon Synthetic Chemical Industry Co., Ltd., Ueno Fine Chemicals Industry Ltd., and Chisso Corporation (the four Japanese manufacturers) to determine whether they had formed a cartel for the purpose of fixing the prices of sorbates between 1979 and $1996 .{ }^{572}$

In response to the DOJ investigation, several of the industries "[pled] guilty to participating in the antitrust conspiracy to suppress and eliminate competition by fixing prices and allocating the market shares of sorbates sold in the United States." ${ }^{573}$ Following this, the European Commission held similar investigations which resulted in additional criminal fines. 574 The Commission found that by 1995, the

572 Williams Food Inc. V. Eastman Chem. Co., Not Reported in P.3d, 2001 WL 1298887 (Kan. Dist. Ct.).

573 Id. Between 1998 and 2001, Diacel, Hoescht, Nippon, Eastman and Ueno, agreed to pay fines of \$53 million, \$36 million, \$21 million, \$11 million, and \$11 million, respectively, as a result of litigation with the Department of Justice. U.S. Department of Justice, Antitrust Division, Sherman Act Violations Yielding a Fine of \$10 Million or More (January 23, 2003), at http://www.usdoj.gov/atr/public/criminal.htm.

574 These fines totaled EUR \$172 million; divided between Hoescht (\$123 million), Diacel (\$20.6 million), Ueno (\$15.3 million) and Nippon (\$13.1 million). Chemicals: Monti's Cartel Clampdown: Sorbates Firms Fined EUR 138 M: Hoescht, Chisso, Daicel Chemical Industries, Nippon Synthetic Chemical Idustry and Ueno Fine Chemicals, Chemical Business NewsBase - Europe Environment, October 9, 2003. "The Commission calculated the fines according to the gravity and duration of the infringement, but took into account the level of cooperation from the companies." Chisso Corp. was granted full immunity for its role as a whistleblower. Id. 
cartel had control of $85 \%$ of the sorbates market in Europe. ${ }^{575}$ Additionally, Hoescht $A G$ and Eastman Chemicals both pled guilty to violations of the Competition Act of Canada. ${ }^{576}$

In addition to the fines, several civil actions were brought in the U.S. by both direct purchasers represented by private counsel, and by states on behalf of classes of indirect purchasers within those states. The direct purchasers led the way with a consolidated class action in the Northern District of California; followed by a few separate smaller classes of direct purchasers in other states. Finally cases brought by states had varied success in different state courts throughout the country.

A large group of direct purchasers brought suit in the Northern District of California, which resulted in final approval of a settlement for $\$ 81,978,000 i^{577}$ followed shortly

575 Id.

576 They were fined a total of $\$ 3.28$ (Canadian) in a Canadian federal court Companies Guilty of Price Fixing, The Toronto Star October 27, 1999, Wednesday, Edition.

577 In re Sorbates, Master File C 98-4886 Cal (N.D. Cal. 2000) (combined settlement of Diacel, Nippon, Hoescht and Eastman). "Japan's Daicel Chemical Industries Ltd. and Nippon Synthetic Chemical Industry Co. revealed in separate statements that they would pay $\$ 16$ million and $\$ 7.2$ million, respectively to US food firms." CHEMICAL COMPANIES: Japanese Firms To settle Antitrust suit For $\$ 23.2 \mathrm{M}$, Wednesday, Dec. 12, 2001, Vol. 3, No. 242, at http://bankrupt.com/CAR_Public/011212.mbx. 
by a second settlement for $\$ 14.6$ million. ${ }^{578}$ At least $1 / 3$ of direct purchaser recovery, which covered the vast majority of private civil recovery, came from foreign defendants. ${ }^{579}$ Defendants were required to make yearly contributions into a net settlement fund, where purchasers could recover damages measured by a mathematical formula approved by the court. Successful suits by states on behalf of indirect purchasers were brought in Wisconsin, California, Kansas, Ohio and Illinois, totaling over $\$ 12$ million. ${ }^{580}$ Notably, the Wisconsin suit was brought on behalf of purchasers in 12

578 In re Sorbates Direct Purchaser Antitrust Litigation, Not Reported in F.Supp.2d, WL 31655191 (N.D. Cal. 2002). With $\$ 6.5$ million being allocated to Euno. EUNO FINE CHEMICALS: Judge Approves \$6.5M Settlement Deal, Thursday, November 28, 2002, Vol. 4, No. 235, http://bankrupt.com/CAR_Public/021128.mbx

579 See supra notes $7 \& 8$. The remaining $2 / 3$, totaling over $\$ 60$ million was divided b/w Hoescht (a german corporation), Eastman (an American corporation) and one other. FOOD FIRMS: Freeman, Freeman Files Sorbate Price-Fixing Suit, Thursday, July 27, 2000, Vol. 2, No. 145, http://bankrupt.com/CAR_Public/ $000727 . \mathrm{MBX}$.

580 EASTMAN CHEMICAL: Indicates Openness to settle Remaining Sorbates Cases, Tuesday, May 15, 2001, Vol. 3, No. 95, http://bankrupt.com/CAR_Public/010515.mbx; Sorbates Prices Cases, JCCP NO. 4073 (Sup. Ct. Cal. 2003) http://www.sorbatessettlement.com/not.html; Williams Food V. Eastman Chemical, Not Reported in P.3d, 2001 WL 1298887 (Kan.Dist.Ct. 2001); State v. Diacel Chemical Ind., No. $02 \mathrm{CH} 19575$ (Illinois 2004); Children's Hunger Alliance Receives \$197,761 from Sorbates Settlement, 2005 http://www. childrenshungeralliance.org/NEWS/0406/0406-ag.html 
states and constituted a large bulk of non-direct purchaser recovery with a settlement of $\$ 7.8$ million. ${ }^{581}$

Attorneys fees and costs awarded have varied between jurisdictions and plaintiff classes. The percentages were between $22 \%$ and $33 \%$ of total recovery. ${ }^{582}$

581 Of those state's that have recovered, there is a general trend toward cy pres distribution of the funds. For instance, several states have donated large portions of their settlements to food banks, boys and girls clubs, and other charitable local institutions PRESERVATIVE MAKERS: Judge Approves Settlement of Wisconsin Suit, Monday, April 30, 2001, Vol. 3, No. 84 http://bankrupt.com/CAR_Public/010430.mbx.

582 See id. (direct purchaser settlement of Euno and Chisso at 25\%); Proposed Final Judgment and Order, State V. Daicel Chem. Ind., et.al. (No. 02CH19575) at http://www.illinoisattorneygeneral.gov/consumers/sorbates/prop osed_final_judgment\&order.pdf (Illinois settlement at 22.5\%); Williams Food Inc. V. Eastman, et. al., 2001 WL 1298887 (Kan. Dist. Ct.) (opt out Kansas direct purchaser litigation at 33 $1 / 3 \%$ ). 
Sun Microsystems V. Microsoft, 333 F.3d 517 (4 ${ }^{\text {th }}$ Cir. 2003).

This case is notable because 1 . It involved an exceptionally large payment for the settlement of an antitrust claim, \$700 million out of a \$2 billion overall payment by Microsoft to Sun; 2. While the action relied in part upon findings of fact and conclusions of law made in the U.S. Government's Microsoft case, its allegations were much broader then those in the government's case; 3 . Sun provided much of the evidence that it accumulated for this case to the European Union, and this evidence apparently helped form much of the basis for its action against Microsoft involving the server market; 3 . The allegations involved rule of reason violations, not "hard core" cartel violations; 4. The agreed-upon relief helped protect Java from pollution by Microsoft, and helped ensure that only pure, non-Microsoft Java would in the future be distributed on PCs. This was a significant victory for the PC ecosystem and the consumers who benefit from it.

In March 2002 sun filed an antitrust suit against Microsoft, charging that Microsoft had engaged in a number of antitrust violations, some of which mirrored the charges in the U.S. government's case against them, and others of which were broader. Sun also charged a number of intellectual 
property violations. Among the specific antitrust violations were the allegations that Microsoft illegally attempted to monopolize the Intel-compatible PC operating systems market, the browser market, and the office suite market. Sun also charged Microsoft with attempting to monopolize the workgroup server market. In addition, sun charged Microsoft with illegally tying Internet Explorer to its PC operating system, its workgroup server to its PC operating systems, and its exchange server software to its office productivity suites. Sun also charged that Microsoft illegally entered into exclusive dealing arrangements for its browser, and that it entered into exclusionary agreements with Apple and Intel not to develop, distribute or use non- Microsoft compatible implementations of Sun's Java platform, in violation of Section 1 of the Sherman Act.

On January 21, 2003, the United States District Court for the District of Maryland granted Sun's motion for preliminary injunction. ${ }^{583}$ Microsoft was, inter alia, enjoined from distributing its Windows PC Operating System or Browser unless they contained unpolluted Java software.

Microsoft appealed this decision, however, and the $4^{\text {th }}$ Circuit lifted the preliminary injunction. The reasons for this reversal were that: "(1) future and present harm alleged

583 Sun V. Microsoft, 240 F. Supp. 2d 460 (D. Md. 2003). 
by competitor were insufficient to support mandatory preliminary injunction requiring manufacturer to distribute competitor's middleware software with every copy of manufacturer's operating system and web browser; [and that the] (2) mandatory preliminary injunction was not necessary to prosecute competitor's claim that manufacturer had monopolized operating system market..." The Court of Appeals remanded the case for a trial on the merits.

On April 2, 2004, Sun and Microsoft agreed to settle these antitrust and intellectual property issues, and also agreed on a variety of patent license and other issues. Of the overall $\$ 2$ billion settlement, a joint sun-Microsoft Press Release attributed $\$ 700$ million to a settlement of Sun's antitrust claims against Microsoft. ${ }^{584}$

584 See April 2, 2004 Press Release, "Microsoft and Sun Microsystems Enter Broad Cooperation agreement; Settle Outstanding Litigation" available at http:www. sun.com/smi/Press/sunflash/2004-04. 
In Re: Terazosin Hydrochloride Antitrust Litigation Case No. 99-MDL-1317-Seitz/Klein, a/k/a Louisiana Wholesale Drug Co., Inc. v. Abbot Laboratories, et al. S.D. Fla. Case no. 98-3125 and Valley Drug Co. v. Abbot Laboratories, et al. S.D. Fla. Case No. 99-7143.

Summary: This case is noteworthy because: 1) Although the government was first to investigate, the litigation was primarily initiated and led by private counsel; ${ }^{585}$ 2) Private counsel obtained a substantial monetary recovery, whereas the federal government secured only injunctive relief; ${ }^{586}$ 3)

585 The first federal government action in this case was the complaint and consent order proposal issued by the Federal Trade Commission (FTC) on March 16, 2000, more than one year after the first Direct Purchaser complaint was filed in December 1998. Attorney Generals for Colorado, Kansas and Florida filed suit alleging antitrust violations based on the same facts on september 27, 2001 "on the heels of an investigation started [in 1999] by the Federal Trade Commission." Michael Perrault, Suit: Drug Makers Were In Collusion, Rocky Mountain News, Pg. 4B, September 28, 2001.

In many cases the Attorneys General or the FTC will conduct a non-public investigation before filing a complaint, making it difficult to determine whether the government or private counsel began investigating first, or were conducting separate, parallel investigations.

586 The FTC finalized a consent order against Abbott and Geneva on May 22, 2000. In the Matter of Geneva Pharmaceuticals, Inc., Docket No. C-3946, Decision and Order (available at Federal Trade Commission, Bureau of Competition: Case Filings, http://ftc.gov/os/2000/05/c3946.do.htm (last updated December 14, 2001)). The order, which terminates on May 22, 2010, prohibits both companies from entering into any further similar agreements and requires that Geneva report to the FTC annually for five years on the manner and form of its compliance. Despite the range of remedies available to the government, "including possibly seeking disgorgement of illegally obtained profits," the order was the only relief 
Counsel for the Plaintiffs' class were successful in

persuading the District Court that the agreement between Abbot Laboratories"587 ("Abbott") and its generic competitor, Geneva Pharmaceuticals, now Sandoz, Inc., 588 ("Geneva") effectively delayed generic competition with the brand name drug Hytrin ${ }^{589}$ and was thus anticompetitive and a per se violation of the Sherman Act; 4) Counsel for the Plaintiff class secured a total cash settlement of $\$ 74.5$ million, ${ }^{590}$ which, according to

obtained directly by the government in this case, although state attorney general joined in the Direct Purchaser private action. In the Matter of Geneva Pharmaceuticals, Inc., Docket Nos. C-3945 and C-3946, statement of Chairman Robert Pitofsky and Commissioners Sheila F. Anthony, et. al (available at Federal Trade Commission, Bureau of Competition: Case Filings, http://ftc.gov/os/2000/05/abbottgenevastatement.htm (last updated December 14, 2001)).

587 Abbot Laboratories is based north of Chicago in Abbot Park, Illinois.

588 Sandoz, Inc. is owned by Novartis, which is based in Switzerland.

589 Hytrin is the brand name for terazosin hydrochloride, a drug used for the treatment of high blood pressure and enlargement of the prostate gland.

590 The $\$ 74.5$ million figure includes the $\$ 72.5$ million settlement between Direct Purchaser Class and Abbot and Geneva as well as a settlement with Zenith Goldline Pharmaceuticals, Inc., now known as Ivax pharmaceuticals, Inc. ("Zenith"), also named by Valley Drug it its original complaint alleging substantially similar Sherman Act violations. Zenith settled for $\$ 2,072,327$ plus interest. This settlement was finally approved by the Court on June 13, 2002 . 
plaintiffs' expert, ${ }^{591}$ is enough to reimburse a substantial percentage - $40 \%$ to $60 \%$ - of overcharges suffered by the class members while generic competition was delayed; 5) Plaintiffs' success in this litigation will discourage other brand name pharmaceutical manufacturers from unlawfully preventing or delaying generic competition, and keeping pharmaceutical drugs competitively priced is especially important because the cost of prescription drugs contributes greatly to the rising cost of healthcare; and 6) Judge Patricia A. Seitz for the Southern District of Florida awarded in awarding Counsel for the Direct Purchaser Class one third of the total recovery plus over three million dollars in expenses, Judge Patricia A. Seitz for the Southern District of Florida said that the relationship that counsel had with the class members combined with the fact that there were no objections to the settlement was "a testament to the great clientmanship that [Class Counsel] provided." ${ }^{592}$

591 Sherman Act Class Counsel's Joint Petition for Attorneys' Fees, Reimbursement of Expenses and Incentive Awards for the Named Plaintiffs and Memorandum of Points and Authorities in Support Thereof, In re Terazosin Hydrochloride Antitrust Litigation, MDL 1317 at page 15, submitted April 6, 2005 (S.D. Fla. 2005).

592 In re: Terazosin Hydrochloride Antitrust Litigation, Case No. 99-1317 MDL, Transcript of Fairness Hearing Before Hon. Patricia A. Seitz at pg 15 ln17-18, April 15, 2005. 
The $\$ 72.5$ million settlement agreement entered into on February 24, 2005 concluded over five years of litigation stemming from Abbot Laboratories" "attempts to protect its patents' exclusivity with respect to the brand name drug Hytrin, and the competing efforts of generic manufacturers to develop and launch bioequivalent drugs for entry in the terazosin hydrochloride market." ${ }^{593}$ Plaintiffs alleged that Abbot made multi-million dollar payments to generic manufacturers of the drug to delay the entry of generic versions of Hytrin to the market.

On March 30, 1998, Geneva obtained final approval from the FDA to market and sell its generic, capsule version of the drug terazosin hydrochloride, brand-name Hytrin. Two days later, April 1, 1998, Abbot entered into and agreement with Geneva. In exchange for $\$ 4.5$ million a month from Abbot, Geneva agreed not to put its generic version of Hytrin on the market, an arrangement that would continue until Abbot's patent expired or until a final judgment in the patent infringement suit that Abbot filed against Geneva regarding Geneva's tablet formulation of Hytrin. Abbot and Geneva voluntarily terminated the agreement in August 1999 after the

593 In re Terazosin Hydrochloride Antitrust Litigation, 352 F.Supp.2d 1279, 1286 (S.D. Fla. 2005). 
FTC began an investigation. ${ }^{594}$ Geneva launched its generic product on August 13, 1999. During the last five months of 1999 Geneva's generic terazosin hydrochloride had sales of $\$ 71.8$ million, an $8.8 \%$ share of the market. ${ }^{595}$

Named Plaintiffs of the Direct Purchaser Class, 596 Louisiana Wholesale Drug Co., Inc. ("LWD") and Valley Drug Co. ("Valley Drug") filed complaints against Geneva and Abbot in December 1998 and August 1999. They alleged that the agreement between Geneva and Abbot was an illegal market allocation agreement in violation of Section 1 of the Sherman Act. ${ }^{597}$

594 In the early months of 1999, the FTC launched a "probe of the drug industry's alleged efforts to block generic rivals and thus protect sales of brand-name medications." Jerry Guidera and Ralph T. King, Abbott Labs, Novartis Unit Near Pact With FTC Over Agreement on Hytrin, The Wall street Journal, Aug. 21, 1998, Pg B1.

595 Ralph T. King Jr., FTC Panel Backs Suit Against Abbot, Novartis on Deal for Hypertension Drug, The Wall street Journal, pg B20 Feb. 7, 2000.

596 In addition to the Direct Purchaser Class litigation summarized here, similar claims were pursued by individual Direct Purchasers such as Walgreens and Shop-Rite and an Indirect Purchaser classes including seventeen certified state classes of end payers for Hytrin consisting of Third Party Payers (e.g., insurance companies) and individual consumers. In re Terazosin Hydrochloride, 335 F.Supp. 2d 1336, 1342 fn 5, (S.D. Fla. 2004).

597 Valley Drug also named Zenith Goldline Pharmaceuticals, Inc., now known as Ivax pharmaceuticals, Inc. ("Zenith") in its complaint alleging substantially similar sherman Act violations. That case settled for $\$ 2,072,327$ plus interest. This settlement was finally approved by the Court on June 13, 2002 . 
Plaintiffs argued that this agreement blocked the introduction of generic versions of Hytrin, which "resulted in reduced output, artificially inflated prices, and eliminated competition in the market for terazosin hydrochloride." 598 Plaintiffs sought damages for the financial loss incurred by direct purchasers of Hytrin who paid inflated prices while entry of the generic versions of the drug was delayed by the agreement between Geneva and Abbot.

On December 13, 2000, the United States District Court for the Southern District of Florida granted Plaintiff's motion for summary judgment holding that the agreement between defendants Geneva and Abbot was a per se violation of Section 1 of the Sherman Act. The court concluded that the agreement essentially allocated the entire United States market for terazosin drugs to Abbot. ${ }^{599}$ This ruling was reversed by the $11^{\text {th }}$ circuit as "premature" and remanded to the district court to consider the exclusionary scope of the patent before making any determination. ${ }^{600}$ On January 5, 2005, the district court

598 In re Terazosin Hydrochloride Antitrust Litigation, 352 F.Supp. 2d at 1287 .

599 Id. at 1292 .

600 Valley Drug Co. V. Geneva Pharms., Inc., 344 F.3d 1294, 1304 (11 th Cir. 2003). In reversing the District Court's Ruling, the Eleventh Circuit explicitly rejected the reasoning of the Sixth Circuit in In re Cardizem CD, $332 \mathrm{~F} .3 \mathrm{~d}$ 
ruled on multiple motions for summary judgment filed by parties on both sides of the litigation. The district court again granted Plaintiffs' motion for summary judgment on this issue holding that the agreement exceeded the exclusionary rights Abbot enjoyed as a result of the patent it held on terazosin hydrochloride not due to expire until 2014 and that in light of this, the agreement was indeed a per se violation of section 1 of the Sherman Act. The Direct Purchaser Class settled with Geneva and Abbot for $\$ 72.5$ million the following month.

Class Counsel spent more than 51,000 hours over the course of six years litigating this case, not including the pre-complaint investigation. The litigation involved obtaining admissible testimony from witnesses, working with experts, conducting market research and analysis, several rounds of motions for summary judgment and class certification and a

$896\left(6^{\text {th }}\right.$ Cir. 2003). In Cardizem, the court held that a similar agreement was a per se violation of the Sherman Act, adding that "[i]t is one thing to take advantage of a monopoly that naturally arises from a patent, but another thing altogether to bolster the patent's effectiveness in inhibiting competition by paying the only potential competitor $\$ 40$ million per year to stay out of the market.") Id. at 908. In Valley Drug, the Eleventh Circuit responded that "[w] hen the exclusionary power of a patent is implicated, however, the antitrust analysis cannot ignore the scope of the patent exclusion." Valley Drug, 344 F.3d at 1311. However, not withstanding the Valley Drug opinion, on remand the District Court did find the agreement to be a per se violation. In re Terazosin Hydrochloride, 352 F.Supp 2d. 1279 (S.D. Fla. 2005). 
complex and protracted discovery process. Class Counsel's significant investment of time and resources resulted in a substantial settlement - 40\% to $60 \%$ of the direct purchasers' total loss ${ }^{601}$ - on February 24, 2005. The court granted Class Counsel their requested fees in the amount of one third of the settlement proceeds, plus interest and $\$ 3,133,070.86$ in expenses. ${ }^{602}$ The remaining settlement funds will be distributed pro-rata, reimbursing class members ${ }^{603}$ for the difference between the price they actually paid for terazosin

601 Sherman Act Class Counsel's Joint Petition for Attorneys' Fees, Reimbursement of Expenses and Incentive Awards for the Named Plaintiffs and Memorandum of Points and Authorities in Support Thereof, In re Terazosin Hydrochloride Antitrust Litigation, MDL 1317 at page 15, submitted April 6, 2005 (S.D.Fla. 2005).

602 Including the Zenith settlement, supra $n$. 5, for $\$ 2,072,327$ the total recovery in this litigation was $\$ 74,572,327$. The proceeds of the Zenith settlement are being applied to the reimbursement of out-of-pocket expenses only. Class Counsel are not seeking attorney's fees from the Zenith settlement. The Judge also approved incentive awards for the named plaintiffs "[i]n light of their six years of service on behalf of the class." In re Terazosin Hydrochloride Antitrust Litigation, Case No. 99-1317 MDL, Order and Final Judgment, pg 11, In 27, Apr. 19, 2005. Louisiana Wholesale Drug Co., Inc. was awarded $\$ 45,000$ and Valley Drug Co. was awarded $\$ 30,000$. Id.

603 Ultimately the class was defined as all purchasers of both brand name and generic drugs who also purchased terazosin hydrochloride directly from Abbot at any time during the period commencing March 31, 1998 when Geneva obtained FDA approval to sell its generic version of terazosin hydrochloride until the illegal agreements were terminated on August 13,1999. 
during the period that generic competition was illegally delayed and the price they would have paid if a generic version of the drug was available. District Court Judge Patricia A. Seitz approved the final settlement on April 15, 2005 noting the quality of the advocacy and that "this is a case in which I think justice was accomplished by a settlement" ${ }^{604}$ and said that the relationship that counsel had with the class members combined with the fact that there were no objections to the settlement was "a testament to the great clientmanship that [Class Counsel] provided." 605

In addition to obtaining a substantial monetary award for direct purchasers who overpaid for terazosin hydrochloride, Plaintiffs' success in this litigation will benefit consumers in the future. In particular, the district court's determination, on remand, that the agreement between Abbot and Geneva was a per se violation of the Sherman Act will discourage other brand name drug manufacturers from using such agreements to delay or prevent generic competition, helping to reduce national healthcare costs by keeping prescription drugs competitively priced.

604 In re Terazosin Hydrochloride Antitrust Litigation, Case No. 99-1317 MDL, Transcript of Fairness Hearing Before Hon. Patricia A. Seitz at pg 15 ln 6-7, April 15, 2005.

605 In re Terazosin Hydrochloride Antitrust Litigation, Case No. 99-1317 MDL, Transcript of Fairness Hearing Before Hon. Patricia A. Seitz at pg 15 ln17-18, April 15, 2005. 
Transamerican Refining Corp. V. Dravo Corp., et al., No. 4:88CV00789 (Docket) (S.D.Tex. Mar. 10, 1988) (Specialty Steel Piping Antitrust Litigation) (1992 settlement)

Summary: This case is noteworthy because: 1) It resulted in a $\$ 50$ million settlement in $1992 ; 2)$ The Court awarded $30 \%$ attorney's fees; 3) All of the overcharged victims were American businesses; and 4) The private action was a follow-up to a federal enforcement action that involved a large nationwide class action slightly broader in its scope than the federal suits that were brought. ${ }^{606}$

This litigation began as a result of a task force that the federal government appointed to investigate the sale of pipe to the Washington Public Power Supply System ("WPPSS") in Seattle. ${ }^{607}$ Apparently this investigation was sparked by the closing of several public power projects. Numerous suits involving securities fraud and contract matters were filed

606 The private action spanned a time frame of 1966-1985. The federal cases alleged activity no earlier than 1974 and no later than 1987, with many cases spanning only a few years Aff. Of Lynn Lincoln Sarko in Support of Pls' Mot. For Class Cert. Re: Summary of Crim. Procs. Ex. 2. Parallel Crim. Procs. In Re Spec. Steel Antitrust Litig. Pgs. 1-5. Transamerican Refining Corp., et. al. v. Dravo Corp., et. al., No. 4:88CV00789 (Docket) (S.D.Tex. Mar. 10, 1988) (Specialty steel Piping Antitrust Litigation).

607 Dravo and others Settle Pipe Price-Fixing Suit, 228 ENGR. NEWS-RECORD 14 (Apr. 6, 1992) (Available in 1992 WLNR 1682774). 
against the WPPSS due to the failure of these nuclear power projects. There was much public interest in their completion because it was hoped that they would provide an economical energy supply to Washington residents. ${ }^{608}$

As a result, a price-fixing scheme was uncovered by the WPPSS Task Force of the Justice Department, the Internal Revenue Service and the Federal Bureau of Investigation. ${ }^{609}$ From 1986-1988, numerous corporations and their officers were criminally charged with price fixing schemes. The alleged mastermind, Gerald Profita, president and CEO of Shaw Corporation, Inc., plead guilty and received a jail sentence of eight years plus a $\$ 25,000$ fine. ${ }^{610}$

608 Per telephone conversation with Mark Griffin, Esq, Partner at Keller Rohrback in Seattle, Washtington. He was a co-lead in the specialty steel Piping Antitrust Litigation.

609 Dravo and others Settle Pipe Price-Fixing Suit, 228 ENGR. NEWS-RECORD 14 (Apr. 6, 1992) (Available in 1992 WLNR 1682774).

610 Aff. Of Lynn Lincoln Sarko in Support of Pls' Mot. For Class Cert. Re: Summary of Crim. Procs. Ex. 2. Parallel Crim. Procs. In Re Spec. Steel Antitrust Litig. Pgs. 1-5. Transamerican, No. 4:88CV00789 (Docket) (S.D.Tex. Mar. 10, 1988) (Specialty Steel Piping Antitrust Litigation). The government's "star" witness, Shaw Co.'s manager of purchasing from 1976-1985, W. Robert Short, was found guilty of violating the Sherman Act and received a jail sentence of three years plus a fine of $\$ 11,000$. Id. at Pg 21,22. Two other main participants included the president and vice president of Standard Pipe \& Supply Company Inc., Daniel Petrone and Allan Miller. Both plead guilty and received a jail sentence of two 
This suit, filed on March 10, 1988, arose out of an alleged conspiracy to illegally fix the price of specialty steel piping materials sold under cost-plus arrangements throughout the United States between 1966 and 1985. ${ }^{611}$ The class of Plaintiffs, numbering approximately 6,000, consisted of refineries, and other buyers who purchased the specialty steel piping material on a cost-plus basis. There were thirty one defendants representing the sellers of the specialty steel piping material. ${ }^{612}$ Plaintiffs' counsel successfully defeated several motions to dismiss based on plaintiffs' failure to state a claim upon which relief can be granted and lack of proper pendent jurisdiction. ${ }^{613}$

years each. Id. Many others received lesser prison sentences and fines. Id.

611 "The manufacturers or distributors, as suppliers of specialty steel piping, allegedly made arrangements with pipe fabricators to quote an inflated price on steel which was to be resold by the pipe fabricators on a cost-plus basis. It is alleged that the supplier and fabricator later divided the price differential through payments or credits." Transamerican Refining Corp., et al. v. Dravo Corp., et al. Available in 1990 WL 122228, 1990-2 Trade Cases P 69, 127,1 (S.D.Tex. June 22, 1990) (No.CIV. A. H-88-789). "Some defendants allegedly marked up the cost of the pipe by about 25\% and kicked back a portion to the fabricators", said Lynn L. Sarko, an attorney for the plaintiffs. Dravo and others settle Pipe Price-Fixing Suit, 228 ENGR. NEWS-RECORD 14 (Apr. 6, 1992) (Available in 1992 WLNR 1682774 ).

612 Id.

613 Transamerican, Available in 1990 WL 122228, 1990-2 Trade Cases P 69, 127 (S.D.Tex. June 22, 1990) and Transamerican 
The case settled in 1992 for about $\$ 50$ million. ${ }^{614}$

Attorneys fees of $30 \%$ were awarded Plaintiffs' counsel in addition to reimbursement of costs. ${ }^{615}$

Refining Corp., et al. v. Dravo Corp., et al. Available in 1991 WL 261765, (S.D.Tex. Oct. 29, 1991) (No.CIV.A.H-88-789). 614 of the thirty one defendants, Allied Signal, Inc. paid the largest single settlement of $\$ 14,000,000.00$ Adam Goodman, LaBarge Settles Antitrust Case, ST. LOUIS POSTDISPATCH (SAT. FIVE-STAR ED.) 9C (Aug. 8, 1992) (Available in 1992 WLNR 509337). 614 See attached in its entirety as Exhibit 1 the Notice of Class Notice and Proposed Partial settles., Attachment A. Transamerican, No. 4:88CV00789 (Docket) (S.D.Tex. Mar.10,1988) (Specialty Steel Piping Antitrust Litigation). Pullman Power Products and Resco Holdings Inc., paid 7,300,000.00. See attached in its entirety as Exhibit 2 the Notice of Hearing on Proposed Partial settles. of Class Actions and Application for Interim Award of Counsel Fees and Expenses, Attachment A. Transamerican, No.

4:88CV00789 (Docket) (S.D.Tex. Mar.10,1988) (Specialty Steel Piping Antitrust Litigation) as Exhibit 2. Dravo settled the suit for $\$ 6,000,000.00$. Id. Crane Company was one of the last defendants to settle for $\$ 5,300,000.00$. See attached in its entirety as Exhibit 3 the Notice of Hearing on Proposed Partial settle. of Class Actions; Application for Award of Counsel Fees and Expenses; Proposed Plan of Distrib; Verified Proof of Claim Form; and Claim Proc. at 2 .

615 Id. at 3. . Transamerican, No. 4:88CV00789 (Docket)

(S.D.Tex. Mar.10,1988) (Specialty Steel Piping Antitrust Litigation). 
In re: Urethane Antitrust Litigation, MDL No. 1616, 232 F.R.D. 681 (D. Kan. 2005).

Summary: The urethane litigation is noteworthy because: 1) It started when the DOJ discovered a conspiracy involving polyester polyols (Chemical 1), for which defendants paid a criminal fine; 2) Counsel for the direct purchaser class filed a follow-on suit, involving a longer conspiracy period, which secured an \$18 million settlement from one defendant, Bayer. The case against the other defendant is still pending; 3) While pursuing the case against Chemical 1, plaintiffs' counsel brought suit alleging another conspiracy involving a related chemical, polyether polyols (Chemical 2); 4) Plaintiffs in the Chemical 2 class action, again the direct purchasers, secured a $\$ 55.3$ million settlement from one defendant, Bayer, and the cases against the other defendants are still pending; and 5) Both settlements received so far, $\$ 73.3$ million, were from the wholly owned subsidiary of a foreign corporation.

Polyurethane (urethane) is an elastic type of rubber produced by either a polyester polyol (Chemical 1) or a polyether polyol (Chemical 2). ${ }^{616}$ The Chemical 1 case began

616 Polyester polyols "are used to manufacture a variety of foam-based products such as packaging, automobile air filters, sound-deadening materials, and furniture as well as non-foam products such as certain coatings and adhesives." In re Urethane Antitrust Litig., 237 F.R.D. 440, 443 (D. Kan. Aug. 
after a U.S. government investigation revealed an unlawful price-fixing conspiracy between Bayer Corp., a U.S. subsidiary of Bayer AG, and Crompton Corp., now known as Chemtura Corp. ${ }^{617}$ In March 2004, Crompton issued a press release stating that it was being granted amnesty for participating in the investigation. ${ }^{618}$ Nearly a month later, a private follow-on case ensued, as the first Chemical 1 case was brought by direct purchasers. ${ }^{619}$ In August 2004, the U.S. District Court for the District of Kansas consolidated the Chemical 1 cases into the In re Urethane Antitrust Litigation. Plaintiffs alleged that Bayer and Crompton fixed prices between January 1, 1998 and December 31, 2004 .

The Chemical 2 case arose out of an investigation by a private law firm in Fall 2003, which was actually before any of the Chemical 1 cases were filed. Apparently, the private

16, 2006). Polyether polyols are softer and more elastic, and are usually used to make spandex and soft rubber parts.

${ }^{617}$ Bayer Unit to Pay $\$ 33 \mathrm{MIn}$ Fine, Plead to Price Fixing; see <http://www. cbgnetwork.org/296.html (Sept. 30, 2004) >.

618 Crompton Corp., Crompton Announces Agreements in U.S. and Canadian Rubber Chemicals Investigations, BusinessWire (2004); see <http://phx. corporate-ir.net/phoenix.zhtml?c= $68079 \& \mathrm{p}=\mathrm{irol}$-newsArticle_Print\&ID=547653\&highlight $=>$.

619 Per telephone conversation with Christopher J. Cormier, Esq., of Cohen, Milstein, Hausfeld \& Toll, P.L.L.C. in Washington, D.C (Jan. 12, 2007). This law firm is co-lead counsel in the Chemical 2 cases. 
plaintiffs wanted to see if either the investigation or lawsuit involving Chemical 1 would include Chemical 2 . When they saw that it did not, then they chose to pursue the Chemical 2 case. ${ }^{620}$ The named defendants in this suit are Bayer, BASF, The Dow Chemical Company, Lyondell Chemical Company, and Huntsman International LLC. These defendants control $75 \%$ of the Chemical 2 market and $100 \%$ of two other markets closely related to Chemical $2 .{ }^{621}$

The suit alleges that these defendants consistently announced and implemented price increases at the same or similar times between January 1, 1999 and December 31, 2004, and the complaint offered four specific periods describing in detail each defendant's involvement. ${ }^{622}$ Plaintiffs allege that these price increases cannot be explained by changes in the price of raw materials or by changes in demand, and that the defendants participated in secret meetings and conversations during which they agreed to fix prices and allocate

${ }^{620} \mathrm{Pl}$. Coordination Req. at 4-5, In re Urethane Antitrust Litig., 237 F.R.D. 440 (D. Kan. August 22, 2005).

621 These markets are the methylene dyphenyldiisocyanate (MDI) and toluene diisocyanate (TDI) markets.

${ }^{622}$ In re Urethane Antitrust Litig., 409 F. Supp. 2d 1275, 1280 (D. Kan. Jan. 18, 2006). 
customers. ${ }^{623}$ In June 2005, these cases were coordinated with the Chemical 1 cases. ${ }^{624}$

On september 30,2004 , Bayer agreed to plead guilty to charges of participating in a criminal conspiracy to fix Chemical 1 prices between 1998 and 2002, and to pay a criminal fine of $\$ 33$ million. Note that the private suit alleged overcharges between 1998 and 2004, which encompassed two years more than the government suit. ${ }^{625}$

The government began an investigation on Chemical 2 price-fixing in February 2006. Defendants of the private suit were issued subpoenas from the DOJ seeking information relating to the manufacture and sale of Chemical 2, MDI and TDI. Because of the timing of the investigation, we believe that it stemmed from the private suit.

In August and October 2006, the court approved settlements with Bayer releasing the company from liability in the two private suits. Bayer agreed to pay $\$ 55.3$ million to

623 Id. at 1279 .

624 Because of the arguably differing nature between the Chemical 1 and Chemical 2, the court elected not to consolidate the two groups of cases, but rather consolidate each individually, and the two sets of cases would proceed on separate tracks for scheduling purposes.

625 Notice of Class Action Settle. with Bayer and Fairness Hrg. at 1, In re Urethane Antitrust Litig., 237 F.R.D. 440 (D. Kan. June 13,2006 ). 
Chemical 2 plaintiffs, and $\$ 18$ million to Chemical 1

plaintiffs. These have been the only settlements thus far, and the cases against the other defendants are still ongoing. ${ }^{626}$

In granting preliminary approval of the Bayer settlement for Chemical 2, the Honorable John W. Lungstrom praised the private plaintiffs" attorneys, stating that "these law firms have performed extensive work identifying and investigating the potential claims in this action, have ample experience handling cases similar to this one, have demonstrated adequate knowledge of the applicable law, will devote adequate resources to representing the class, and have done a commendable job thus far prosecuting the polyether polyol plaintiffs' claims."627 Attorneys' fees have not been awarded yet for either case. ${ }^{628}$

626 The Chemical 1 cases have finished class discovery and are currently in merits discovery. The Chemical 2 cases are still in class discovery. Per e-mail conversation with Christopher J. Cormier, Esq., of Cohen, Milstein, Hausfeld \& Toll, P.L.L.C. in Washington, D.C (Dec. 28, 2006).

627 T.R.O. Hrg. Transcr. at 18, In re Urethane Antitrust Litigation, 237 F.R.D. 440 (D. Kan. March 27, 2006).

${ }^{628}$ Per e-mail conversation with Christopher J. Cormier, Esq., of Cohen, Milstein, Hausfeld \& Toll, P.L.L.C. in Washington, D.C (Dec. 28, 2006). 
In Re: Visa Check/MasterMoney Antitrust Litigation, a/k/a WalMart Stores, Inc. et. al V. Visa U.S.A. Inc. and MasterCard International Inc., 396 F. 3d 96, 114 (2d Cir. 2005).

Summary: This case is unusually noteworthy because: 1 . It resulted in payments to victims that had a present value of $\$ 3.383$ billion in cash, the largest settlement in antitrust history (in fact, it was "the largest settlement ever approved by a federal court" $\left.{ }^{629}.\right) ; 2$. It also resulted in significant injunctive relief that the court valued at "\$25 to \$87 billion or more" ${ }^{630} ; 3$. It did not involve a classic "hard core" conspiracy, but rather involved a number of complex section 1 and Section 2 allegations; and 4. The awarded attorneys fees were only $6.5 \%$ of the monetary recovery, and were far less than $1 \%$ of the total value that the court ascribed to the combination of the monetary recovery and injunctive relief. ${ }^{631}$

On October 25, 1996, a class of approximately 5 million merchants, including Wal-Mart, Sears, and Safeway, sued Visa and MasterCard for alleged violations of Sections 1 and 2 of the Sherman Act. "First, plaintiffs claimed that the

629 See In re Visa Check/Mastermoney Antitrust Litigation, 297 F. Supp. 2d 503, 511 (E.D.N.Y. 2003).

630 Id.

631 See Wal-Mart Stores, Inc. et. al., V Visa USA \& MasterCard International, 396 F. 3d 96, 114 (2d Cir. 2005). 
defendants' 'Honor All Cards' policy, which forced merchants who accepted Visa and MasterCard credit cards to accept Visa and MasterCard debit cards, was an illegal 'tying arrangement' that violated Section One of the Sherman Act. Second, plaintiffs alleged that defendants used their Honor All Cards policy in conjunction with other anti-competitive conduct to monopolize the debit card market, in violation of section Two of the Sherman Act. As a consequence, plaintiffs claimed that they incurred supra-competitive 'interchange fees' ... during every debit and credit transaction made between October 1992 and June 2003."632

Although the DOJ began its preliminary investigation into antitrust violations by Visa and MasterCard in December of 1993,633 that investigation focused primarily on alleged duality and exclusionary conduct, resulting in the U.S. v. Visa litigation. That case established the relevant market, but as the district court noted, the Plaintiffs here "did not benefit from any previous or simultaneous government litigation...."634 Instead, "the Government piggybacked off of

632 Id. at 100

${ }^{633}$ U.S. v. Visa, Civil Action No. 98-7076 (BSJ) (S.D.N.Y.), Declaration of Mary Jean Moltenbrey, available at http://www.usdoj.gov/atr/cases/f2100/2188.pdf.

${ }^{634}$ In re Visa Check/Mastermoney Antitrust Litigation, 297 F.Supp.2d at 523. 
plaintiffs' counsel's work,"635 filing a motion to participate in the distribution of the private settlement. Moreover, class counsel petitioned the FTC, numerous state Attorneys General, and the DOJ to enjoin the conduct alleged in Plaintiffs" Complaint, which "contributed to the filing of the [DOJ's] suit against Visa and MasterCard roughly two years after In re Visa Check was initiated." ${ }^{636}$

The litigation was complex and lasted for years. During proceedings spanning almost a decade, more than 400 lawyers and paralegals, led by Constantine, Cannon, P.C., litigated on behalf of plaintiffs, obtaining class certification, winning a motion for summary judgment and defeating defendants' motion for summary judgment. The parties settled on the eve of trial. "Counsel for the class took and defended approximately 400 depositions, including 21 expert depositions, and reviewed more than 5 million pages of documents..." ${ }^{637}$ The quantity and quality of this effort, the difficulty of the legal issues involved, and the spectacular results obtained, underlay the

${ }^{635}$ Wal-Mart Stores, Inc. et. al., V Visa USA \& MasterCard International, 396 F.3d at 122 .

${ }^{636}$ Id., Brief of Appellees/Class Representatives in Response to Brief of Appellant Nucity Publications, Inc. at 11.

637 Wal-Mart Stores, Inc. et. al., V Visa USA \& MasterCard International, 396 F.3d at 111. 
Court's decision to award $\$ 220$ million in legal fees (the above-mentioned $6.5 \%$ of the monetary recovery alone).${ }^{638}$

The case was settled in April 2003 for " $\$ 3.383,400,000$ in compensatory relief, plus additional injunctive relief valued at $\$ 25$ to $\$ 87$ billion or more." ${ }^{639}$ Under the terms of the settlement, Visa will pay slightly more than \$2 billion to the merchants and MasterCard will pay slightly more than \$1 billion. Both firms also agreed to implement a wide variety of injunctive relief. For example, they agreed to significantly lower their charges for debit transactions on August 1, 2003. This saved merchants more than \$1 billion from August 2003 to April 2004 alone. On January 1, 2004, merchants in the United States gained the freedom to choose to accept Visa and MasterCard debit products based upon their quality, speed, safety and price. They are no longer forced by the associations' rules to accept debit cards if they take credit cards. Not surprisingly, the District Court judge in the case characterized the injunctive relief as of "substantial" value. ${ }^{640}$

\footnotetext{
638 Id. at 114

639 Id. at 111

640 See In re Visa Check/Mastermoney Antitrust Litigation, 297 F. Supp. 2d 503, 525 (E.D.N.Y. 2003).
} 
Judge John Gleeson granted final approval of the settlements and the plan of allocation on December 19, 2003. The United States Court of Appeals affirmed this decision on January 4, 2005. Distributions to class member merchants from the settlement fund will be made soon.

In re Vitamins Antitrust Litigation (many related cases)

This series of more than 100 related cases is historic because: 1. Settlements in total resulted in approximately 
$\$ 4.2$ to $\$ 5.6$ billion being returned to overcharged U.S. purchasers of vitamins and related products ${ }^{641}$, the largest total for any related series of antitrust cases in history; 2 . Of this, between $\$ 3.7$ billion and $\$ 5.1$ billion was returned to direct purchasers; 3 . Of this total, an additional \$500 million was returned to indirect purchasers; 4. Almost all of the private vitamins cases settled. A jury in the only vitamins case that went to verdict, a separate conspiracy involving choline chloride, decided that the cartel had overcharged purchasers by approximately $\$ 49.5$ million, e.g. a 61\% price rise; 5 . It has been estimated that on average prices increased by approximately $15 \%$ to $80 \%$ for the 16 different vitamins that were cartelized, with an average overcharge of $43.7 \%$. Of the amounts paid to U.S. purchasers, more than $99 \%$, or $\$ 4.2$ to $\$ 5.6$ billion, was paid by foreign cartel members; 7 . Although the precise sequence of events is not without controversy, it appears that much and perhaps all of the crucial original discovery of the illegal behavior was made by private counsel; 8 . These cases also resulted in criminal fines of approximately $\$ 915$ million by the U.S. enforcers and approximately $\$ 946$ million by the

641 Unless noted, all of the empirical estimates in this Section are from John M. Connor, "The Great Global Vitamins Conspiracy: Sanctions and Deterrence," Draft of 2/14/06, available at www.antitrustinstitute.org 
European Union and other foreign enforcers; 9. A number of defendants went to jail; 10. Because of the huge number of separate vitamins cases, we are not able to estimate precisely the average percentage of the refunds that went to class counsel in the form of legal fees. However, one source estimates that on average the legal fees were no more than $10 \%$ of the settlements, while another source lists the percentage for the indirect purchaser cases at $14 \%$

It is difficult to determine the exact origin of these cases: who first discovered the first evidence of, or enough hard evidence to prove the existence of, the vitamins cartels ${ }^{642}$. Cause-and effect is especially difficult to determine because the "vitamins cartels" actually consisted of 16 different cartels with partially overlapping memberships that, generally speaking, fell into two major groups. Some of the earliest indications that one or more vitamins markets might have been cartelized, moreover, did not seem fruitful and were not pursued vigorously by the government enforcers, but were later re-opened and pursued and led to strong evidence of collusion.

642 We attempted to find an public account of the origin of the vitamins cases that written by the Department of Justice Antitrust Division but could not. When we sent them the version contained in this document they would not comment on its accuracy or completeness. 
David Boies relates that one of his partners uncovered evidence that Roche was discussing prices with its competitors. ${ }^{643}$ Boies and his colleagues investigated, and by May 1997 had found evidence consistent with collusion. They then found more evidence, and by December 1997 decided they had enough to file suit. But first they gave their information to the Antitrust Division. Boies says that his firm uncovered and ultimately proved the collusion "without the benefit of government involvement."644 Professor John Connor presents a more complicated analysis of the events, but ultimately also gives these private counsel credit for uncovering the first solid evidence of collusion. ${ }^{645}$ As will

643 David Boies, Courting Justice (2004) at 226-30. Another source said this evidence was uncovered while he was in the course of preparing a patent-infringement suit. John M Connor, "The Great Global Vitamins Conspiracy: Sanctions and Deterrence," Draft of 2/14/06, at 26, available at www .antitrustinstitute.org

644 David Boies, Courting Justice (2004) at 230.

645 "U.S. investigators first got wind of the vitamins cartel and Roche's role in it in late 1996 from sources at ADM cooperating with the DOJ in its investigation of the citric acid cartel ..." As a result the FBI interviewed Dr. Kumo Sommer, the head of Roche's Vitamins division, in March 1997. "Sommer denied the existence of any vitamins cartel and the DOJ apparently decided to wind down its investigation for the meanwhile... However, in] "late 1997 a partner of the law firm of Boies \& Schiller...." presented the DOJ with evidence that a conspiracy was occurring. John M Connor, "The Great Global Vitamins Conspiracy: Sanctions and Deterrence," Draft of 2/14/06, at 25-26, available at www.antitrustinstitute.org 
be seen infra, this perspective is confirmed by the defendants themselves. However, many of the details of the Department of Justice investigation are non-public, and it is clear that both private counsel and the U.S. Department of Justice were on parallel tracks and discovered much of the critical evidence at around the same time, and that the investigation of each helped that of the other.

Class counsel filed the first Vitamins Complaint in March 1998, on behalf of a class of direct purchasers. They alleged that as early as 1990 and continuing into 1998, Defendants ${ }^{646}$ conspired to fix prices, allocate markets, and engage in other collusive conduct with respect to certain vitamins, vitamin premixes and other bulk vitamin products. ${ }^{647}$

Following this complaint, the full dimensions of the Defendants' conspiratorial conduct began to become known. In March 1999, the Antitrust Division of the United States Department of Justice announced that Defendant Lonza AG had pleaded guilty to violating section 1 of the Sherman Act for

646 The defendants were F. Hoffman-La Roche, Ltd., Hoffman-La Roche, Inc., Rhone-Poulenc S.A., Rhodia, Inc., BASF AG, and BASF Corporation.

647 Class Counsel uncovered Defendants' illegal conspiratorial conduct before any grand jury investigation became public, before guilty pleas began to be entered in 1999, before federal cooperation agreements became public, and before any Defendant confessed to any wrongdoing. 
fixing the price of vitamin B3 (niacin), and that Defendant Chinook Group Ltd., certain of its executives and certain executives of non-settling Defendant DuCoa, LP, had pleaded guilty to violating section 1 for fixing the price of vitamin B4 (choline chloride). ${ }^{648}$

It is clear that Class Counsel significantly contributed to the discovery of this illegal activity. At the May 21, 1999 press conference in Basel, Switzerland announcing the Roche guilty pleas, Hoffman-La Roche's CEO, Franz Humer, explained how it was the early 1998 class action lawsuit (and not a government investigation) that prompted a new internal investigation that caused Roche to terminate its conspiratorial conduct and begin to cooperate with the government:

In 1997, responding to the settlement in the citric acid case and to the news of an investigation of the bulk vitamins industry, Roche initiated an internal inquiry of its own, which at the time did not turn any evidence of wrongdoing. A second internal inquiry prompted by class action lawsuits filed against Roche and other companies in early 1998 for alleged price-fixing in the bulk vitamins market revealed that further action was needed. The inquiry was carried out in collaboration with US experts. Internal measures were implemented without delay to ensure an immediate halt to any antitrust violations. The findings from

648 Two months later, Defendant F. Hoffman-La Roche Ltd. pled guilty and BASF AG agreed to plead guilty to fixing the prices of various vitamins products. 
this second inquiry formed the basis for Roche's decision to offer, on 1 March this year, its full cooperation in the US Justice Department investigation. ${ }^{649}$

As part of the cooperation prompted by lawsuits filed by Class Counsel, Roche employees interviewed by the U.D.

Department of Justice implicated other conspiracy participants - including several of the Settling Vitamin Products Defendants - and provided substantial information about the duration and scope of the price-fixing conspiracy. The facts detailed in these interviews regarding conspiratorial conduct in the vitamins industry were subsequently relied on by Roche in preparing its written Fed. R. Civ. P. Rule 30 (b) (6) statement, which described Roche's view of the scope of the conspiracy. ${ }^{650}$ Roche's Rule 30 (b) (6) statement, which implicated other conspirators, placed substantial settlement pressure on the Settling Vitamin Products Defendants.

649 See Exh. 9 to Class Plaintiffs' Memorandum in support of Motion for Preliminary Approval of Niacin and Biotin Defendants, at 3 .

650 As described by the Special Master, the Roche Rule 30 (b) (6) statement "at 101 pages, the longest of the statements, contains charts listing the date and location of events or meetings for particular vitamins, participants and the companies they represented, the vitamins products discussed, and additional details about the meetings." Special Master's Report \& Recommendation, dated August 8 , 2002, at 11. [Verilaw No. 11362.) 
During this period, as a result of additional

investigation and discovery, Class Counsel added several

Defendants to the all-vitamins Complaint, ${ }^{651}$ and also filed a separate complaint that alleged a conspiracy relating only to choline chloride. ${ }^{652}$ These and subsequent complaints have resulted in a large number of settlements. ${ }^{653}$ Plaintiffs also pursued their investigation of price-fixing ${ }^{654}$ in the choline

651 These defendants included Hoechst Marion Roussel; Takeda Industries, Ltd., Takeda Vitamin \& Food USA, Inc., and Takeda U.S.A., Inc.; Eisai Co., Ltd., Eisai U.S.A., Inc., and Eisai Inc.; Daiichi Pharmaceuticals Co., Ltd., Daiichi Fine Chemicals, Inc., and Daiichi Pharmaceuticals Corporation; Merck KGaA and EM Industries, Inc.; Sumitomo Chemical Co., Ltd. and Sumitomo Chemical America, Inc.; Tanabe Seiyaku Co., Ltd. and Tanabe USA, Inc. (Sumitomo and Tanabe are referred to collectively as the "Biotin Defendants"); Reilly Industries, Inc. and Reilly Chemicals, S.A.; Lonza Group Ltd., Lonza Inc. and Lonza AG; Degussa AG and Degussa Corp.; and Nepera, Inc. (Lonza, Degussa, Nepera and Reilly are referred to collectively as the "Niacin Defendants").

652 They named as Defendants Akzo; UCB Chemicals; Chinook Group, Ltd., Chinook Group, Inc., and Cope Investments, Ltd.; Bioproducts, Inc. (United States company), Mitsui \& Co. U.S.A., Inc., and Mitsui \& Co. Ltd.; and various individual Defendants.

653 For example, on November 3, 1999, Class Plaintiffs reached a settlement with the Hoffman-La Roche, BASF, Rhone-Poulenc, Hoechst, Takeda, Eisai and Daiichi Defendants regarding those Defendants' sales of bulk vitamin products, and with the BASF Defendants regarding their sales of Choline Chloride (the "Initial settlement"). See In re Vitamins Antitrust Litig., Misc. No. 99-197, 2000 U.S. Dist. LEXIS 8931 (D.D.C. Mar. 31, $2000)$, at $* 16$

654 These settlements and agreements followed and preceded several guilty pleas with government authorities. For example, on March 1, 1999, DuCoa/DCV employees Lindell 
chloride industry, settled with some defendants, and reached cooperation agreements with most individual Defendants. Two defendant groups did not settle, however, and this case went to verdict. The jury found that the Mitsui Defendants and the DuCoa/DCV Defendants conspired to fix the price of choline chloride (vitamin B4). The jury also found that Class Plaintiffs had been damaged in the amount of $\$ 49,539,234$ (before trebling). ${ }^{655}$ After the trial, Class Plaintifs settled

Hilling, John "Pete" Fischer, and Antonio Felix, and Chinook employees John Kennedy (formerly of Bioproducts) and Robert Samuelson pled guilty to price fixing and market allocation of choline chloride. On May 20, 1999, BASF AG pled guilty in the United states to price fixing and market allocation of certain vitamins, and on september 17, 1999, BASF AG pled guilty in Canada to price fixing and market allocation of choline chloride.

655 On the first day of the choline chloride trial (In re Vitamins Antitrust Litigation -- Animal Science Products, Inc., et al. v. Chinook Group, Ltd., et al.) between Class Plaintiffs and the Mitsui and DuCoa/DCV Defendants, Chief Judge Thomas Hogan stated in his opening remarks to the jury pool that:

"[T]his is a very challenging and interesting case involving what we call antitrust issues between the parties. That's anticompetitive-type business issues involving, I think, some of the finest business litigating lawyers or litigation-type lawyers in the country that are before you that you will have the privilege to listen to." May 28, 2003 Trial Tr. at 25:16 .

After the jury returned a verdict of $\$ 49.5$ million in damages for the Class Plaintiffs, Chief Judge Hogan thanked the jurors for their service and stated:

"[T]his is a serious case, and you had the pleasure of having very excellent lawyers on both sides appear before you." June 
with the Mitsui Defendants for an amount greater than the verdict and presently are engaged in post-judgment discovery with the DuCoa and DCV Defendants.

Professor Connor estimates that on average the attorneys received no more than $10 \%$ of the settlements in the form of attorneys fees. ${ }^{656}$ A survey of 24 indirect purchaser class action cases found that in all 24 cases the attorneys were awarded a $14 \%$ fee, in addition to the total of $\$ 267$ million that was returned to overcharged purchasers. ${ }^{657}$ We have heard anecdotes of fees in particular vitamins cases as high as 33\%, however, but are aware of no other average figures.

13, 2003 Trial Tr. at 1520:8-10.

656 John M. Connor, "The Great Global Vitamins Conspiracy: Sanctions and Deterrence," Draft of 2/14/06, available at www.antitrustinstitute.org

657 See Settlements of Indirect Purchaser Class Actions Under State Law - September 30, 2005, submitted by Patrick E. Cafferty to the Antitrust Modernization Commission. 